\title{
El desarrollo humano integral. Horizonte de formación por capacidades y competencias. La gestión del proyecto institucional universitario*
}

\section{Integral human development: Education horizon for skills and competences. Management of the institutional university project}

\author{
Guillermo León Villa Hincapié \\ Magíster en Administración Educativa Énfasis Dirección, \\ Magíster en Evaluación Educativa. \\ Candidato a Ph. en Educación Universidad de Costa Rica. \\ Correo electrónico: villahincapie@yahoo.es
}

Recibido: 16 de marzo de 2016; aprobado: 12 de mayo de 2016

\section{Cómo citar este artículo:}

Villa, G.L. (2016). El desarrollo humano integral. Horizonte de formación por capacidades y competencias. La gestión del proyecto institucional universitario. Espiral, Revista de Docencia e Investigación, 6(1), 9 - 58.

\section{Resumen}

Objetivo. En este artículo se esbozan y dialogan las inquietudes e interpretaciones que en la praxis comunicativa cotidiana emergen acerca de la crisis de la universidad, de sus efectos en la sociedad, y de las posibles alternativas de solución, desde el horizonte amplio de las humanidades, y no solo desde lo que conviene a la ciencia, a la técnica o al mercado global. Se parte del supuesto de que la filosofía ha superado el oficio de "acomodadora", fijadora de linderos, e inspectora de los roles que dentro de la cultura deben desempeñar lo "cognitivoinstrumental, lo práctico-moral y lo estético expresivo", y que se constituye en mediadora del debate entre estas.

La crisis de la universidad se ubica en el horizonte más amplio de la crisis de la modernidad, como fruto de la fracturación de la racionalidad emancipatoria y del posicionamiento de la razón económica en detrimento del sujeto ético-político.

Metodología. Sin desconocer los aportes de la "universidad nacida en el medioevo", sobre todo en lo concerniente con el abordaje holístico y corporativo de algunos asuntos novedosos en su momento, como el legado aristotélico, el análisis que en este artículo se efectúa toma como referente el sistema universitario heredado de la modernidad ilustrada, asimilado por el ethos cultural colombiano y oficialmente vigente en la actualidad. En el contexto latinoamericano se recurre, entre otros aportes, a los estudios efectuados en los últimos diez años por entidades como la Unesco, la CEPAL e instituciones independientes dedicadas a la cualificación de la educación superior en América Latina. En el caso colombiano se aborda el estudio desde los derechos fundamentales trazados por la Constitución de 1991 y la Ley 30 de 1992. Se tienen en cuenta tanto lineamientos estatales como estudios no oficiales que se ocupan de la crisis del sistema universitario, sobre todo en relación con el desarrollo humano de las personas.

Resultados y conclusión. Se propone el enfoque de desarrollo humano como horizonte posible de formación de capacidades y competencias, enriqueciéndolo a la luz de los aportes de Martha Nussbaum. En torno a las alternativas de fortalecimiento del enfoque personalizado, se articulan la propuesta pedagógica responsiva de J.J Sedano, con el enfoque comprensivo de Bernard Lonergan, ambos enfáticos en la centralidad del sujeto que se forma en una realidad concreta y para dar respuesta consciente a las necesidades de la realidad histórica.

* El servicio público de educación de tercer nivel se considera inherente a la finalidad social del Estado colombiano (CPC, arts. 67 y 189 numerales 21 , 22, 26, Ley 30 de 1992). Véase Orozco (2014, pp. 31-77). Pues, a pesar del incremento en la cobertura y en el crédito educativo para los sectores de menores ingresos, se perpetúa y consolida el control de parte del Gobierno en lugar de incrementarse la inversión en calidad, y en estrategias de trasparencia y optimización de la oferta educativa. En (Gaviria y otros, 2014, pp. 70-119) los autores constatan la tendencia de un alto porcentaje de universidades privadas que depende cada vez más de los recursos de los padres de los estudiantes, casi siempre de estratos bajos, y por coincidencia con bajos resultados en las pruebas Saber 11, ya que quienes obtienen mejores resultados de estos estratos optan por la educación pública; además, la relación entre mejores resultados Saber 11 y mejores pruebas Saber PRO, coinciden con instituciones certificadas de alta calidad, casi siempre universidades públicas o privadas con tendencia elitista. 
Desde la perspectiva hermenéutica y pragmática se invita a indagar por los nuevos fundamentos de la propuesta educativa de tercer nivel, a fin de que sea pertinente para las necesidades de las personas de hoy.

Palabras clave: Universidad en crisis, desarrollo humano, capacidades, competencias, pedagogía, responsabilidad y comprensión.

\section{Abstract}

This reflection article outlines the concerns and interpretations that emerge in the daily communicative praxis about the crisis of the university, its effects on society, and possible alternative solutions not only from science, technology or global market, but also from the wide horizon of the humanities. It is assumed that philosophy has exceeded the office of "settler", fixing boundaries and checking the roles that the "cognitive-instrumental, practical-moral and aesthetic expressive" should play, mediating the debate between them. The crisis of the university is located in the wider horizon of the crisis of modernity, as a result of the fracturing of the emancipatory rationality and positioning of the economic reason against the ethical-political subject.

Methodology: In this article, the author analyzes the Higher Education System inherited from the Enlightenment Modernity and assimilated by the current cultural Colombian ethos, inasmuch as what medieval universities gave to current higher education institutions is recognized, specially concerning the holistic and corporate approach of novelties in their times, such as the Aristotelian legacy. From the Latin American context, among other references, the author takes into account the reports from institutions such as UNESCO, ECLAC and independent institutions devoted to the study of the qualification of higher education in Latin America. In the Colombian case, the author reflects on the study of the fundamental human rights traced by the Constitution of 1991 and the Act 30 from 1992.

Results and conclusión: The author proposes the human development focus as the possible horizon for the Education based on skills and competences, enriched by the findings of Martha Nussbaum. Reflecting on the choices for strengthening the personalized approach, the author articulates the responsive pedagogy proposed by J.J. Sedano and the comprehension approach by Bernard Lonergan, both of which are emphatic in the centrality of the subject formed in a concrete reality and in order to respond consciously to the needs of a historical context. From a hermeneutical and pragmatic perspective, the author invites to inquire on the new foundations of the higher education proposal, aiming at its pertinence to the needs of people nowadays.
Keywords: University in crisis, human development, abilities, skills, pedagogy, responsibility and understanding.

\section{Introducción}

Al parecer la crisis de la universidad occidental es de "vacío de sujeto político o de nueva ciudadanía", y para entenderla mejor conviene analizarla de cara a la crisis de la modernidad'. Así procede Boaventura de Sousa Santos (2012)², quien evidencia en dicha crisis contradicciones y tensiones entre la alta cultura científica y académica, fruto de la investigación más refinada, y la baja cultura orientada a cubrir las exigencias de entrenamiento de las masas. Además, subraya que, tanto la "crisis de hegemonía" 3 de

1 A manera de tesis sostiene el analista que la crisis de la modernidad obedece al exceso en el cumplimiento de algunas de sus promesas socio-culturales, y al déficit en el cumplimiento de otras, relacionadas con los dos pilares en que se sostiene, a saber: el de la regulación, que se apoya en los principios de Estado, de mercado y de comunidad; $y$ en el pilar de la emancipación, alimentado por la racionalidad estético-expresiva, moral-práctica, y cognitivoinstrumental. Dichas lógicas o principios están entrelazadas, de modo tal que la identidad y la comunidad se relacionan con lo estético-expresivo; el derecho y la ética con la acción reguladora del Estado, y lo cognitivo-instrumental con el principio de mercado, en cuanto que de este vínculo se alimenta la producción y la competitividad. La contradicción se genera por la pretensión maximalista de lo regulatorio y lo emancipatorio que mirados desde lo concreto y práctico resultan contradictorios y generadores de tensiones entre "la justicia y la autonomía; la solidaridad y la identidad; la emancipación y la subjetividad, y la igualdad y la libertad" (De Sousa Santos, 2012, pp. 85-91). También Terrén (1999, pp. 173-175) contextualiza el análisis de la crisis de la universidad dentro de la crisis de la modernidad, en tanto que esta devino en "modernización" del brazo de la industrialización, la tecnología y la sociedad de bienestar. Para Umberto Eco (2012, pp. 159-167) las crisis de la racionalidad son varias y no necesariamente negativas.

2 Para corroborarlo se remite a los objetivos propuestos por Karl Jaspers $(1965$, pp. 19, 51) acerca de la búsqueda asidua y sistemática de la verdad por medio de la investigación, la problematización contextual, el debate informado, y la construcción cultural de lo humano como un todo integral. Objetivos que con el paso de los años devienen en lo utilitario, funcionalista y administrativista, según lo requiera la economía de mercado, claramente contradictorios con la naturaleza democrática y los objetivos de dignificación humana y equidad social promulgados por la modernidad (De Sousa Santos, 2012, pp. 225-230).

3 Crisis a manera de tensiones dicotómicas entre la alta cultura especulativa, tradicional y privilegiada, y la cultura inculta de las masas; entre la educación y el trabajo. Así dentro de los programas de formación de la dirigencia se incluyó la formación para el trabajo, el desempeño técnico y la producción. Como resultado la educación se parceló en cultura general, profesional y para el trabajo. La universidad reaccionó impulsando la especialización. La crisis de hegemonía se manifiesta, también como tensión entre la teoría y la práctica; la universidad, la productividad y la comunidad (De Sousa Santos, 2012, pp. 232-255). 
la universidad, como su "crisis de legitimidad"4, obedecen a la preponderancia que adquiere la lucha por los derechos humanos, económicos, políticos, educativos y sociales, motivada por el imperativo de hacer congruentes los principios de igualdad, libertad y solidaridad universitarios con los principios de democracia y equidad social.

De la suma y recrudecimiento de las crisis anteriores, fruto del impacto de la economía global, emerge la "crisis institucional" ligada a la búsqueda de sostenibilidad económica y a la gestión eficiente del potencial humano. El peso de la burocracia desplaza los planteamientos morales, para dar prioridad al funcionamiento óptimo y al rendimiento mercantilista. En consecuencia, la cultura y el conocimiento devienen en "inversión financiera" (Terrén, 1999, pp. 174-179).

El desplazamiento ejercido por la racionalidad hegemónica de lo cognoscitivo-instrumental, quiebra la integración, el diálogo, y la intercomunicación diferenciada con la racionalidad moral-práctica y la racionalidad estéticoexpresiva.

En consecuencia, la crisis del paradigma científico-tecnológico moderno arrastra tras de sí al tipo de universidad engendrado en la modernidad, conduciéndola al ocultamiento del sujeto político, a la relativización de las implicaciones de las intersubjetividades, y a la postergación del debate ético sobre la viabilidad de la vida humana y la sostenibilidad ecológica. Por consiguiente, disimular, encubrir o soslayar no es la opción ético-científica viable para hacer frente a dicha crisis; sobre todo si se tiene en cuenta que la naturaleza de la universidad moderna es el debate, pues llamada a "pensarse a

4 Relacionada con la coherencia entre los principios de la universidad y los de la democracia social de derecho, en el caso de Colombia. Por su carácter elitista, la legitimidad de la universidad ha estado siempre en entredicho (De Sousa Santos, 2012, pp. 255259). Pero, es la crisis impuesta por la productividad, el mercado, la eficiencia, el afán de lucro y el economicismo la que con mayor fuerza impacta la naturaleza y misión de la universidad (De Sousa Santos, 2012, pp. 259-270). sí misma de manera crítica, reflexiva y contextual", la universidad enfrenta los interrogantes que le plantean la racionalidad moral-práctica y la racionalidad estético-expresiva, desplazadas por la intromisión mercantilista, sobre todo, a través de la cooptación de lo cognoscitivo-instrumental ${ }^{5}$. De hecho, la pretensión civilizatoria de la modernidad empeñada en "lo mejor, lo deseable, universal y perfecto" devino en unidimensional, híper-racionalista y homogeneizadora y, sobre todo en funcionalismo tecnócrata de espaldas a la cotidianidad ${ }^{6}$.

A la universidad moderna, además de los desafíos anteriores, le corresponde ahora afrontar los planteados por las culturas ancestrales de pueblos y naciones con otras epistemologías, modos de vida, cosmovisiones, regulaciones éticas y políticas, que a juicio de la racionalidad moderna no gozan de estatus "científico" ni civilizatorio. El enfoque multicultural y pluri-étnico no encaja dentro de las pretensiones totalitarias y reduccionistas de la mayoría de los "programas" académicos de formación profesional. En consecuencia, el reto de construir un nuevo ethos universitario reivindica su misión original de apertura al "otro"?

5 Santos (2012, pp. 269-275) reinterpreta el nuevo papel de las racionalidades modernas desde la perspectiva de la posmodernidad. En el proyecto de "Acuerdo por lo superior 2034" el abordaje tecnócrata y administrativista es evidente, tal como lo denunció Edgar Morin en su momento. Sin embargo, a pesar de que "la ciencia nos ayuda a entender el mundo y la vida, a cualificar la salud y a proteger el medio ambiente", a comunicarnos, y a optimizar los procesos de mercado y seguridad ciudadana, la actual ley de ciencia y tecnología no lo juzga así (Wasserman, 2015).

6 El progreso material, el desarrollo económico y la competitividad tecnológica no son equiparables al desarrollo humano. Suplantada la ética, estropeada la crítica y la confrontación no hay cabida para la diferencia. Queda franqueado el paso para la unidimensionalidad y el integrismo; la estética y demás expresiones culturales pasan a ser decorativas. Como reacción ante semejante estado de cosas, la universidad debe empeñarse en recuperar el bildung, el desarrollo humano integral, en renovarse pedagógicamente, y en recuperar la comunidad cultural integrándola en sus proyectos (Terrén, 1999, pp. 184-195).

7 De Sousa Santos (2012, pp. 275-281) traza la ruta de acciones y procesos con base en las tesis planteadas por él para avanzar hacia un modelo de "universidad que aprende" gestionando las crisis que la afectan. A las críticas actuales sobre la pérdida de horizonte político-humanista de la universidad, se suman Bauman y Donskis (2015, pp. 61-67), quienes conceptúan que al parecer los hechos cotidianos de exclusión no son asuntos de análisis y compromiso para la academia, poco sensible, apática y preocupada por el progreso, pues el afán de futuro no da cabida a la reflexión y al pen- 
Para Ulrich Beck y Anthony Giddens (2001) ${ }^{8}$ la crisis de las instituciones modernas, incluido el tipo de universidad nacido de esta, yacen incubadas desde sus propios cimientos por el socavamiento de los presupuestos de la sociedad industrial, por los cambios sociales provocados por la sociedad misma en ausencia de liderazgo de lo político que devinieron en soluciones nacionalistas y fundamentalistas. El Ilamado hecho por la sociedad del riesgo para que la universidad moderna se transforme y contribuya a la transformación de la cultura pasa por el debate crítico de sus fragilidades acumuladas, múltiples e inocultables, sin que se les califique como residuos del progreso o se les legitime como situaciones incontrolables.

La universidad moderna al "pensarse de manera crítica" contribuye a la transformación de las cosmovisiones socio-culturales, se constituye en objeto de auto-reflexión pública, política y científica; se innova, gana credibilidad, legitimidad y capacidad de respuesta para enfrentar la dilapidación impuesta por la sociedad del riesgo globalizado, contra los bienes comunes naturales, sociales, políticos, científicos y culturales ${ }^{9}$. De ella se espera también que desmonopolice la construcción del conocimiento del formato impuesto por el eurocentrismo científico, y promueva otras alternativas epistémicas complejas, multidisciplinares, transdisciplinares y éticas ${ }^{10}$.

samiento crítico. De ahí que las universidades, transformadas en "organismos semi-corporativos" mercadeables y de alta eficiencia, se olvidaron de investigar para transformar la realidad social. Con la pérdida de lo político se degrada hasta desaparecer la que fuera propulsora de los principios de la modernidad crítica: los estudios clásicos ya no existen y la muerte del humanismo ronda en la Universidad de Humboldt. Citando a George Steiner, consideran que en las universidades no hay espacio para atender con rigurosidad al pensamiento crítico, pues el afán de la vida colapsó el lenguaje, se devino en distopías y comercio "de ideas" a gusto del consumidor.

8 Pero, ¿cómo puede decodificarse la modernización reflexiva de cara al papel de la universidad en la reproducción de la modernidad normal o convencional? (Beck, Giddens y Lash, 2001).

9 La explosión de las desigualdades ha desplazado al sujeto del centro de las preocupaciones de la sociedad actual. El retorno de la incertidumbre y el riesgo hace que los problemas dejen de ser tratados como resultado de la falta de regulación, equívoco en el cálculo probabilístico, orden y gestión, para ser tratados como problemas relacionados con la supervivencia humana (Beck, Giddens, y Lash, 2001, pp. 13-73).

10 La universidad convencional se apropia de la tradición para con-
En síntesis, el horizonte delineado con anterioridad aporta nuevos criterios para el análisis de la complejidad, y el emprendimiento de la tarea de resignificación de la misión de la Universidad Santo Tomás en Colombia, si se tiene en cuenta que su mayor desafío es contribuir a la transformación del ethos cultural colombiano, de cara a las exigencias del posconflicto y la convivencia pacífica. Así pues, antes de ahondar en el alcance y pertinencia de la propuesta de desarrollo humano por capacidades y competencias, como alternativa de respuesta viable a la crisis actual del sistema universitario, nos detendremos a indagar en algunos de los estudios recientes que se han ocupado del mismo asunto; trataremos de identificar en estos los enfoques y aportes más significativos; sobre todo, en lo relacionado con el desarrollo humano integral, liberador, equitativo, democrático y científicamente fundamentado.

\section{Metodología}

\section{El Contexto}

Las fuentes que a continuación se analizan coinciden en torno al propósito de buscar la calidad de la oferta educativa de tercer nivel. Algunas de ellas subrayan el papel que cumple este tipo de educación en la consolidación de las instituciones democráticas, en el desarrollo del país y en el aprovechamiento de los beneficios científicos, tecnológicos y económicos. Salvo contadas excepciones sus enfoques se circunscriben dentro de las demandas y exigencias del capitalismo globalizado, y ninguno trae a colación experiencias exitosas de formación de tercer nivel centradas en el desarrollo de las personas que soporten sus análisis; es de entender que esto ocurre dada la naturaleza y los

vertirla en "ritual" de reconocimiento, prestigio social y reproducción de jerarquías: elimina lo "impredecible" del presente para identificarse con el pasado y controlar el futuro. Se prolonga en el tiempo por medio de la repetición ritual y de los formalismos, que le den continuidad, la legitimen, la identifiquen y la hagan vinculante, en lugar de reconocerse en la "autenticidad" del presente que la desafía (Beck, Giddens, y Lash, 2001, pp. 75-136). Cabe anotar que, de acuerdo con los fines del presente artículo se adopta el significado de capacidad como "ser más", tal y cual se recoge en la propuesta de Martha Nussbaum (2012). 
fines de cada uno de los estudios citados; aun así, sus aportes son valiosos, dejan entrever los contextos y perspectivas de análisis, e invitan a complementarlos con la propuesta desarrollo humano por capacidades y competencias.

Los miembros de la llamada "comisión de sabios" que en 1993 presentó el informe Colombia al filo de la oportunidad, conocedores de la brecha creciente entre países desarrollados y subdesarrollados, con la mirada puesta en el futuro se planteaban la necesidad de "redefinir el desarrollo humano", pero atendiendo a la pregunta: ¿cómo modernizar la educación, acelerar el avance científico y tecnológico, consolidar la capacidad de crecimiento económico, e impulsar sosteniblemente la ciencia, la educación y el desarrollo, de forma tal que se aseguren el bienestar y el progreso democráticos de todos los colombianos? Aún más, enfatizaron en la necesidad de transformar el ethos socio-cultural colombiano, con el propósito de incrementar el "potencial creativo y civilizador" de sus gentes, de cara a la competencia intelectual e innovadora de otras naciones (Misión de Educación, Ciencia y Desarrollo, 1996, pp. 30-33).

Al constatar en su momento la agudización de las crisis socio-ambiental, económica y política de los países más desarrollados, la comisión insiste en que en el caso de Colombia, dicho desarrollo requiere de un "contexto civilizador" que se fundamente en el respeto por la vida y propenda por el bienestar social de todos. En consecuencia, subraya que "el desarrollo debe entenderse como trasformación del "ethos cultural", avance humano, económico, político y cultural" que "potencie al máximo" las capacidades intelectuales y organizativas, la innovación en el entender y en el hacer, y el desarrollo del talento científico, artístico y literario. En definitiva, un proyecto "civilizador" que fomente la libertad, la igualdad y la prosperidad ${ }^{11}$, educan-

11 El informe de los comisionados está marcado por el afán aperturista de las políticas económicas $y$, sobre todo, por las expectativas de convivencia y diálogo que trae la Constitución de 1991. do el activo más "valioso de Colombia que es su gente", para que ingrese y aporte al "nuevo orden científico y tecnológico"12.

Los comisionados, preocupados con los desafíos de la apertura económica, reconocen, en ese momento, que se carece del potencial humano para afrontar los retos de la sociedad y la economía del conocimiento, pero sobre todo que "es indispensable un nuevo sistema educativo"13, pensado, organizado y proyectado a largo plazo para la construcción de civilidad y convivencia por medio de una"formación integral" óptima que: "promueva la dignidad humana, la autoestima, el respeto por la vida, la creatividad, el racionalismo científico y la apertura a nuevas concepciones de mundo" ${ }^{\prime 14}$.

De acuerdo con su análisis, aprovechar la ciencia y la tecnología por medio de la educación para potenciar y acelerar el desarrollo ${ }^{15}$ produce mayor impacto y pertinencia cuando se hace desde las regiones, con el aprovechamiento óptimo de los recursos ambientales y las bases culturales locales, siempre con el propósito de suplir la carencia de los científicos que requiere el país ${ }^{16}$.

12 Por la formación de capacidades informacionales, científicas, tecnológicas y artísticas (Misión de Educación, Ciencia y Desarrollo, 1993, p. 34).

13 Se habla de capital humano y la formación del mismo se plantea en "habilidades" no como se entiende ahora según la perspectiva de "desarrollo humano": capacidades.

14 Como se verá más adelante en Crear capacidades, de Nussbaum (2011), la propuesta de la comisión guarda analogía con el desarrollo humano. El patrimonio más importante de los colombianos son sus vidas y sus mentes: "la posibilidad de ser creadores de su propia historia" y su patrimonio cultural (Misión de Educación, Ciencia y Desarrollo, 1993, pp. 35-36). Tal propósito no se cumple con el sistema educativo actual.

15 El desarrollo se concibe en este apartado del informe en términos de crecimiento económico, aunque se hace la relación con capital humano y mejoramiento de las condiciones laborales, es decir, como inversión costo-efectiva-productiva. Pero, no solo así, también como calidad de vida favorecida por los avances científicos; por el aprovechamiento del capital científico que propicie la democratización del conocimiento y facilite a la mayoría el disfrute del patrimonio universal del saber, pero sobre todo que construya la masa crítica de analizadores de información y científicos líderes en innovación y creatividad. El cambio en las organizaciones debe ir a la par que la co-evolución que se da entre ciencia-tecnologíaeducación y restructuración de los bloques económicos (Misión de Educación, Ciencia y Desarrollo, 1993, pp. 39-41).

16 Se considera que el científico es un profesional, doctor, con entrenamiento y experiencia en investigación; reconocido por la calidad y cantidad de sus investigaciones, miembro de centros de 
Conceptúan los comisionados que el debate actual sobre los factores que intervienen en el desarrollo humano recoge el debate antiguo relacionado con el papel de los sujetos responsables; los condicionamientos de los contextos culturales, sociales, políticos y éticos; la disponibilidad de recursos; el papel de las instituciones; el acceso de los interesados al conocimiento $y$, sobre todo, el influjo de las fuerzas de mercado; polémica que se agudiza aún más por el impacto que los avances en ciencia, tecnología y globalización tienen en las economías y en la calidad del empleo en los países en vía de desarrollo ${ }^{17}$.

Como se anotó con anterioridad, dicha transformación es agenciada, sobre todo por las instituciones, pues son estas las que frenan o posibilitan la autorrealización de los sujetos, impiden los cambios, consolidan marcos de valores, perpetúan modos de poder. De aquí que a estas les sea perentorio aprender a adaptarse a los nuevos requerimientos ${ }^{18}$. En el caso de las instituciones de educación superior por respeto a las personas que las conforman y porque deben generar confianza formativa, vigencia científica y significatividad social, precisan potenciar al máximo las capacidades de

investigación y publicaciones altamente referenciadas (Misión de Educación, Ciencia y Desarrollo, 1993, p. 37).

17 La promulgación de una nueva carta política como respuesta a la pérdida de legitimidad del Estado, al influjo de la corrupción y el narcotráfico, el proceso de modernización del Estado y la economía hacen de este momento el propicio para enfatizar en la necesidad de transformar el sistema educativo y promover el cambio civilizatorio, pues: "el desarrollo de las personas está basado en el aprendizaje, entendido como el proceso amplio y continuo por el cual se adquieren conocimientos y habilidades para sobrevivir, para responder creativamente a los cambios en el medio y así evolucionar y progresar" (Misión de Educación, Ciencia y Desarrollo, 1993, pp. 41, 56). Pero es desempeño social e institucional el que evidencia el nivel de integración del individuo al proyecto colectivo.

18 Según el documento de los sabios: "el aprendizaje se define como el proceso por el cual un individuo adquiere la capacidad de responder a los cambios que se producen en su ambiente". A reglón seguido establecen que: "el aprendizaje de los seres humanos se diferencia del aprendizaje de los demás seres vivos, en que no solo responde de manera adaptativa e instrumental, sino que lo hace en forma creativa, trasformadora, re-constructiva y comprometida con la sociedad". En la medida en la cual el aprendizaje trasforme a los sujetos, también provoca cambios en los colectivos y en las organizaciones (Misión de Educación, Ciencia y Desarrollo, 1993, pp. 56-58). sus miembros, sobre todo la comprensión imaginativa, el diálogo ético, el trabajo en equipo exploratorio y experimental, la reflexión crítica y el pensamiento sistémico ${ }^{19}$.

Con el propósito de articular y resignificar la educación superior en el marco de la Carta Política de 1991, la Ley 30 de 1992, documento que traza las bases políticas en materia de educación superior, adopta el paradigma de los derechos humanos y reafirma que "la finalidad de la educación de tercer nivel es propiciar el desarrollo integral de la persona y la adquisición de competencias básicas para ser, hacer, comprender, participar y convivir" 20 . Si bien es cierto que, dentro de los lineamientos expuestos por el Gobierno nacional en 2001 (Orozco, 2001)21, el documento, además de constatar cómo la interferencia e interdependencia económica y financiera, fruto de la globalización, menoscaba la identidad socio-cultural y política del pueblo colombiano, ahonda las desigualdades, pospone la satisfacción de las necesidades para la mayoría de las personas, ese documento no aborda el impacto de esas políticas en el "desarrollo humano"22. También reconoce el valor intrínseco

19 La necesidad de re-conceptualizar la gestión de las universidades es tarea pendiente en un alto porcentaje de estas instituciones, sobre todo en las muy tradicionalistas y jerarquizadas o en aquellas que no han integrado el conocimiento y la tecnología en el mejoramiento permanente y en el desarrollo del potencial humano. Los comisionados consideran que la educación "es el proceso por el cual los individuos se apropian del bagaje cultural y experiencial de sus antecesores, lo apropia y lo utiliza para la sobrevivencia, la construcción social y el vínculo comunitario". Por eso insisten en atender a los siguientes problemas de la educación: falta de calidad, predominio de la instrucción, descuido de los valores y principios y, del papel gestor de las instituciones; políticas estatales desinformadas, centralistas, discontinuas; en cuanto a los docentes (Misión de Educación, Ciencia y Desarrollo, 1993, pp. 58-65).

20 Textos que vinculan la "integralidad" de la formación superior con los derechos humanos y por consiguiente con las competencias que las concretan (C.P., art 365; Ley 30 de Educación Superior, art. 2, 1992), y, con las orientaciones del MEN-Icfes (2001, pp. 46-47) sobre los cambios que se deben efectuar en IES.

21 Texto que sintoniza con los aportes de Jacques Delors (1996).

22 El crecimiento financiero se concentra en unos pocos, el capital incuba más capital, pero no redistribuye en beneficio de la mayoría de la población. El incremento de la matrícula de tercer nivel se sostiene durante varios años, posiblemente debido a la proliferación de instituciones de poca calidad y reducido control estatal. A pesar de todo, la inequidad del sistema de educación superior se acentúa con los altos índices de deserción. En cuanto a la calidad de las prácticas docentes se mantienen en lo tradicional de hablar, copiar, memorizar y reproducir (Orozco, 2001, pp. 9-17). 


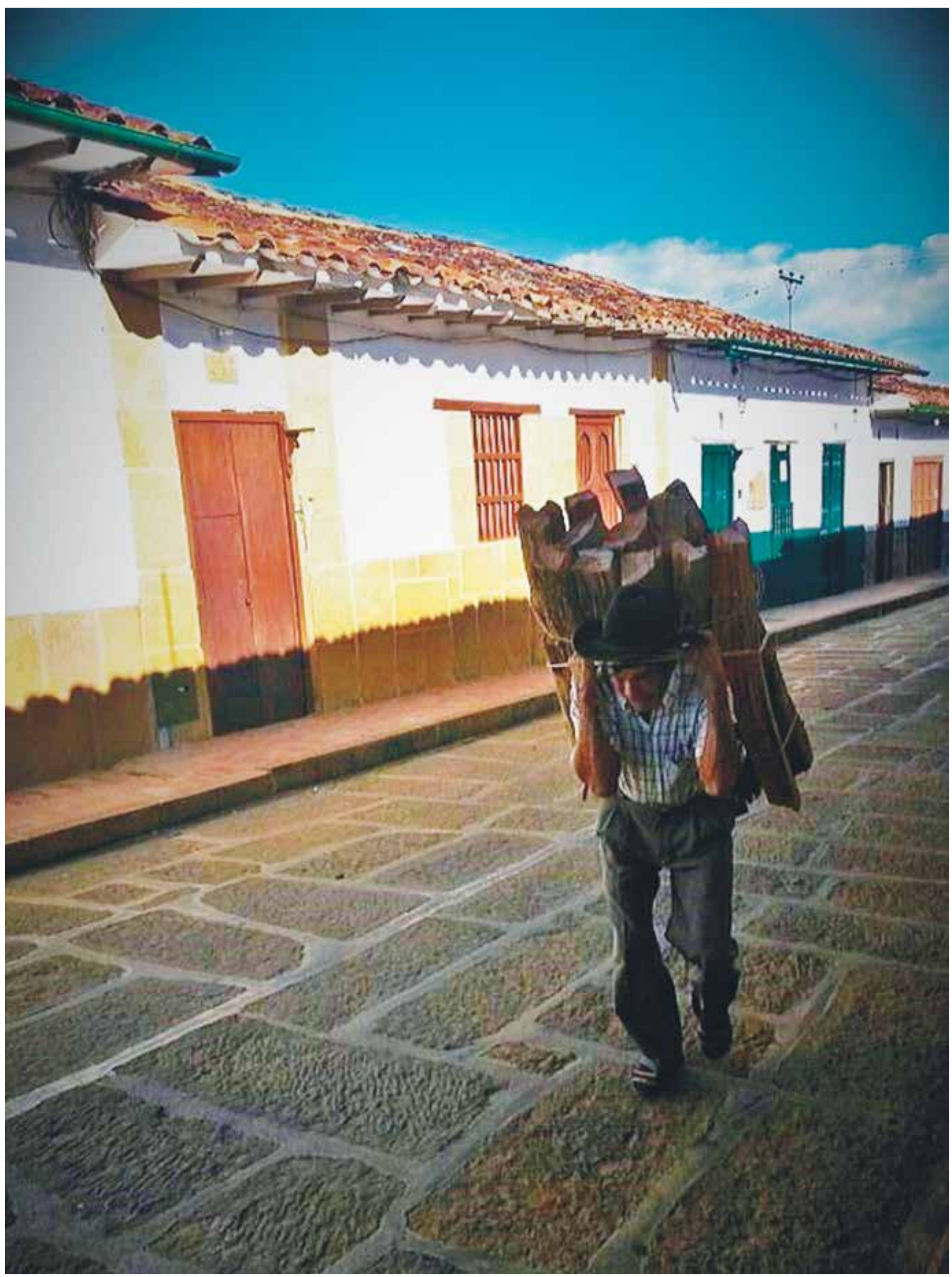


de la educación como asunto de dignidad ${ }^{23}$ personal y social, que encuentra en el horizonte de lo "público" la posibilidad de integrarse en la construcción del ethos común ${ }^{24}$, aporta al desarrollo del talento humano y al "proyecto de vida" individual ${ }^{25}$; a la democracia social de derecho y al fortalecimiento de las libertades humanas ${ }^{26}$, independientemente de la tasa de retorno". Los expertos que trazan la política identifican como ejes centrales para enfatizar: la cobertura con equidad, el financiamiento de la calidad y la autonomía con responsabilidad ${ }^{27}$; más adelante al referirse al contenido e implicaciones de la "formación integral" proponen las capacidades y competencias que consideran adecuadas para la oferta tecnológica, profesional y de posgrados ${ }^{28}$.

23 Sobre el eje: vida-dignidad-igualdad humanas, se articulan y despliegan "los derechos humanos", tal y como los concibe la Carta Política de 1991. Doctrina que, a su vez se fundamenta en los aporte de los filósofos estoicos y en la relectura de Aristóteles, quien afirmaba que: "el primer deber de quien gobierna es proteger a los ciudadanos y guiarlos por medio de la justicia al bienestar", efectuada por Santo Tomás de Aquino en relación con la "Ley natural", para quien "existe una dimensión moral de la realidad", por consiguiente la ética media la construcción justa y humanizante de los proyectos de vida de las personas, dado que, valores y derechos humanos son de carácter universal. Todo atentado contra el eje fundante de la ley natural, vida-dignidad-e-igualdad es violatorio de dicha ley que, debe complementarse con el enfoque ecológico.

24 Pues, según los analistas, desde el enfoque del Estado Social de Derecho el colectivo es el horizonte de las interrelaciones entre iguales, de la concreción de las libertades, de la práctica de los valores y de la realización del "proyecto de vida" (Orozco, 2001, cita 6, p. 19).

25 Que si bien hace énfasis en los aportes de Amartya Sen (ver cita 9), en cuanto al enfoque socio-político del desarrollo de capacidades $y$, aunque más adelante en el capítulo seis (6) al abordar la "formación integral" retoma para centrarlo en los individuos, se hace indispensable enriquecerlo con los nuevos aportes de Martha Nussbaum (2012).

26 Y no solo con las posibilidades de lucro, tan significativo desde la perspectiva rentista de la educación (Nussbaum, 2010).

27 Después del análisis de las cifras tomadas de los Informes para el Desarrollo Humano de las Naciones Unidas los expertos no concluyen de manera explícita que haya que potenciar las oportunidades de desarrollo humano de los individuos para cualificar las sociedades, menos aún que haya que poner atención en la calidad de los docentes para cualificar la oferta educativa de tercer nivel (p. 18).

28 Subraya la política la "importancia de que sean coherentes dentro del PEI: la estrategia educativa, la misión, fines, objetivos y acciones que le dan identidad... las competencias que las personas pueden aprender dentro de un programa de formación profesional. Considera que las competencias son: Conjunto de conocimientos, enfoques, metodologías y actitudes, valores y creencias adquiridas que posibilitan las acciones pertinentes en contexto de trabajo" (p. 58). Más adelante, diferencia entre capacidades y
Por su parte, el texto Bases para la política de educación superior (2001), que recoge los aportes de Carlos Augusto Hernández (Orozco, p. 19, cita 7), (Hernández, 2000, pp. 225 y ss.) sobre las relaciones entre ciencia, universidad e investigación, acentúa el carácter público de las universidades y, por consiguiente, la misión que asumen de "formar individuos idóneos y competentes" desde la perspectiva del saber, "con capacidad para hacer uso público de la razón", "ampliar el saber necesario para el desarrollo colectivo", y crear y generar bienes culturales. Se invita a las universidades a asumir lo "público" en su misión y visión, dado el impacto que la educación superior tiene en el potencial de desarrollo local, regional y nacional ${ }^{29}$. En consecuencia, medir la significación de la educación superior por indicadores como la "tasa de retorno" o el mejoramiento de los salarios, no se conduele con el valor intrínseco que esta aporta a la consolidación y cultivo del talento humano, al despliegue de las potencialidades internas de las personas, al bienestar social y al desarrollo del conocimiento intercultural ${ }^{30}$.

El enfoque tradicional de lo universitario, reflexivo especulativo, de tendencia teleológica, difiere del modelo pragmático ${ }^{31}$ que enfatiza en las respuestas concretas y prioritarias a las necesidades de bienestar individual, de satis-

competencias, poniendo las primeras en función de las segundas (p. 61).

29 Desde la perspectiva de lo público la propuesta de políticas replantea el papel de la universidad en la medida que ella mejora el proyecto de vida de las personas, incrementa la productividad del país y le permite insertarse en la dinámica de la globalización (Orozco, pp. 20-22).

30 Aunque, el desarrollo del conocimiento propicia el desarrollo económico, al parecer profundiza la brecha de inequidad social, sobre todo cuando esta no es de alta calidad (Orozco, pp. 21-24).

31 Sin que sea fruto de un análisis profundo y sustentado se establecen diferencias entre el modelo reflexivo y el modelo pragmático de universidad. El modelo reflexivo asume el enfoque del observador externo o analista "neutral" que posicionado en las disciplinas y en la ciencia misma fija las reglas de abordaje de la realidad y, busca el conocimiento por sí mismo. En cambio, la mirada pragmática apunta al "contexto de aplicación", investiga en función de la utilidad, flexibiliza los métodos y las técnicas adaptándolas al objeto, a los propósitos de la investigación y a los equipos responsables. El peso del modelo reflexivo en las universidades se perpetúa a través de elites de poder que reclaman sumisión a la autoridad, fidelidad a la tradición y salvaguarda de los valores "esenciales", para estos lo histórico y contextual pesa poco (Orozco, pp. 45-46). 
facción económico-financiera, y de despliegue de las libertades dentro de un contexto sociohistórico específico. La concepción tradicional de la universidad busca el conocimiento por el valor que éste tiene en sí mismo. En cambio el otro enfoque se ocupa de que el conocimiento sea pertinente, que posibilite el desempeño práctico de capacidades que propicien la interrelación y el cambio; caso concreto de la adquisición de capacidades informacionales, que miran a la construcción de conocimientos interactivos $^{32}$.

Los lineamientos de la política también postulan la educación a lo largo de la vida como uno de los ejes dinamizadores de la oferta formativa y de las estrategias de respuesta a la demanda de pertinencia social ${ }^{33}$, pues el desarrollo de nuevas capacidades y el fortalecimiento de las ya adquiridas es tarea permanente, dado el cambio de contextos, la demanda de competencias transdisciplinares, y la incertidumbre, precariedad y caducidad del conocimiento. El surgimiento de zonas traslapadas de profesiones y disciplinas, y la exigencia de dominar varios campos de acción y desempeño laboral, reivindica el desarrollo de capacidades y competencias complejas adecuadas a las necesidades trans-disciplinares ${ }^{34}$.

La insistencia en que la oferta de educación superior se estructure con base en las necesidades de las regiones de hecho obedece a la exigencia de pertinencia social, docencia cualificada e investigación de alto nivel, que ten-

32 Son los desempeños prácticos los que evidencian la pertinencia de los modelos formativos de la educación superior, no las ideas ni las teorías, afirman los defensores del modelo pragmático de universidad. Las nuevas demandas de trabajo, los avances del conocimiento, las nuevas tecnologías y la transformación de las profesiones hace emerger nuevas capacidades y nuevas competencias. Por ejemplo, las TIC requieren capacidades cognitivas para el análisis de símbolos, la construcción de significados, la adquisición de información, la valoración de la información, vigilancia e ingeniería de datos (Orozco, pp. 25-31).

33 En cuanto a formación del sujeto se apoya en los principios perfectibilidad y educabilidad y, en relación con el conocimiento, se fundamenta en la enseñabilidad de los saberes.

34 Constataciones que inexorablemente modifican la gestión y estructuración de los currículos de los programas académicos (Orozco, pp. 32-36). ga en cuenta el potencial de las localidades y forme los profesionales para la solución de problemas sociales, culturales y económicos concretos $^{35}$. A provechar las posibilidades y afrontar los desafíos de la globalización fortaleciendo el potencial de aprendizaje de la región significa que se acuerdan políticas, estrategias y planes de optimización de los recursos y apoyo mutuo entre las instituciones de educación superior, las empresas y el Estado ${ }^{36}$, según pautas comunes de "economía de aprendizaje".

Aun cuando haya diversos enfoques de desarrollo humano y de concepciones de la formación integral, queda en claro que el quehacer universitario es incentivar en las personas la capacidad de hacerse cargo de sí mismas, y por consiguiente debe adoptar las mediaciones que se requieran para que estas incorporen en su bagaje humano los conocimientos, las experiencias, los lenguajes, las culturas y los mundos de sentido que las hagan más capaces de ser, hacer, conocer, convivir, crear y transformarse permanentemente ${ }^{37}$. Proceso consciente que las libera de la auto-referencialidad egolátrica y las proyecta al encuentro solidario 38 por medio del lenguaje y la apropiación de otros mundos de vida.

35 Entendida la región como realidad histórico, cultural y geográfica que genera redes de reconocimiento y apropiación del mundo de sentido construido por generaciones $y$, diferenciado de otros ethos regionales (Orozco, pp. 64-65).

36 El documento sobre las "Bases para una política en educación superior" (2001) recoge, en la cita 42 (p. 67), el enfoque de "economía de aprendizaje" en el cual la capacidad de aprender de individuos e instituciones lidera los cambios necesarios, agencia las transformaciones y la creación de las competencias requeridas en relación con el aprovechamiento de la información, la endogenización y creación tecnológica.

37 El doctor Luis Enrique Orozco condensa en pocos párrafos el significado de la categoría "formación" desde la época clásica hasta el momento en que Hans-Georg Gadamer (1992) expone en Verdad y Método, I vol., p. 39, el artículo relacionado con la "formación", según la evolución de las ideas humanísticas en Occidente. (2001, cita 44, p. 82). Se aclara el sentido "poiético" de la formación y la razón por la cual esta no debe ser considerada como un "objetivo" externo a quien se forma.

38 Para algunos dicha incorporación y salida de sí, se comprende como un proceso de "ascenso en lo humano" desde el nivel de lo inmediato e instintivo, hasta el despliegue de la conciencia general e incluyente. El experto citado con anterioridad, encuentra en H. G. Gadamer (1992, pp. 41-51) una fuente aclaradora de las dimensiones y capacidades que requieren ser formadas siempre. 
Educar la sensibilidad conlleva capacitar para la percepción, el tacto atinado, la mesura y el cuidado del espacio íntimo de las personas, sobre todo si se tiene en cuenta que el respeto excluye la adulación, el culto a la personalidad y la manipulación. Además de la sensibilidad en el trato con los otros, también esta debe reflejar el cuidado consigo mismo, por la condición de precariedad y temporalidad de los sujetos. La dimensión sensible se enriquece por el obrar ético, flexible, justo, contextual y prudente, es decir, por el actuar responsable ${ }^{39}$.

Pero la educación pierde valor de integralidad si no se fortalece la capacidad comunicacional que posibilita religar vida personal, medio socio-cultural, tradición, ética, conocimiento y proyecto común. Frente a la caducidad de los macro-relatos argumentativos y prescriptivos tradicionales, toma ventaja la narración auto-biográfica: es decir, el compromiso con la resignificación del sentido de vida personal ${ }^{40}$.

En síntesis, la formación integral se propone el desarrollo de "competencias relacionadas con el pensamiento crítico; el discernimiento moral, el convivir, el comprender ético, estético y comunicacional" 41 .

Contribuye a iluminar el debate sobre la correlación posible entre el desarrollo humano, la equidad, la construcción de civilidad y la

39 A juicio de Luis Enrique Orozco (2001), la formación integral además de la "sensibilidad en general" frente a sí mismo, los otros y la historia, es también estética.

40 En síntesis, se considera que: "La formación integral es aquella que contribuye a enriquecer el proceso de socialización del estudiante, que afina su sensibilidad mediante el desarrollo de sus facultades intelectuales, artísticas, que contribuye a su desarrollo moral y que abre su espíritu al pensamiento crítico y al cultivo de una forma de vida en sociedad movilizada por valores de justicia y solidaridad, sin los cuales no es viable la vida en sociedad". Es integral en la medida en que ve al ser humano como totalidad, como fin que compromete e involucra a toda la universidad (Orozco, pp. 86-88).

41 Más adelante el texto sobre Bases para una política de estado en materia de educación superior (2001, pp. 89-92) incluye algunos aportes de Edgar Morin, acerca de Los siete saberes necesarios para la educación del Futuro (1999). Lo que subraya el carácter complejo del enfoque de formación integral. Ya la atención que en los lineamientos para la política de Estado sobre educación superior indistintamente se refieran a capacidades y competencias, sin hacer mayor precisión. educación superior, el estudio publicado por la CEPAL (2010) denominado La hora de la igualdad: brechas por cerrar, caminos por abrir, en el cual se subrayan de nuevo las falencias de la democracia en Latinoamérica, a saber: altos índices de exclusión, negación de oportunidades y violación de los derechos humanos. El informe reconoce que la "ciudadanía", como principio y derecho irreductible de cada individuo, se traduce en igualdad de derechos en educación, salud, empleo, vivienda, servicios básicos, calidad ambiental y seguridad social ${ }^{42}$. Además, constata que la expansión de la crisis del modelo industrial, de la globalización neoliberal, del individualismo y del mercado financiero obra a manera de pandemia sistémica agrava la desigualdad social. Como respuesta la CEPAL afirma que esta debe ser contrarrestada con "aumento de competitividad apoyado en el conocimiento y la innovación, en el uso sostenible de los recursos naturales y el cuidado del medio ambiente" ${ }^{\prime 3}$.

42 La agenda de la igualdad (CEPAL, 2010) promueve la inclusión, la interacción, la protección social y la solidaridad, sabiendo que: "hay que crecer para igualar y hay que igualar para crecer" potenciando las capacidades humanas, reduciendo las disparidades regionales, pues "la igualdad transforma a la dignidad y el bienestar de las personas en un valor irreductible, articula la vida democrática con la justicia social, vincula el acceso y las oportunidades con una ciudadanía efectiva... y vincula el marco normativo con la ratificación de los derechos". En la región latinoamericana y caribeña la igualdad se "ha visto sistemáticamente negada durante cinco siglos de discriminación racial, étnica y de género, con ciudadanos de primera y segunda categoría". El género, los cambios culturales, el acceso a las oportunidades, el respeto a las diferencias y los derechos humanos son componentes del debate educativo sobre el principio de igualdad. El análisis denuncia el descalabro del modelo financista que incrementó las desigualdades en los últimos años. La igualdad emerge de la dignidad humana, ambas se anidan dentro de la democracia y se concretan en derechos humanos. (Bárcenas, 2010, pp. 11-14). "La transición democrática y el equilibrio entre Estado-mercado-familia-educación, pide que se replantee la oferta educativa en términos de desarrollo de nuevas capacidades humanas genéricas y de servicios, a fin de que se prevea cómo responder a los retos del envejecimiento de la población mundial, carga que en alto porcentaje debe asumir el mundo sub-desarrollado; a la toma de conciencia de la diversidad cultural; a los conflictos interétnicos y religiosos; a la expansión del mercado de consumo; a la globalización de las comunicaciones y de la información; a la transformación de las identidades y los proyectos de vida; a los retos de la "tecno-sociabilidad" desreguladora y auto-reguladora global, y los riesgos de la crisis medio ambiental iniciada en la época industrial y agudizada con el desarrollo del capitalismo extractivo-destructivo de la vida (CEPAL, 2010, pp. 267-270).

43 La crisis de burbuja financiera ocasionada por la falta de regulación y supervisión del sistema y que contaminó "la contratación 
Al darle prioridad a la igualdad y a la libertad dentro de la agenda pública latinoamericana, la CEPAL reconoce los esfuerzos para consolidar la democracia, hacer vigentes los derechos políticos y civiles de los ciudadanos, superar la discriminación y resarcir los costos sociales de la crisis financiera. Empero, puntualiza que la lucha por la igualdad y la libertad demanda la abolición de privilegios, el ejercicio pleno de los derechos y obligaciones de los individuos, y el respeto a las instituciones y marcos normativos que garantizan el ejercicio de la ciudadanía ${ }^{44}$. Pero, "la igualdad política" pierde significatividad y contenido si al menos no se garantiza el umbral de satisfacción básico de las necesidades humanas ${ }^{45}$.

Recalca el documento que es sobre la dignidad humana que se funda la igualdad de los

del crédito, la destrucción de la riqueza financiera mundial, la disminución del comercio mundial y el deterioro de las expectativas sobre la evolución de la actividad económica. La crisis se expandió a través de los canales de crédito, de la reducción de las exportaciones y de las remesas que, se reflejan en la caída del PIB regional, en el aumento del desempleo y en la pérdida de los indicadores de desarrollo social. El análisis de la crisis centrado propone para enfrentar la recuperación de la actividad productiva, la reducción de la desigualdad social y "la recuperación de la senda del crecimiento, basándolo en el aumento de la competitividad apoyada en el conocimiento y la innovación. Los futuros escenarios de desarrollo los proyecta de acuerdo con las variables, estándares y medidas de regulación de la estructura, los sistemas y las políticas económicas delineadas, sobre todo por el Fondo Monetario Internacional, cuyas directrices en décadas pasadas condujeron al descalabro de varias de las economías de Latinoamérica. Al giro dado por el futuro a la nueva realidad económica y geopolítica del mundo se suman los desafíos ambientales de seguridad climática y atención a los niveles críticos de calentamiento global, pues: "pues la temperatura media del planeta está aumentando más allá de las tendencias normales y cuyas medidas de mitigación serán cada vez más costosas", dado que el cambio climático es acumulativo e irreversible (CEPAL, 2010, pp. 18-41).

44 Si bien la carta política vigente en el Estado social de derecho colombiano recoge el patrimonio de la carta sobre los derechos civiles del ciudadano y la declaración universal de los derechos humanos de las Naciones Unidas, estos principios necesitan concretarse en libertades, sobre todo por medio de la inversión en comunidades tradicionalmente vulneradas por la pobreza, la injusticia y el abandono del Estado (CEPAL, 2010, p. 42). El énfasis en el eje dignidad-igualdad-libertad, implica para la educación superior que, en el contexto de los diálogos de paz debe sumarse a quienes lideran los diálogos, a fin de que se incluyan en los proyectos educativos institucionales (CEPAL, 2010, pp. 255-261).

45 En consecuencia a la igualdad política que el sistema judicial debe proteger y garantizar, se suma la igualdad en justicia social, pues "afrontar los retos de la competitividad sin cohesión e inclusión social aumentará la conflictividad, pondrá en tela de juicio la legitimidad de los gobiernos y la sostenibilidad del crecimiento" (CEPAL, 2010, pp. 42-43, 240). derechos de los individuos y no solo sobre el "valor" que el mercado asigna a las personas, razón por la cual el informe de la CEPAL (2010) evita el empleo de la categoría "capital humano", y en su lugar hace énfasis en las "capacidades humanas" frutos del conocimiento, la innovación y la gestión educativa ${ }^{46}$. $E$ insiste en que la "competitividad auténtica" se basa en el desarrollo de mayores "capacidades humanas", garantizadas por la igualdad de oportunidades y el acceso a la educación de calidad. Por este camino, el desarrollo de las capacidades humanas posibilita la competitividad innovadora, económica y productiva, que repercute en mayor igualdad social ${ }^{47}$; pues en las tres últimas décadas la segmentación del mundo del trabajo y las alianzas-público privadas han incrementado las desigualdades en todos los ámbitos de la sociedad, sobre todo en protección social y educación ${ }^{48}$.

46 El informe aclara que: "Como ciudadanos y ciudadanas, los miembros de la sociedad no pueden subordinar su bienestar a su "capital humano", vale decir a la valorización de sus capacidades en una relación de oferta y demanda de trabajo, no solo por el acceso tan desigualdad a la educación y al conocimiento, sino porque ejercemos aquí una opción política por la ciudadanía como eje de inclusión". Es la ciudadanía la que da origen a la política de inclusión, y no la meritocracia, fruto del "capital humano" la que posibilita el goce de los beneficios del mercado (CEPAL, 2010, p. 43). Los vínculos entre la educación superior con los otros niveles del sistema educativo redunda en la cualificación y flexibilidad de los currículos; en el fortalecimiento de la educación para el trabajo (CEPAL, 2010, p. 223).

47 Subraya la CEPAL que: "la mayor igualdad en el ámbito de los derechos sociales permite una mayor igualdad en cuanto a la voz y la visibilidad políticas. Dicho de otro modo, una mayor integración al trabajo digno, a la educación de calidad, a la información y al conocimiento, y a las redes de protección e interacción sociales, permite mejorar la capacidad de los ciudadanos para la participación política", entre otras (CEPAL, 2010, p. 44).

48 El vínculo entre igualdad y ciudadanía no es genérico ni abstracto, conceptúa la CEPAL; este tiene que ver con: "Ciudadanía o igualdad de derechos, justicia social o igualdad sustantiva, y reconocimiento de la diversidad o igualdad en la diferencia, conceptos equiparables entre sí en significación e importancia" (CEPAL, 2010, p. 45). "El análisis de las disparidades y convergencias territoriales y regionales demuestra fuertes segmentaciones y rezagos en la productividad de las economías de los países, brechas intersectoriales o intra-sectoriales que se replican en las regiones y se trasmiten del aparato productivo a la sociedad. Con cierta regularidad el lugar de residencia de una persona determina su condición económica. Así, las desigualdades territoriales y sociales se entrelazan en una relación sistémica y dialéctica: el rezago en desarrollo humano, se explica por el rezago económico, este por el rezago laboral, ocasionado por el rezago educativo, y así en forma cíclica" (CEPAL, 2010, pp. 131-136). Por ejemplo, "cuando se aleja la flexibilidad laboral para perpetuar asimetrías contractuales, la misma deviene en precarización y deterioro de las condiciones 
En la evaluación de las políticas nacionales de educación superior efectuada por la OCDE y el Banco Mundial (2012) se afirma que, a medida que aumenta el optimismo económico, la sensación de seguridad y las oportunidades, los "colombianos necesitan nuevas y mejores competencias para responder a los nuevos retos y perspectivas de desarrollo"; sin embargo, es paradójico el bajo desempeño y mala calidad $^{49}$ del sistema educativo, dado que, según

de trabajo" (CEPAL, 2010, p. 174). La CEPAL cita a la OIT (2004, a) que identifica siete formas de seguridad laboral y económica que tienen que ver con el desarrollo y potenciación de las capacidades humanas, a saber: "seguridad de los ingresos, que se refiere al nivel y los mecanismos de pago de los ingresos laborales y los apoyos financieros que se perciben al perder un empleo; seguridad del mercado de trabajo, que se refiere a los niveles de ocupación que deberían aspirar a alcanzar el pleno empleo. Seguridad del empleo, que consiste en empleos permanentes, protegidos y de tiempo completo; seguridad del trabajo, que se refiere a los estándares de salud y protección en el puesto de trabajo, necesarios para evitar enfermedades y accidentes laborales; seguridad de las capacidades, que se refieren a la posibilidad de adquirir conocimientos y habilidades y poder aplicarlos en el trabajo; la seguridad del puesto del trabajo, que se refiere a la opción de desarrollar trayectorias laborales ascendentes, y seguridad de la representación, que se refiere a los niveles de organización y negociación colectiva" (CEPAL, 2010, p. 175).

49 "La calidad surge de la inversión continua en las cualificaciones de los docentes, en la investigación, surge de los esfuerzos de las personas comprometidas con la excelencia (OCDE-Banco Mundial, 2012). Además, la calidad tiene que ver con el aprovechamiento del "conocimiento avanzado, que es la materia propia con la cual trabajan las IES, genera competitividad y productividad. La migración del conocimiento hace que se globalice la economía basada en este, estimula la competencia, eleva y globaliza el nivel de las competencias profesionales que requiere la movilidad de la educación superior transfronteriza (Brunner y Hurtado, 2011, pp. 22-23). Señala que el mayor desafío para las universidades iberoamericanas es formar el "capital humano" de alta calidad que lidere la "cohesión e integración social, el crecimiento y competitividad, e institucionalidad para la gobernanza" (Brunner y Hurtado, 2011, p. 50), y destaca cómo algunos de los países, entre ellos Colombia, forman parte de los más desiguales e inequitativos del mundo (Brunner y Hurtado, 2011, p. 51). “En síntesis, los problemas de acceso, equidad, calidad y eficiencia del sistema de educación del país se mantienen a pesar de los esfuerzos por ampliar la cobertura e implementar procesos de aseguramiento de la calidad" (p. 89). Poco antes de 2005 se inicia la expansión de la educación superior en Colombia, a causa de la ampliación de la cobertura de la educación media, por la demanda de profesionales y trabajadores cualificados, según las pautas trazadas por la Revolución educativa del Gobierno de entonces (Brunner y Hurtado, 2011, pp. 190-191). "Se asiste a una profesionalización cada vez más exigente de la carrera docente que, poco a poco incluye como condición básica el doctorado" (Brunner y Hurtado, 2011, p. 223). Los analistas utilizan la categoría "capital humano" para hacer énfasis en el papel de la educación superior, sobre todo en "la formación de profesionales competentes en la gestión del conocimiento avanzado, de científicos e ingenieros capaces de participar en la producción del nuevo conocimiento" que sostiene, amplía y renueva el "capital humano". Y utilizan variables como: tasa de graduación por país y en la región; organización de los procesos formativos; eficiencia interna de los procesos formativos; distribución la evaluación de las políticas, se "olvidó de centrarse en las necesidades de los estudiantes, los graduados y la sociedad en que trabajan", asunto que debería ser el eje vertebrador del camino hacia la calidad fruto de la inversión en cualificación docente, investigación, uso constante, creativo e innovador del sistema nacional de datos ${ }^{50}$ y de los criterios de certificación centrada en resultados, trasparencia y responsabilidad social ${ }^{51}$.

Las instituciones de educación superior que comparan los resultados de las pruebas Saber 11 con los resultados de las pruebas Saber Pro identifican avances, aportes y falencias en la formación de capacidades genéricas y específicas, actualizan la oferta curricular, implementan procesos de admisión bajo criterios realistas, claros y precisos, y adoptan enfoques pedagógicos que posibilitan el desarrollo hu-

profesional de los graduados; inserción laboral, y gestión de la información sobre empleabilidad. Las comparaciones de indicadores se establecen entre los años 2007 y 2011. Se destaca el problema de pertinencia de la oferta académica, un alto porcentaje de universidades aún no sintonizan con la necesidad de ubicar el país en el escenario de la producción de conocimiento, innovación y economía mundial, se ocupan más del desarrollo de lo disciplinar. Se justifican haciendo hincapié en lo básico con detrimento de lo aplicado. En el país no hay coincidencia entre la estructura ocupacional y la oferta educativa (Brunner y Hurtado, 2011, pp. 239-244, 265-266).

50 Llama la atención el poco uso que se hace en las instituciones de educación superior del sistema nacional de datos para mejorar los modelos educativos, para determinar el impacto de los programas que ofrecen en la formación de los estudiantes o para indagar por el tipo de capacidades y competencias que requiere el medio laboral (OCDE y Banco Mundial, 2012, p. 83).

51 El equipo evaluador encontró varias fortalezas en el sistema de educación superior: el aumento de la cobertura en los últimos diez años, políticas coherentes, planeadas y sólidas, apoyo a la equidad y al acceso educativo, sistema de evaluación y calidad eficaz y valiosa. Además, espera que se simplifique la gama y jerarquía de los títulos que ofrece, se enfatice en la calidad y la pertinencia de los programas que se ofrecen, se reduzcan las disparidades de los costos educativos entre regiones, se disminuya la deserción, se cualifique la educación secundaria en beneficio de la educación superior y los consejos directivos y administrativos de las universidades adopten los objetivos nacionales en la toma de decisiones centrándose en el bien público. Así mismo es oportuno adoptar estrategias de internacionalización, aprendizaje de un segundo idioma y movilidad del personal educativo (OCDE y Banco Mundial, 2012, pp. 13-19). Dentro del análisis general el equipo evaluador encontró que: "las instituciones de educación superior son muy conscientes de su autonomía, pero menos conscientes de su responsabilidad a la hora de contribuir en el cumplimiento de objetivos nacionales"; "los estándares académicos de los estudiantes que entran en la educación superior son en general bajos comparados con otros países"; las instituciones a duras penas conocen las competencias que requieren los empleadores; la internacionalización es baja al igual que la investigación (OCDE y Banco Mundial, 2012, pp. 57-60 y 80-85). 


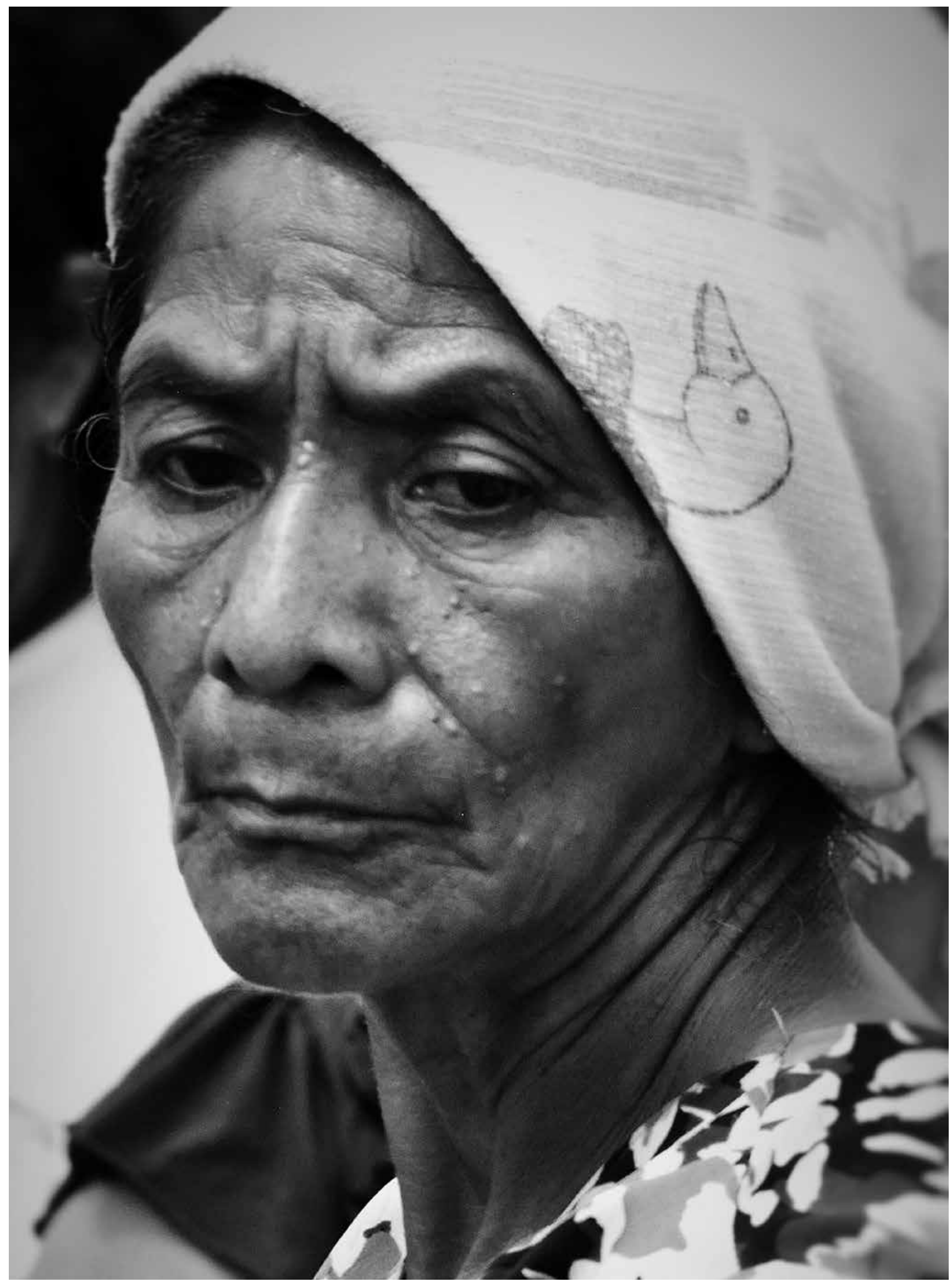


mano integral de los estudiantes y disminuyen la deserción ${ }^{52}$. Pero, sobre todo acuerdan con el nivel anterior de escolaridad las estrategias para suplir el deficiente nivel de escolaridad y la falta de preparación de los estudiantes para ingresar a la universidad ${ }^{53}$ : se establecen cursospuente, se fortalecen los primeros semestres con estrategias de acompañamiento personalizado, se diseñan programas complementarios vía internet, paralelos a los aprendizajes de los grados 10 y 11 , y se oferta asesoramiento que les permita a los estudiantes acertar en sus decisiones.

El análisis de calidad y pertinencia de la educación superior se efectúa de cara a su contribución al índice de competitividad global 2011-1254, a la "creación de capital humano" de alto nivel científico, a la diversificación incluyente de la oferta formativa orientada al trabajo, a la presencia y permanencia de académicos de excelente nivel pedagógico e investigativo sintonizados con los proyectos educativos que garanticen formación integral en "competen-

52 Aun así, el equipo de expertos considera que el diseño y resultados de la prueba Saber 11 es poco confiable y que esta debe ser complementada a través de procesos paralelos utilizados en las instituciones de educación superior (OCDE y Banco Mundial, 2012, p. 111). De igual manera, la deserción, la falta de acceso y la iniquidad impiden la realización de las expectativas de formación de muchos jóvenes, generan pérdida de inversión y dificultan el desarrollo humano individual y colectivo (OCDE y Banco Mundial, 2012, p. 124). Sin embargo, hace falta investigar la correlación entre deserción y baja calidad docente.

53 Al evaluar las posibilidades de acceso de los estudiante y de equidad del sistema educativo colombiano, los analistas concuerdan en que: "el problema más importante que se enfrenta es el de la falta de preparación para la universidad de tantos colombianos cuando terminan la secundaria, porque: la escolarización no es suficiente y aunque mejoren al ingresar el desempeño es bajo comparado con países semejantes; los colombianos tienen menos conocimientos que sus homólogos de referencia; a los quince años carecen de competencias básicas... se limita el potencial de los estudiantes para aprender y seguir el ritmo de la educación superior, se incrementa el índice de deserción sobre todo en los primeros semestres, con el agravante de que es mayor si los estudiantes provienen de colegios públicos" (OCDE y Banco Mundial, 2012, p. 113).

54 Los indicadores y estándares de medición del Índice Global de Competitividad los establece la OCDE y el Foro Mundial (OCDE y Banco Mundial, 2012, p. 158). Si bien es cierto que dicho análisis es fuertemente economicista, también enfatiza en el mejoramiento de la calidad de la educación que se basa en la creación de capacidades y competencias fundamentadas en conocimientos, habilidades $y$ actitudes profesionales $y$, que contribuyen a la economía, el desarrollo social y económico del país (OCDE y Banco Mundial, 2012, pp. 157-158). cias disciplinares específicas, competencias genéricas, aprendizaje en contexto y cadena de valor agregado" ${ }^{\prime 55}$. Aunque crece el interés de las IES para actualizar los currículos con base en capacidades y competencias, la demanda internacional insiste en atender a "el pensamiento crítico, el razonamiento analítico, la resolución de problemas, la facilidad de comunicación escrita, la capacidad de liderazgo y la capacidad de trabajo en equipo"56, estimuladas por la participación cualificada del personal académico.

En el Acuerdo por lo Superior 2034 se mancomunan todos los esfuerzos de los diversos sectores, actores e intereses para dialogar, acordar y resignificar la naturaleza, el papel y los fines de la educación superior hoy ${ }^{57}$. La perspectiva orientadora acerca de la educación como camino humanizador, vital y espiritual llevado a cabo por medio de la "religación ética", aporta luces al enfoque de desarrollo de las capacidades, en tanto que hace evidente la

55 Según aclara el estudio "Las competencias específicas se refieren al campo de conocimiento elegido por el estudiante. El aprendizaje en contexto incluye los contextos culturales, físicos y de comportamiento, mientras que la cadena de valor agregado se centra en "lo que un estudiante tiene al comenzar el programa y lo que se lleva con él o ella al terminar..." (OCDE y Banco Mundial, 2012, pp. 170-171). Diagnosticar la pertinencia, la empleabilidad de los egresados y la capacidad de respuesta de las IES a las necesidades de los empresarios, contribuye a la actualización permanente de las competencias genéricas, de las prácticas empresariales y a la identificación de rutas de mejoramiento de los aprendizajes (OCDE y Banco Mundial, 2012, pp. 187-188).

56 En algunas universidades las competencias se actualizan de acuerdo con la contribución de los empresarios, los egresados y los centros internacionales de investigación y desarrollo profesional laboral (OCDE y Banco Mundial, 2012, pp. 170-172). En relación con el aseguramiento de la calidad del sistema de educación superior en Colombia, además de mejorar la confiabilidad de los exámenes SABER 11 y SABER PRO, es posible medir el valor agregado que aportan los programas universitarios utilizando el primero como medida de entrada y el SABER PRO como evaluación de las destrezas profesionales básicas. De igual manera, evaluados los niveles de desempeño, se ajustan los procesos pedagógicos $y$, las competencias por módulos de oferta universitaria (OCDE y Banco Mundial, 2012, pp. 215-217).

57 Aunque el esfuerzo encomiable de los economistas, juristas y sociólogos estructuralistas y sistémicos salta a la vista, se requiere dejar claro que la finalidad del sistema educativo mirado desde la complejidad es cualitativo, a saber: la persona éticamente religada consigo misma, con los próximos, con la familia, con la sociedad, la comunidad, con la humanidad y con el cosmos. "Las desigualdades diagnosticadas no son solo de naturaleza cuantitativa, afirma Morin, de verdad son inicuas, pero lo lamentablemente dañino es que se perpetúan contra los más pobres y excluidos" (Acuerdo por lo Superior 2034. Propuesta de Política Pública para la Excelencia de la Educación Superior en Colombia, 2014, pp. 6-12). 
complejidad de las mismas ${ }^{58}$ y la necesidad de que se articulen desde el sujeto. Al respecto, el trabajo de las mesas de diálogo que debatieron y contribuyeron en la construcción de esta política concluyeron que: "el sistema de educación superior se encuentra consolidado estructural, normativa y organizativamente, pero se halla desarticulado", es decir, desligado de las luchas, las necesidades, los intereses y las expectativas de los individuos, la sociedad y la naturaleza. Lo que evidencia que no solo es la sostenibilidad financiera la debilidad del sistema educativo. $Y$ que por el contrario el "sentido, la orientación y la finalidad humana son el mayor desafío que enfrenta. Por consiguiente, la misión, visión y medios deberían articularse en torno a la búsqueda del "bien vivir", religado, abierto, equitativo y justo".

En conclusión, las cuestiones que deberían jalonar el enfoque educativo universitario centrado en el desarrollo humano, concuerdan con los interrogantes formulados por la comisión de sabios en el documento Colombia al filo de la oportunidad (1995): ¿Para qué?, ¿para quién educar?, y ¿cómo hacerlo?; asunto ético, político y cultural que es indispensable abordar también desde lo económico, financiero y estratégico. En cuanto a cómo hacerlo, Gabriel García Márquez y Edgar Morin concuerdan en que los procesos y mediaciones que se adopten, como el diálogo socrático y la compresión imaginativa, deben contribuir a que las personas sean autocríticas y conscientes de las cegueras, riesgos

58 En el lenguaje de la complejidad se entiende lo espiritual como construcción consciente, responsable y autónoma del sentido de vida por medio de la articulación entre materia y espíritu, medios y fines, sujeto y objeto. En el centro del asunto se ubica el "modelo antropológico" que no asume al sujeto con todas sus tensiones, dimensiones y contradicciones ni a la sociedad en su dinámica de interacción con los sujetos, la cultura y los objetos y, menos aún las implicaciones cósmicas de la naturaleza en la vida de las personas y los grupos humanos; por medio de la "religación consigo mismo (ideas, fantasmas, sensaciones, ideales, compromisos, etc.), religación con el prójimo (unicidad-(unicidad-diversidad indispensable al doble mecanismo del yo),religación con los suyos (lazos familiares y afectivos), religación con la comunidad (lazos solidarios), religación con la sociedad (lazos históricos y sociopolíticos), religación con la humanidad (lazos planetarios) y, en última y primera instancia, religación cósmica (lazos con las fuentes originales del universo)" (Tomado del Prólogo escrito por Edgar Morin para el Acuerdo por lo Superior 2034, 2014, pp. 6-12). de error, enajenaciones y efectos que las ideas, tradiciones, creencias y sentimientos que tienen sobre el conocimiento; a fin de que caigan en cuenta de las mentiras propias, las corrijan y busquen la verdad con flexibilidad, apertura y asiduidad, sin que las ideas los destruyan y sin que haya que destruir a los otros por sus ideas.

Edgar Morin también sugiere que en relación con el aprovechamiento óptimo y pertinente de la información se capacite en "inteligencia general", trans-disciplinar y dialógica que contribuya a la identificación, planteamiento y solución de los problemas claves, contextualizándolos desde la complejidad y la racionalidad. Insiste en que la educación humanizante plantea preguntas axiales, complejas y contextuales: ¿quiénes somos?, ¿dónde estamos?, ¿de dónde venimos?, y ¿a dónde vamos?; interrogantes que apuntan a la formación de la comprensión humana, a la capacidad de diferenciar e integrar cerebro-mente-cultura, razón-afecto-impulso e individuo-sociedad-especie ${ }^{59}$.

Adoptar la perspectiva planetaria o terrenal en la propuesta de desarrollo humano, implica para la educación superior formar lo intelectual, afectivo y ético en "identidad planetaria"; además de replantear los discursos tradicionales sobre antropología, ecología, ciencia y espiritualidad, e incluir modelos económicos sustentables ${ }^{60}$.

En un mundo precario, altamente vulnerable y en permanente transformación se hace prioritario educar para "enfrentar las incertidumbres", asimilarlas vitalmente confrontándolas con los propios conocimientos, con las certezas "eternas", con los marcos comportamentales, para modificar las posturas inflexibles, ganar en tole-

59 Para Morin, la formación de la conciencia planetaria y de las capacidades para el cuidado de la tierra, constituye a su juicio el reto más significativo en la educación. A juicio de quien escribe, los bucles propuestos por Morin contribuyen a que al diseñar propuestas de investigación con enfoque complejo se tengan en cuenta sus componentes, la identificación de las preguntas claves, la contextualización, la dialogicidad, transdiciplinar y ética (CESU, 2014, p. 9).

60 Tarea de implicaciones éticas, epistémicas y culturales a fin de que la misión de la universidad se lleve a cabo de cara a los avances, tensiones y conflictos actuales (CESU, 2014, p. 10). 
rancia y comprensión, tanto en lo interpersonal e intergrupal, como a escala planetaria ${ }^{61}$. Pues la incomprensión es reduccionista, egoísta y etnocentrista; el modo político de la comprensión es la democracia. De las relaciones entre individuos sociedad y especie emerge la necesidad de una ética del género humano, concluye Morin (2014, p. 12).

\section{El Problema}

A juicio de los expertos la prioridad de la oferta educativa superior es la transformación del ethos socio-cultural colombiano, la construcción de civilidad en torno al proyecto común delineado en la Carta Política de 1991, la igualdad, la democratización del conocimiento científico, la justicia, y la convivencia en paz. Propósito imposible de alcanzar si no se atiende de manera creativa, pertinente, y cualificada al desarrollo integral de las capacidades de las personas, a las exigencias de la sociedad del conocimiento, a los desafíos que la globalización suscita y, sobre todo, a la experiencia real de frustración, exclusión y violencia que parece perpetuarse por medio de un sistema educativo de baja calidad, adoctrinador, endógeno y descontextualizado ${ }^{62}$.

61 En la propuesta sobre Los siete saberes necesarios para la educación del futuro, Edgar Morin (1999) lleva a cabo un pormenorizado análisis de los contenidos, significados y capacidades que comprende cada uno de los siete saberes esbozados, al modo de respuesta sobre el modo de llevar a cabo la alternativa formativa de "desarrollo humano" en respuesta a la pregunta ¿para qué? y ¿para quién educar? El Acuerdo por lo superior 2034 del CESU recoge en el prólogo un resumen sobre "Los siete saberes básicos", síntesis elaborada por dicho autor.

62 Las crisis reiterativas de la universidad sobre su misión o centralidad social, sobre su validez y legitimidad, y acerca de estructura administrativa y de gestión, reflejan las crisis humanas, sociales contextuales, y los múltiples intereses que, rondan su quehacer e importancia cultural. El impacto de la globalización neoliberal conduce a que la crisis se conciba en términos economicistas, tecnócratas y de planeación, y a que las soluciones que se plantean, simplistas y a corto plazo, adolezcan de legitimidad y significación en cuanto a formación integral, de pregrado y posgrado, centrada en la investigación, en el conocimiento de los contextos socioculturales, en la trans-disciplinariedad, y en la ética y científica de los docentes. Después, de subrayar algunas de las características que han tenido las crisis de la universidad en Europa y en Latinoamérica, durante los últimos siglos, Sergio de Zubiría plantea algunos dilemas que se deben afrontar para promover el cambio y la pertinencia de la universidad en nuestro país, a saber: priorización del análisis de pertinencia previo al planteamiento de las alternativas pedagógicas; concreción de lo que se entiende como "fina-
En palabras de Nussbaum (2011), el neocapitalismo global, utilitarista y rentable, a costa de tratar a las personas como medios, empuja el desarrollo de las naciones hacia lo económico de una manera tal que equipara crecimiento económico con desarrollo humano, crecimiento del producto interno bruto per cápita $(\mathrm{PIB})^{63}$ con mejoramiento en las condiciones de vida de la mayoría, y rendimiento financiero con consolidación de la democracia. Aunque la ciencia, la tecnología y la economía son indispensables para responder a las necesidades de las personas y a los fines de la democracia, las presiones de la competitividad financiera sobre la educación superior socavan la naturaleza y misión de la institución universitaria, que se ocupa también de otros fines como: "desarrollar el pensamiento crítico, trascender las lealtades nacionales, construir ciudadanos del mundo, crecer en imaginación compasiva, religarse a sí mismo, a los otros y a la realidad"64.

lidad social", y de los términos en que se establecen los vínculos universidad, empresa y estado; salvaguarda de la autonomía universitaria dentro de las exigencias de promoción de los derechos consagrados en la carta política; diversificación de las respuestas sociales, según la pluralidad de actores, pueblos y necesidades; fortalecimiento de la democracia a través de la participación democrática universitaria; consolidación del enfoque de desarrollo humano, ético, intersubjetivo, crítico y ecológico, antes de que al modelo de "competencias" eficientistas; énfasis en la pluralidad sociocultural antes que la homogenización dominante Véase: Sergio de Zubiría. La pertinencia social de la universidad. En: Orozco. Colombia. Bogotá. Ediciones Uniandes.

63 Sobre lo que el producto interno informa acerca del desarrollo humano y su correlación con el crecimiento económico, el estudio comparativo entre India y China, en el cual el economista sostiene que aunque el crecimiento económico contribuya a mejorar la calidad, el PIB no refleja la correlación entre crecimiento y calidad de vida integral, véase Amartya Sen, (2011, pp. 4-7).

64 Defiende la filósofa el papel de las humanidades en la construcción de la democracia moderna, la mediación de estas en el desarrollo de capacidades humanas que como el pensamiento crítico, el análisis lógico y la imaginación comprensiva contribuyen en la educación integradora. Deja en claro que su aporte no va en contra del papel de las ciencias empíricas ni desconoce para nada la contribución de estas en el mejoramiento de la calidad de vida de las personas, lo que le inquieta es el modo pernicioso como las presiones económicas sesgan los contenidos de los programas académicos, los enfoques pedagógicos, las metodologías de enseñanza; desconocen el influjo de la multiculturalidad de los ciudadanos en las decisiones democráticas que los afectan, y en consecuencia la necesidad de que el sistema educativo los prepare para tal fin, promoviendo capacidades para la interdependencia y la civilidad. Estos planteamientos los recoge Martha Nussbaum (2011, pp. 19-31). Reflexiones que vienen desde Las mujeres y el desarrollo humano (2000). Retomando el lenguaje de la complejidad se puede colegir que las capacidades planteadas por Nussbaum, son concreciones de religantes de las potencialidades de ser y ha- 
Equiparar progreso con rendimiento del PIB, y crecimiento económico con crecimiento financiero, sin que se asegure la redistribución de los beneficios en favor de los que viven por debajo del umbral de satisfacción de las necesidades básicas es "importar muy poco los otros aspectos que conforman la calidad de vida" ${ }^{65}$ y hacen posible la democracia. Las variables económicas, financieras y rentistas no reflejan la gran complejidad, dinamismo y diversidad de la vida humana real: el aumento en la producción no mide la calidad de vida de todas las personas, las desigualdades persisten, sobre todo en sectores como la salud y la educación, y las diferencias se acrecientan cuando se trata de minorías consuetudinariamente excluidas.

Si bien es cierto que la concepción limitada del desarrollo se preocupa, sobre todo, por el crecimiento económico, también es cierto que si no hay democracia y distribución de las riquezas, se llega a paradojas tan injustas como las que se viven en países altamente ricos e inhumanamente excluyentes. Se requiere de jóvenes formados para la democracia, la creatividad y las artes, y al mismo tiempo, capaces de generar empresas sustentables y socialmente responsables. El modelo rentista no responde a las expectativas de mejoramiento en salud, educación, y sustentabilidad ecológica ${ }^{66}$.

La educación universitaria debería preocuparse por formar personas que se interesen en

cer de cada persona (Morin, 2034, pp. 6-11).

65 El paradigma del "crecimiento económico" es reduccionista y monofocal, pues: "crecimiento económico no equivale a producir democracia ni a generar una población sana, comprometida y formada que disponga de oportunidades para una buena calidad de vida en todas las clases sociales" Nussbaum (2011, p. 36).

66 En las mismas palabras de la filósofa: "producir rentabilidad económica no equivale a producir democracia ni personas sanas, educadas, creativas y justas. El interés por la economía, la administración, las técnicas, la información, y las ingenierías puede ayudar al crecimiento económico de los países, aun acrecentando los índices de desigualdad en términos alarmantes. Ocuparse del crecimiento económico, también debería incluir el ocuparse de la historia económica de la injusticia social, y de sus efectos en las minorías raciales, culturales, en las mujeres, y en las poblaciones menos educadas, de aquí que el pensamiento reflexivo y crítico sobre este asunto no sea de mucho interés en la formación de capacidades económicas, administrativas y gerenciales, y por el contrario se enfatice en el logro de bienestar y satisfacción (Nussbaum, 2011, pp. 33-49). la reflexión crítica acerca de los problemas que afectan al país, asuman y reconozcan a los otros "como fines en sí mismos", prevean y analicen los efectos que las políticas internacionales tienen sobre otros países, se preocupen por comprender imaginativamente las historias de vida de las personas que sufren exclusión o que luchan por ser capaces de ser ellas mismas, y así construyen el bien común de la nación ${ }^{67}$.

Los proyectos educativos de un alto porcentaje de instituciones de educación superior subrayan la centralidad de los estudiantes y el propósito de contribuir a su formación de manera integral. Sin embargo, en los contenidos curriculares no se asumen las necesidades de los contextos en que viven estos, ni las cualidades individuales que poseen, y mucho menos sus expectativas de realización personal ${ }^{68}$. De igual manera, no se constata la coherencia suficiente entre "formación integral", modelo biopsicosocial y fines de la educación, ni la congruencia indispensable entre el marco ideológico institucional y la propuesta pedagógica, curricular y evaluativa, y en suma la consistencia requerida entre macro-estructura, estructura y prácticas docentes efectivas universitarias.

Para que la educación responda a los problemas de las personas y contribuya a la construcción de vidas humanas significativas y gratificantes necesita ocuparse del análisis de los marcos culturales de exclusión de los estudiantes y docentes, entre otros, e identificar las causas generadoras de la inequidad y los desequili-

67 Además, de las anteriores aptitudes Nussbaum (2011, pp. 48-49) cree que cada propuesta educativa debería considerar las más acordes con las necesidades de sus estudiantes.

68 Soslayan debates tan cruciales para las personas y para el bien común del país, como el del estatus de la educación superior dentro del marco del Estado social de derecho, pues la salvaguarda de los derechos fundamentales impide que sean solo los méritos el criterio para acceder a la educación de tercer nivel, en un país caracterizado de vieja data por la desigualdad, las asimetrías económicas, la corrupción, y la jerarquización social es ingenuo pensar que el mérito no esté condicionado por dichos factores. El solo hecho de orientar la educación solo a la productividad económica, al posicionamiento rentista, sin que se insista con igual énfasis en el desarrollo de las demás dimensiones humanas, sesga el derecho de a la educación hacia el disfrute de un bien, y no a la garantía de un derecho de todos y todas (Arango (2014, pp. 201-250) (Orozco, 2014). 
brios sociales; de esa manera contribuiría a que la vida fuera más valiosa, libre y civilizada ${ }^{69}$.

\section{El desarrollo humano, horizonte de formación integral en capacidades y competencias}

\section{El hecho de que muchas personas y grupos} minoritarios malogren sus capacidades humanas, sean excluidos de la participación, vean maltrecha la realización, prosperidad e historia de vida a causa de la inequidad y desigualdad política ${ }^{70}$, económica, cultural y religiosa en que han nacido, y a pesar de que dichas limitantes y condicionamientos sean capaces de

69 El uso reduccionista del PIB que equipara calidad de vida humana con incremento en producción e integra variables econométricas con otros tipos de variables que no caben dentro de esta; se olvida que mejorar la calidad de vida es un asunto complejo, que tiene que ver con lo ¿qué las personas son capaces de ser y hacer? Por eso los modelos econométricos agenciados por el Fondo Monetario Internacional y el Banco Mundial, aunque sean fáciles de medir como el PIB, permitan la comparación entre países y señalen la senda de crecimiento correcta, no evidencian hasta dónde los beneficios económicos revierten en favor de los más pobres, sobre todo en salud y educación. Dentro de las grandes economías mundiales existen, también grandes cinturones de miseria. Por eso el PIB per cápita no es el indicador más adecuado para reflejar la situación de calidad de vida de un país, los enfoques que miden el promedio nacional no prestan atención a la distribución social y a las desigualdades internas de un país. Un solo número homogeniza aspectos de la vida humana claramente diferentes (Nussbaum, 2012, pp. 13-24 y 68-72,). También, véase de la misma autora, el análisis que hace acerca de los puntos comunes y las diferencias de su propuesta de capacidades, con los aportes de John Rawls, sobre todo en lo concerniente a los retos planteados por "la deficiencia y la discapacidad de las personas", dado que conducen a preguntarse ¿Para quién están pensados los principios básicos de la sociedad?; de igual manera, a responder por el "trato justo con los animales no humanos y la pertenencia a la especie", y sobre todo por el aseguramiento de la "justicia universal" y las nacionalidades, pues para la filósofa desde el "contractualismo", propuesto por Rawls, lo que se busca es el beneficio y la ventaja mutua, el orden que propugna el contractualismo es para garantizar una sociedad autosuficiente, y no una sociedad interdependiente que promueve la benevolencia universal y general como lo exige el enfoque de capacidades humanas (Nussbaum, 2007b, pp. 28-35).

70 Ver el informe de la CEPAL (2010) analizado con anterioridad en este artículo, sobre la desigualdad en Latinoamérica. Los índices y variables reflejan un panorama desalentador sobre la calidad de la educación en Colombia, por eso el debate no hay que dejarlo solo a los economistas ni solo a los juristas o estudiosos sociales, hay que abrirlo por sobre todo a los estudiantes y maestros, pues no se trata solo de maximizar la renta ni elevar la utilidad económica, la meta no es el lucro ni la satisfacción, es construir otro ethos civilizatorio que responda a la complejidad de la experiencia humana, y que posibilite responder a las siguientes preguntas: ¿cómo puedo mejorar mi vida? y ¿cómo debería obrar para contribuir al mejoramiento de la vida de los otros? (Nussbaum, 2000, p. 390). Ver prólogo de Edgar Morin en Acuerdo por lo superior 2034 (2014, pp. 6-11). generar cambios y posibilidades de desarrollo humano alternativo es la base de la propuesta del desarrollo de capacidades ${ }^{71}$ como opción de política educativa para superar la inequidad estructural. Dado que nos ubicamos en los primeros lugares de Latinoamérica y del mundo como sociedad excluyente e inequitativa, situación que cuestiona la responsabilidad y el liderazgo de la educación superior en la oferta de alternativas de trasformación socio-cultural y económica incluyentes ${ }^{72 .}$

Optar por el enfoque de desarrollo humano como propuesta para el diseño de las políticas institucionales, implica partir de la realidad, del acopio de experiencias frustrantes y gratificantes, de la toma de conciencia de los prejuicios y pre-comprensiones que subyacen en las tradi-

71 En su trabajo de varios años con las mujeres de la India, Martha Nussbaum constata el trato discriminatorio que se les infringe por lo que son, pues no pueden expresar sus sentimientos, llevar al máximo la realización de sus capacidades y protagonizar sus existencias simplemente porque son mujeres. Y porque el afán político del Estado indio se orienta prioritariamente al desarrollo económico dentro de los cánones del capitalismo neoliberal, de la sociedad de bienestar y de rendimiento financiero (Nussbaum, 2000, pp. 387-388). En el proceso de formulación y validación de la lista de capacidades centrales con base en la teoría del desarrollo humano, la filósofa la confronta con otras teorías filosóficopolíticas, preguntándose si son satisfactorias las respuestas de estas a tres problemas críticos sobre: (1) La garantía de justicia con las personas discapacitadas, (2) la universalización de la justicia a todas las personas del mundo y, (3) los principios que aplican en relación con el trato justo con los animales no humanos. Considera que el contractualismo de John Rawls aporta elementos valiosos, pero que se queda corto frente a la garantía de derechos de los discapacitados, y del trato justo para con los animales no humanos; de igual manera, el utilitarismo y el estado de bienestar se quedan cortos frente a los derechos de la mujer y las minorías. Valora la idea de liberalismo político y de consenso entrecruzado, pero critica la separación que perpetúan entre lo público y lo privado y el descuido con los mecanismos para asegurar la igualdad y dignidad con los discapacitados, si bien el "contractualismo" se satisface con el establecimiento de una sociedad política sometida a la ley, fundamentada en la equidad y la igualdad, y el rechazo a toda hegemonía utilitarista, queda corto frente a la universalización de la justicia para todos en el mundo. También, el enfoque de beneficio mutuo debe avanzar más allá de la búsqueda utilitarista de los propios intereses (Nussbaum, 2007a, pp.18-38 y 163-166). Otro de los mecanismos de la ideología dominante para mantener los privilegios, sostener el orden y perpetuarse en el poder es la dicotomía: normal vs anormal, mayoría vs minoría, correcto vs incorrecto, apropiado e inapropiado. El rechazo de lo anormal es una estratagema de defensa del orden amenazado. Por eso, el desarrollo de capacidades como la compasión, la reciprocidad y la protección favorece la superación de los generadores de violencia (Bauman, 2013, pp. 85-90).

72 A juicio de M. Nussbaum (2000, p. 387), el desarrollo humano debería ser un criterio suficiente para evaluar la calidad del sistema educativo. 


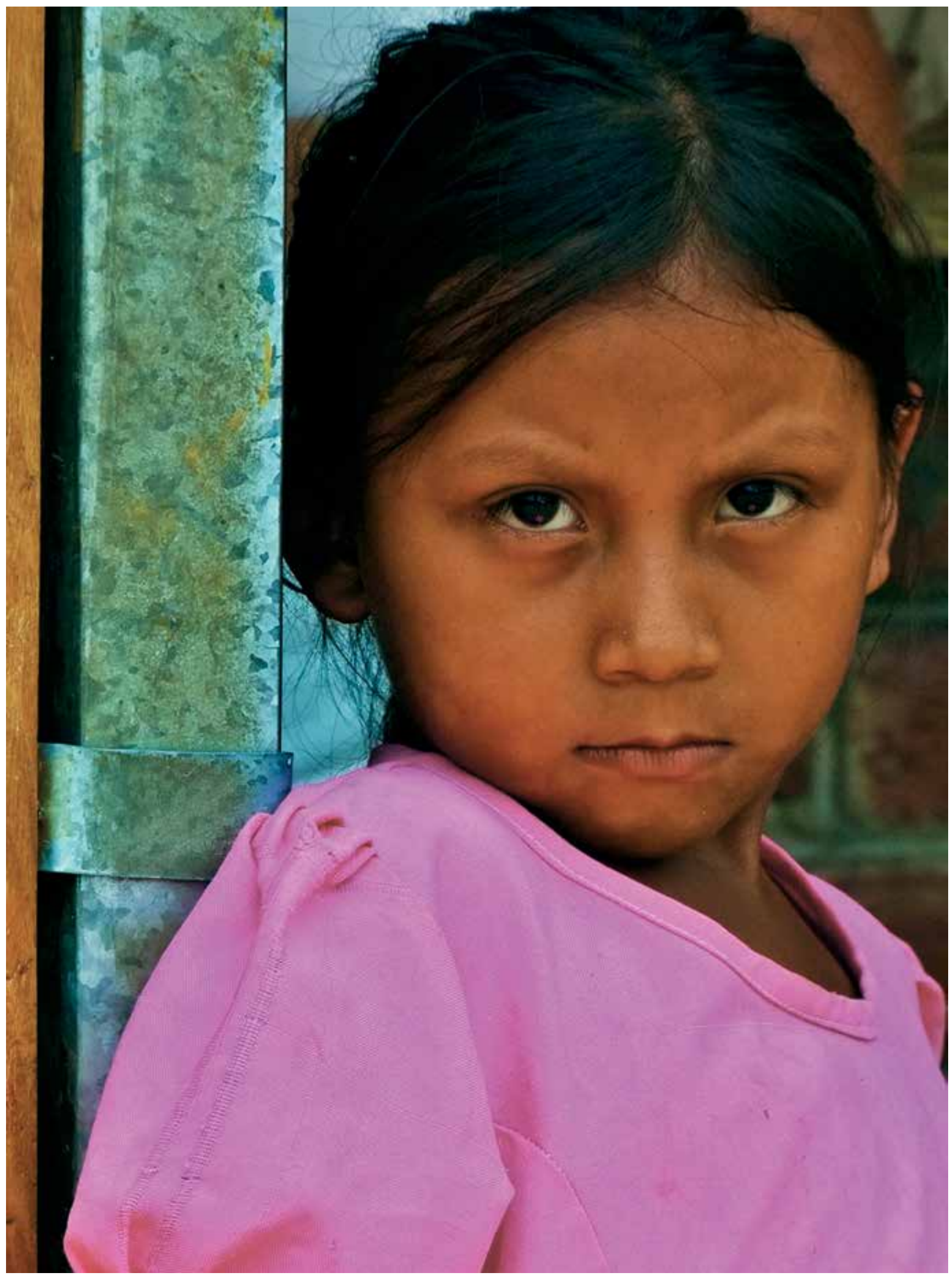


ciones, valores, experiencias, y modos concretos de representación del mundo socio-cultural que instrumentaliza e incapacita a las personas ${ }^{73}$.

\subsection{El enfoque de las capacidades humanas $^{74}$}

Para M. Nussbaum (2012) las capacidades es aquello que las personas responden cuando se les pregunta en un momento dado ¿qué son

73 Los estudios citados al comienzo del presente escrito demuestran hasta dónde la discriminación por género, condición social, procedencia, raza e impacto de la violencia frenan el desarrollo humano de las minorías sociales, de las mujeres y los niños. El enfoque de desarrollo humano trata de superar las alternativas ingenuas, neutrales y funcionalistas que hacen del PIB la medida más adecuada del desarrollo de las personas. (Nussbaum, 2000, pp. 17-31).

74 El enfoque de capacidades humanas lo inician Mahbub UI Hag y Amartya Sen para contribuir con el diseño de políticas nacionales orientadas a la superación de las desigualdades sociales y la iniquidad reiterativa contra los grupos excluidos. Desde 1990 las Naciones Unidas definen el desarrollo humano como: "un proceso que ofrece a las personas mayores oportunidades de libertad, salud y educación y disfrutar de condiciones de vida digna. Aclara que es un abanico de dimensiones, capacidades, libertades políticas y derechos humanos. Supone la expresión de la libertad de las personas para vivir una vida prolongada, saludable y creativa; perseguir objetivos que ellas mismas consideren valorables y participar activamente en el desarrollo sostenible" El índice de desarrollo humano se compone de tres dimensiones, salud, educación y estándar de vida; y cuatro indicadores (ONU, 2010). M. Nussbaum se adhiere en términos generales a la propuesta de Sen, sobre todo a la postura común de distanciarse del enfoque de bienestar y satisfacción, así como del de utilidad y renta; se encuentran también al preguntarse ¿qué es lo que la gente es capaz de ser y de hacer? Pero, se diferencian al acentuar la dimensión individual del desarrollo humano, en tanto desarrollo de capacidades para ser y hacer, centradas en la igualdad y dignidad de las personas, a quienes se les debe asegurar un umbral básico exigible de satisfacción, y relación con el énfasis en lo colectivo comunitario que hace Sen de las capacidades. Cabe anotar que Sen no presenta una lista de capacidades centrales. En cambio M. Nussbaum ofrece un marco conceptual robusto, articulado con principios básicos, soluciones y descripción del umbral mínimo para cada una de las capacidades. Demuestra y acepta Nussbaum la contribución del contractualismo de John Rawls a su propuesta de capacidades para el desarrollo humano, sin embargo, subraya las diferencias y aspectos en los cuales se distancia de este. La filosofa destaca la actualidad de los aportes de Aristóteles y de los estoicos romanos con relación al concepto de dignidad e igualdad humanas; de Kant toma el concepto de la persona con "fin en sí misma", y de John Rawls lo relacionado con el "consenso traslapado", y con base en los aportes anteriores estructura el "principio de la capacidad de cada "persona como "fin en sí misma" (Nussbaum, 2000, pp. 3233). El enfoque de capacidades o potencialidades humanas es una propuesta ética, basado en la dignidad e igualdad de las personas; parte de las necesidades básicas de las personas se orienta por los derechos humanos y los concreta en capacidades de desarrollo individual, pero en contexto y con fines comunitarios (Nussbaum, 2000 , pp. 32-42). El enfoque de capacidades se basa en la experiencia que fija unos resultados y luego diseña unos procedimientos para alcanzar los resultados propuestos (Nussbaum, 2007, pp. 42-43 y 93$)$. capaces de ser y de hacer? Además, considera que son constitutivas de la calidad de vida de las personas, plurales, cualitativamente distintas e irreductibles entre sí; se pueden utilizar para evaluar la calidad de vida y el estado de aplicación de la justicia social, tanto en el caso individual como colectivo. En cuanto a oportunidades que demandan autodeterminación y libertad, contribuyen a identificar las dinámicas incapacitantes que atentan contra la calidad de vida de las personas ${ }^{75}$.

Para los analistas de la situación social y educativa del país, transformar el ethos cultural conlleva identificar y poner fin a las dinámicas connaturalizadas que reproducen ideologías y estructuras de exclusión y desigualdad, trasformando los contextos socio-culturales en escenarios para la confrontación dialógica y el debate ético-civilizado, para el funcionamiento diferenciado de las capacidades, y para la concreción de los derechos básicos por medio de estas76. Así, el enfoque de capacidades servirá de marco de evaluación de la calidad de la oferta educativa real, material y social, y también para constatar la calidad de protección que el Estado brinda a la vida, la dignidad, la autodeterminación y la realización de las potencialidades humanas de todos los colombianos.

75 Amartya Sen contribuye a la medición comparativa global de la calidad de vida, establece que las capacidades fallidas son fruto de la discriminación, sin embargo, no propone un umbral mínimo para cada una de las capacidades básicas, no elabora una lista de referencia ni asume el concepto de dignidad humana para fundamentarlas. Nussbaum contribuye a la construcción de la teoría de la justicia social básica, apoya en las nociones de dignidad, igualdad, liberalismo político y teoría de los derechos humanos (Nussbaum, 2012, pp. 38-39).

76 Nussbaum diferencia entre capacidades básicas, internas y combinadas (Nussbaum, 2000, pp. 42-44); condiciones sobre las cuales se concretan la dignidad, la igualdad y la libertad que, facilitan la práctica formativa y posibilitan problematizar la realidad (Nussbaum, 2000, pp. 66-67). Desde la econometría y el utilitarismo no se asegura la diferencialidad multiétnica y pluricultural de los beneficios del estado de bienestar que debe garantizar la educación incluyente. Con el PIB como medida de la calidad de vida no se dice nada sobre el beneficio diferenciado para las personas, pues el utilitarismo universaliza un tipo de vida estándar que no garantiza el trato digno a las personas; no se pregunta por las necesidades reales, sustanciales y relevantes de los individuos y los grupos humanos, se preocupa por constatar la satisfacción e insatisfacción. "Los individuos varían mucho en sus necesidades de recursos y en sus capacidades para convertir sus recursos en funcionamientos valiosos" (Nussbaum, 2000, pp. 97-119). 


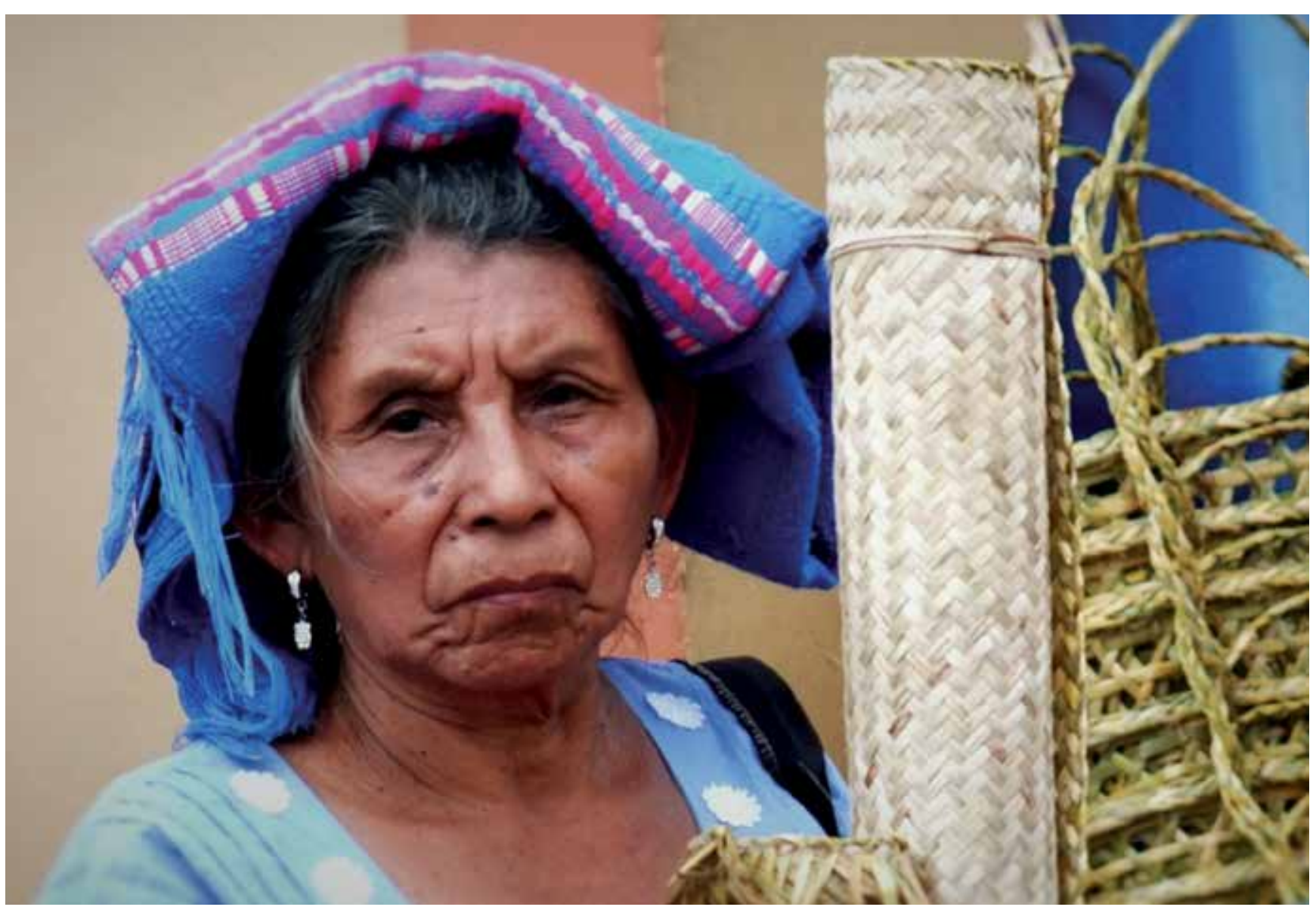

\subsubsection{Principios en los cuales se fundamen- ta el enfoque de capacidades}

Los principios de dignidad, igualdad y libertad fundamentan la capacidad humana para autodeterminarse, cooperar y hacerse cargo del propio proyecto de vida, asumiéndose como un "fin en sí mismo", que requiere de condiciones materiales y económicas para la plena realización; sin que ello sirva de excusa para que se le instrumentalice. La persona es "capacidad" y las capacidades son concreción de sus derechos ${ }^{77}$. Aunque, el concepto de dignidad

77 Además, de reconocer y valorar los aportes de Aristóteles, de Kant y de Marx para la propuesta de desarrollo humano, Nussbaum puntualiza en la contribución de los estoicos romanos, especialmente Séneca y Cicerón en cuanto a la concepción de dignidad e igualdad, afiliación y necesidad de los otros para la propia realización, capacidad para razonar éticamente, y hacerse responsable de los deberes que les competen a todos (Nussbaum, 2000, pp. 113-117, y Nussbaum, 2007, pp. 219, 273-280). Para determinar y sustentar su lista de capacidades humanas Nussbaum las enriquece, compara y diferencia de los aportes del liberalismo político de humana no es del todo claro y trasparente, y aunque amerite nuevos desarrollos, sobre todo desde la constatación de la fragilidad y vulnerabilidad humanas, tiene que ver con la posibilidad de "ser sí mismo", de "ser en sí" y "consigo mismo", sin ser instrumentalizado o convertido en medio para que otros logren sus propósitos, pues "cada persona es un fin en sí mismo", integral, respetable y distinto ${ }^{78}$.

John Rawls, que establece una lista sobre los "bienes primarios" (Nussbaum, 2000, p. 133). Las capacidades son "realidades que el hombre "es", y con las que puede "ser" y hacer; son posibilidades de realizar-se, y configurar su realización, y son impelencia, fuerzan al hombre a hacerse". Así, ultimidad, posibilidad e impelencia religan al hombre a la realidad, demandándole se realice consigo mismo, con los otros, y con la "realidad" de las cosas (Xavier Zubiri, 2004, p. 199).

78 El enfoque de capacidades humanas se fundamenta en la "dignidad" de las personas y en la necesidad de que sean protegidas sus libertades. Por el origen aristotélico de las capacidades en ellas se integran racionalidad y animalidad humanas, que posibilitan las "actividades vitales", dentro de las cuales la racionalidad es otro rasgo más de la persona. La temporalidad hace que los humanos necesiten afiliarse, depender estableciendo relaciones simétricas o asimétricas; por eso la dignidad no se puede definir 
Las capacidades son fuente de principios para una sociedad equitativa e incluyente, describen derechos civiles, políticos y sociales fundamentales. La base de las capacidades son los derechos universales, sometidos a permanente construcción, debate y concreción política. Se consideran elementos nodales de la lista de capacidades la libertad de expresión, la libertad de asociación, la libertad de conciencia, y el pluralismo de los estilos de vida ${ }^{79}$.

Garantizar la satisfacción de todas las necesidades básicas posibilita el ejercicio de las libertades sin interferencia ni condicionamientos que lo impidan, como una educación incapacitante o una economía rentista, que mantienen las asimetrías sociales o hacen invisibles las desigualdades y las violaciones a los derechos de las personas. Tanto el enfoque de capacidades como el de derechos humanos se apuntalan en la dignidad, la igualdad y el auto-respeto; en consecuencia se integran para reclamar, diferenciar, reconocer y protegerse con base en el "consenso entrecruzado" al que llegan. En síntesis, las personas son titulares de derechos de justicia en razón de lo cual les pertenecen por su condición humana.

de manera previa e independiente de la propia condición humana, se encuentra imbricada en las capacidades y estas la concretan en el funcionamiento digno (Nussbaum, 2007a, pp. 166-170; Nussbaum 2012, pp. 49-53).

79 Las características de las capacidades se construyen permanentemente con base en los principios universales de ethicidad, afiliación, dignidad humana y pluralidad de los estilos de vida. A diferencia del neoliberalismo utilitarista que trata al ser humano como un dato, como un medio dentro del cálculo social que remplaza bienes carentes por otros sobreabundantes, refuerzan las preferencias adaptativas y la dependencia de las personas (Nussbaum. 2007 , pp. $82-97$ y 279-294). Sobre las diversas concepciones de la naturaleza humana, la construcción de la identidad de las personas, y papel de la sociedad y la cultura, interaccionismo holístico (Steven Pinker, 2006, pp. 58-65). El hecho de que se recurra al término "capacidad", en tanto poder de realización que se lleva a cabo "reconociéndose sujeto en el encuentro con el otro"; se debe a que "las capacidades nos hacen presentes a nosotros mismos", por tanto "capaces" de reconocer a los "otros" como personas únicas a quienes de antemano y en "justicia" se les debe garantizar las condiciones indispensables de vida, consciencia y reflexión crítica. Más allá de los ritos del mercado y del intercambio de servicios, el otro me concierne en cuanto otro libre para actuar sin temor a no ser reconocido y sin sentir vergüenza de ejercer un derecho legítimo (Levinas, 2015, pp. 23-25, 40-41 y 123-132).

\subsubsection{Clasificación de las capacidades}

M. Nussbaum (2012) diferencia entre capacidades básicas, capacidades internas y capacidades combinadas, así: las básicas corresponden al equipamiento biopsicosocial de cada persona; las internalizadas se apropian por medio de la interacción socio-cultural, y las combinadas corresponden a aquellas capacidades que en un entorno específico concretan la respuesta de una capacidad básica ${ }^{80}$.

De otra parte, las capacidades centrales cubren el espectro de los derechos humanos de primera y segunda generación: políticos y civiles, económicos y sociales. Dichas capacidades son principios políticos que se exigen y garantizan en el ejercicio pleno de la ciudadanía y la civilidad $^{81}$.

80 Aunque Nussbaum (2000) centra su atención en las capacidades básicas en las cuales concretan derechos, se refiere a su funcionamiento como campo de elección, de opciones y de respeto en el que lleva a cabo la frónesis. Cuando el funcionamiento de una capacidad no se lleva a plena realización, entonces se infiere el nivel de daño de esta (pp. 130-139). La filosofa prefiere el lenguaje de las capacidades, más que el de los derechos humanos, dadas las dificultades que presenta el debate actual sobre el significado de estos, sobre la base racional, sensible y vital de los mismos, sobre su naturaleza política o pre-política (Nussbaum, 2000. p. 144). Precisamente en la cita 166 (Nussbaum, 2000. p. 145) clarifica por qué opta por las capacidades, pues concretan los derechos, los hace asequibles a todas las personas; superan la naturaleza nominal y especulativa de los derechos, y explicitan las condiciones en los derechos que deben vivencializarse (Nussbaum, 2000, pp. 146-147 y 167).

81 En consecuencia no hace falta recurrir al concepto de orden natural o de naturaleza para fundamentar las capacidades. Dicho concepto es equívoco: si con naturaleza se refieren a lo biológico, entonces a las tendencias innatas se les da tratamiento de cultura; si por "naturaleza" se entiende lo tradicional, lo que siempre ha sido así, entonces no hay cabida para el cambio histórico; si por el contrario lo natural se refiere a las mismas necesidades, estas pueden ser de otra manera, y si la ley natural tiene que ver con lo correcto, apropiado y moralmente aceptable, entonces se anula lo diverso e histórico normativo (Nussbaum, 2000, p. 334). Sin embargo, es evidente para algunos teólogos que el contenido asignado a la ley natural por la tradición tomista debe actualizarse para responder válidamente a la doctrina que fundamenta en ella los derechos humanos, y los principios de dignidad, igualdad y libertad. El debate está abierto, y a él contribuyen quienes consideran que la ley natural es un ordenamiento de los actos mediante la razón, según lo afirma Santo Tomás (St. I-Il, q.90 a.1), dado que los seres humanos dirigen sus acciones hacia un fin, y hacia la búsqueda de los bienes externos, corporales y espirituales movidos por la razón y la responsabilidad (St. I-II, 9. 91, a.2). De hecho la defensa de los derechos de los pueblos ancestrales de América, llamado el proceso de Salamanca, se efectúa con base en la doctrina de la ley natural, esta justifica el derecho de todo individuo a sus propiedades y a los bienes requeridos para la subsistencia. En sintonía con esta doctrina las capacidades humanas se consideran bienes. La ley natural tomista integra el valor liberal de la autonomía, la diversidad y la tolerancia, pero hace 
No es de extrañar que al tener sus raíces en fuentes aristotélicas o en lectores conspicuos del "filósofo", como Santo Tomás de Aquino, se llegue desde la perspectiva kantiana a conclusiones que coinciden con los fundamentos de las capacidades de desarrollo humano, a saber: la dignidad humana que concibe a la persona como fin en sí misma, que reconoce en la acción moral un rasgo propio de esta dignidad, y que es capaz de preguntarse por "las condiciones indispensables para que el ser humano actúe responsablemente". Dichas condiciones, bienes o capacidades que modulan el actuar moral tienen que ver con la "vida física, la protección de los bienes corporales y los derechos relacionados con la libertad", circunscritos en el ámbito del actuar humano. La dignidad humana es "condición inicial que hace posible ser y obrar de manera responsable por medio del desarrollo de los bienes éticos como: la vida, la amistad, la sexualidad, la reproducción, el juego, el conocimiento científico y la búsqueda de la verdad"82.

énfasis en la naturaleza social de la persona, en la pertenencia a una comunidad y en la importancia de la solidaridad y el bien común; mantiene el realismo moral, la visión integral del bien humano, el principio de igualdad de las personas, en consecuencia no da pie ni para el escepticismo ni para el relativismo (Tradición e innovación en la ley natural: una interpretación Tomista, de Lisa Sowie Lahill et al. Revista Concilium, (336), 2010, pp. 381-392. Naturaleza Humana y Ley Natural). En el artículo relacionado con "La ley Natural y la teología en contexto secular", de Eberhard Schockenhoff, en la cita 5 de la página 410 , se hace referencia al tratado De Veritate 21,1 en el cual Santo Tomás considera que: "el bien tiene carácter de un fin...aceptado por la razón práctica como una posibilidad de perfección ínsita en la condición humana". En consecuencia las capacidades del hombre se consideran como posibilidades dinámicas de desarrollo que están ínsitas en la naturaleza humana y que deben ser actualizadas por el actuar responsable del hombre, el artículo no establece diferencias entre hechos y valores. Por eso las capacidades aceptadas como posibilidades dinámicas de realización práctica integran valores morales y bienes prácticos (Ibídem, pp. 412-413. S.T. I.II, Prologus y l, 21, 1 ad, 2.). En perspectiva Kantiana la ética tomasiana del derecho natural se interroga por las condiciones insoslayables de posibilidad de actuación moral libre. (ibídem de qué autor?)

82 A conclusiones semejantes llega M. Nussbaum, pero sobre todo Eberhard Schockenhoff en Un enfoque Kantiano de la Teoría de la ley natural de Tomás de Aquino, Revista Concilium No 336 de 2010, pp. 407-416. Quien además destaca las capacidades cristianas de servicio, solidaridad, generosidad y vida comprometida con la justicia. Sobre el derecho natural se fundamenta la visión clásica griega de la ética y la política. Para Platón, Aristóteles y los estoicos la naturaleza era el parámetro para elaborar las leyes positivas, sobre todo si se tiene en cuenta que la razón guía el fin ético de la vida humana, por la estructura teleológica de los procesos naturales, porque la naturaleza del ser humano tiende a lo comunitario, y porque la capacidad de reflexionar $y$ tomar conciencia conduce a
Para dar respuesta a los detractores del enfoque de capacidades por su origen remoto en el iusnaturalismo, cabe aclarar que estas tienen que ver con la inmodificabilidad de algunos de sus principios jurídicos. Mientras que la realidad cambia y aparecen nuevas necesidades, el derecho natural se mantiene prisionero de lo abstracto y especulativo. En tanto que los derechos tienden a lo concreto, el derecho natural se perpetúa universalizando la dicotomía entre hechos y normas, sin atender a lo particular ${ }^{83}$. El proceso de diferenciación de la sociedad moderna y los marcos jurídicos que la interpretan separa la simbiosis tradicional entre moral y derecho, evidente en la "Lex" antigua. Las obligaciones morales dejan de coincidir con las obligaciones jurídicas, el derecho no se adapta a los "mandamientos" judíos. Aparecen nuevas necesidades políticas, socioculturales, éticas y económicas que fracturan el concepto monolítico de "naturaleza humana"84.

Las capacidades básicas tienen que ver con el equipamiento innato de las personas, aunque no son solo potencialidad, pues estas ya están condicionadas desde antes de nacer por el cuidado mismo de la madre y las costumbres culturales de la gestación, se relacionan con las facultades que los individuos traen al nacer y hacen posible el desarrollo y formación de los sujetos, y la riqueza de la diferencia, irrepetibilidad, y unicidad de las personas. Aunque las personas nacen con distintas habilidades e inteligencias a todas se les debe el mismo res-

la comprensión de la acción personal responsable (Schockenhoff, 2010, p. 421-422).

83 Pero, para algunos como Niklas Luhmann $(2005,218)$, citado por Jean Pierre Wils en: ¿Tiene futuro aun el pensar iusnaturalista? Revista Concilium, (336), 2010, pp. 449-450, el derecho natural pre-positivo continúa a través del derecho moderno positivo, por medio de la doctrina de los derechos humanos.

84 En el momento en el cual el concepto de naturaleza humana pierde su función conductora, éste se hace superfluo, dado que lo político, religioso, económico y ético se emancipan, hacen autónomos, desarrollan sus propios lenguajes, códigos deontológicos y normas regulación. Poco a poco el derecho natural se convirtió en retórica, su función de engranaje entre moral y derecho fue superado por el desarrollo autónomo de los derechos humanos, que fortalecen la capacidad de decisión individual, personal, histórica, en un contexto sociocultural concreto; modificándolos y ampliándolos en cuanto lo exija la dignidad, el respeto, la igualdad y la libertad humana (Revista Concilium, (336), 2010, pp. 451-459). 
peto, pero las sociedades equitativas tratan de aportarles más a quienes están en mayor desventaja para elegir y actuar ${ }^{85}$.

Las capacidades internas, en palabras de Nussbaum (2012), son los rasgos y aptitudes entrenados y desarrollados en contextos específicos de socialización: familiar y colectivo, institucional y educativo que posibilitan el aprendizaje de diversas habilidades. Cuando el sistema educativo es de buena calidad fertiliza y potencia, a la manera de suelo fértil, todas las capacidades de las personas; pero cuando la educación es de mala calidad e incapacitante, reduce la autonomía de las personas, y las oportunidades de libertad y de realización humanas (Nussbaum, 2012, p. 41).

El desarrollo de las capacidades, habilidades y aptitudes humanistas son prioridad en la gestión de la formación integral. Por eso, al preguntarse ¿cómo debería ser un buen ciudadano?, y ¿cómo se debería formar?, la filósofa plantea con base en la tradición humanística de Occidente ciertas características para el "Cultivo de la Humanidad", indispensables al momento de formar ciudadanos del mundo. Así mismo, en el texto Sin fines de lucro (2011), Nussbaum hace evidente el papel que juegan las humanidades en la consolidación de la democracia, y el riesgo de que el afán competitivo y técnico financiero haga que ciertas capacidades vitales para la convivencia civilizada se pierdan por la premura de hacer rentable el mercado global, el estado de bienestar y la sociedad de la satisfacción.

Sin que se desconozca el valor de las ciencias exactas en la formación universitaria, dada

85 Insiste la filósofa en que las capacidades básicas no pueden dar pie al trato discriminatorio o meritocrático, y en que es al sistema educativo a quien le compete determinar cuáles son las capacidades internas que le interesa priorizar para llevar a la madurez, la convivencia justa y a la civilidad (Nussbaum, 2012, pp. 40-48). El contractualismo de John Rawls y las capacidades de Nussbaum comparten algunos puntos, pues parten de que los seres humanos son iguales, consideran que la igualdad política necesita de apoyos de parte del Estado, concuerdan en la importancia del consenso entrecruzado para garantizar la pluralidad, ambos enfoques proponen una estructura teórica en función de juicios ponderados que buscan consistencia y enfatizan en la dignidad y el respeto por las personas (Nussbaum, 2007, pp. 168-180). la urgencia de restaurar la convivencia pacífica, también debería propenderse por el pensamiento crítico, la imaginación comprensiva y la compasión empática ${ }^{86}$, sobre todo en el caso de las víctimas del conflicto armado. Porque, de no hacerlo, los intereses económicos y las políticas rentistas impondrían modificaciones en los currículos, en los enfoques pedagógicos y en el sostenimiento económico del sistema educativo, sobre todo como preparación para el trabajo en la sociedad eficaz. En síntesis, se exige estar atentos para que la integralidad de la educación no sea menoscabada, se garantice la pluralidad democrática y la participación en los consensos que aseguren el trato digno, respetuoso e igualitario para todos ${ }^{87}$.

De la tradición socrática, consolidada por los estoicos romanos, se recoge el principio de la "vida examinada" o del examen crítico y reflexivo que somete a la "razón deliberante" los miedos, las creencias, las tradiciones y las costumbres. La construcción de la personalidad por medio de la razón que indaga por la verdad, modela las motivaciones, afina la lógica, la argumentación, los presupuestos para elegir, sopesa los motivos para actuar, ayuda a controlar pasiones y emociones, y hace a las personas responsables de sus decisiones, además se enriquece cuando supera la connaturalización de lo cotidiano por medio del examen razonable de las motivaciones. Lo que implica para el sujeto conocer su historia de vida, atender a las necesidades reales, enfrentarse con modos diversos de existencia, valorar lo diferente, reconocer lo común, centrarse en la

86 El análisis lógico, la imaginación comprehensiva, la reflexión crítica también son propias de las ciencias exactas y científicas de las que adolece la educación superior (Nussbaum, 2011, pp. 25-28).

87 A juicio de la filósofa es indispensable asegurar el ejercicio democrático formando ciudadanos reflexivos, críticos, capaces de pensar idóneamente acerca de las múltiples interdependencias de la comunidad humana actual. De la misma manera que se necesitan ciudadanos capaces de impulsar la economía y la empresa, se requiere que estos mismos ciudadanos se nutran de sentido crítico, creatividad, imaginación comprensiva, y civilidad. En consecuencia el acceso a la educación de calidad que asegure la formación de estos ciudadanos es un asunto que tiene que ver con la convivencia pacífica, el posconflicto y la estabilidad democrática del país (Nussbaum, 2011, pp. 28-31). 
vida de manera sensible, y aprovechar los libros sin sacralizarlos ${ }^{88}$.

La globalización, con sus efectos negativos y positivos, ha acelerado el reconocimiento intercultural, la visión cosmopolita, los consensos entrecruzados, y la concepción de ciudadanía universal. Sin embargo, aún nos atemoriza indagar por cómo los valores culturales, la ética, las costumbres y las tradiciones de otras sociedades relativizan, iluminan o amplían los horizontes de comprensión de la nuestra. Reconocernos como parte de la comunidad humana universal contribuye a mirar nuestros problemas desde otras perspectivas, tomando distancia reflexiva de los mismos e identificando las desigualdades en sujetos concretos. El currículo multicultural se fundamenta en el conocimiento profundo de nuestras propias culturas y pueblos ${ }^{89}$.

La tendencia a invisibilizar a los otros, a desconocer sus circunstancias de vida o a establecer estereotipos de personas y culturas, dificulta reconocernos, y ser reconocidos como "otros". La carencia de imaginación narrativa y de comprensión sensible, también nos impide acercarnos a los motivos de vida y sufrimiento de otras personas. El hecho de reflexionar sobre los propios errores de percepción, y sobre las tácticas para invisibilizar a los demás, contribuye a que identifiquemos las circunstancias que hacen imposible que las personas actúen, decidan, deseen y se comprometan con ellas

88 Razonar por sí mismo, sopesar los argumentos, diferenciarlos, validarlos, someterlos al juicio de la realidad, y desenmascarar sus prejuicios, son aptitudes propias de una vida examinada que da lugar a visiones diferentes. Desenmascarar los argumentos de autoridad y los intereses que el poder quiere hacer aparecer como legítimos, o la ingenuidad da por verdaderos y objetivos, hacen parte de los propósitos de una "vida examinada" (Nussbaum, 2005, pp. 29-64). Los seres humanos somos esclavos del "narcisismo", de la jerarquización de las relaciones humanas, y de las ganas de dominar a los más débiles, mientras que frente a quienes detentan más poder nos mostramos serviles y pasivos. La agresividad narcisista irrespeta la dignidad y la igualdad de las personas. Pero, ¿qué aptitudes del ser humano se oponen a la reciprocidad y a la colaboración? (Nussbaum, 2011).

89 El aprendizaje de idiomas, el conocimiento de la geografía y las costumbres de otros pueblos, lo mismo que el intercambio cultural, docente e investigativo se orientan a la construcción de ciudadanos del mundo (Nussbaum, 2005, pp. 75-96). mismas. La imaginación sensible ayuda a interiorizar y a reconocer miedos, privilegios, convenciones, costumbres, aprehensiones, expectativas y maneras arraigadas de hacer insignificantes a las personas. Ponerse en el lugar del otro contribuye a identificar las tensiones entre esperanza y miedo, felicidad y aflicción, sabiduría y temeridad ${ }^{90}$.

Confrontar los mundos de representación cultural occidental con los modos de representación, narración y ética no occidentales, ayuda a valorar la contribución de otras tradiciones al cultivo de la humanidad: emergen nuevos estilos de vida, aparecen otros interrogantes, surgen nuevos desafíos, y al escudriñar se encuentran sentidos de historia que debemos cuidarnos de distorsionar, tergiversar, instrumentalizar y utilizar, restándoles originalidad. Todas las culturas, también la nuestra, se reconfiguran, combinan, desfiguran y configuran. Sin embargo, paradójicamente las culturas dominantes eliminan lo "extraño", original y propio porque lo consideran poco evolucionado ${ }^{91} \mathrm{o}$ amenazante.

En este sentido, considera Nussbaum (2011) que los seres humanos tendemos a hacer daño a otros con tal de que la autoridad lo apruebe $o$

90 La literatura desempeña un papel preponderante en la formación humanística, pues el contacto con la imaginación literaria desarrolla compasión, contribuye al cuestionamiento de lo inmodificable, a la crítica de los propios valores, y a obrar superando los inamovibles (Nussbaum, 2005, pp. 117-134). La conciencia de los propios miedos, demonios y fantasmas, nos pone alerta para no proyectarlos en los demás, estos se contrarrestan por medio de la comprensión imaginativa, la empatía creativa y los sentimientos compasivos. La literatura, el teatro y el arte median la comprensión de otros, también de los que no se conocen, posibilitan la catarsis frente a lo que nos avergüenza o nos repugna, sobre todo si se tiene en cuenta que: "el narcisismo, la indefensión, la impotencia, la vergüenza, la repugnancia, y la comprensión son el núcleo para formar en la convivencia pacífica" (Nussbaum, 2011, pp. 61-68). Pero, las capacidades no se resuelven solo en términos de conciencia, saber y poder, también dan paso el reconocimiento de las impotencias, los errores y las torpezas; en la medida en la cual posibilitan fundar las relaciones con los otros en la diferencialidad y en la pluralidad, pues el saber no nos hace dueños del mundo; por el contrario nos posibilita el encuentro con lo que hay detrás de nosotros mismos, participar en la "razón del propio ser", en la comprensión y engendramiento del mundo en su conjunto (Levinas, 2015, pp. 132-137).

91 El cultivo de la humanidad en la educación superior demanda indagar en otras tradiciones culturales distintas a la occidental, para apreciar la originalidad de estas y su aporte en la construcción de civilidad (Nussbaum, M., 2005, pp. 149-167). 
podamos sacar réditos de aceptación; contradecimos las evidencias reales con el propósito de sumarnos al coro de quienes confirman lo mismo; tendemos al servilismo y a la sumisión, aunque haya que perseguir a otros, sobre todo para congeniar con el grupo; y aprovechamos que la responsabilidad recae sobre otros para actuar de manera irresponsable; aún más, modificamos el comportamiento cuando hay ventajas de por medio, y adoptamos "roles" indecentes e irrespetuosos para quedar bien con la galería ${ }^{92}$ aunque haya que perseguir a otros.

En contraste con lo anterior, en cuanto a la formación de los sentimientos morales, la universidad debería capacitar en la imaginación comprensiva para ver la realidad desde la perspectiva de otros; a fin de que no sea la vergüenza, el asco o la repugnancia de nuestra vulnerabilidad e indefensión lo que proyectemos. También, la universidad debería promover la capacidad de disentir y oponerse a la irreflexión y sacralización del tradicionalismo, el orden y las costumbres, detrás de los cuales se enmascara el poder y se perpetúan los privilegios de lo "normal"; a su vez, debería promover la reflexión crítica y el estudio histórico de las culturas minoritarias con el propósito de superar los estereotipos, sesgos de clase o simplificación de la pluralidad de opciones de vida, pero ante todo la universidad debería partir de la realidad de los contextos de vida de los estudiantes, de sus expectativas de vida y de realización ${ }^{93}$.

92 Sobre todo el anonimato y el desplazamiento de la responsabilidad en otras personas favorece la actuación irresponsable de los seres humanos (Nussbaum, 2011, pp. 68-71).

93 El estudio pormenorizado del déficit de comprensión ética lo aborda la filósofa, en contexto de la educación cuando analiza los "sentimientos morales" (Nussbaum, 2011, pp. 64-67). La pedagogía como proyecto ético en la construcción de la persona, y como respuesta a la vida, orientada al compromiso emancipatorio, constituye el aporte de Fray J. de J. Sedano en perspectiva personalizadora de corte Aristotélico. Afirma Fray Sedano que de lo que se trata es de "dar mi propia respuesta" con la que me juego mi realización personal, pues "no puedo realizarme sin responsabilizarme; no puedo responsabilizarme sin personalizarme; no puedo personalizarme sin definirme; no puedo definirme sin auto-determinarme; no puedo auto determinarme sin comprometerme, y no puedo comprometerme sin decidirme" (2012). En relación con la propuesta de "Desarrollo de las capacidades humanas", de Sedano, sería el desarrollo de la "capacidad de hacerse cargo de sí mismo, de la realidad de los otros, y de la realidad histórico con-
En cuanto a capacidades complejas o de religazón, incluidas en las capacidades internas propuestas por Nussbaum, cabe agregar a los "aprendizajes básicos", definidos por Edgar Morin ${ }^{94}$ : (1) ser capaces de "conocer lo que es conocer y cómo se conoce", para que conociendo la naturaleza del mismo, las personas reconozcan, eviten y superen "los errores e ilusiones" que parasitan e impiden la lucidez humana; (2) ser capaces de "aprehender los objetos de conocimiento en sus contextos circunscritos", ubicando los datos y la información en la complejidad de sus múltiples relaciones; (3) ser capaces de aprehender religando lo que significa el ser humano "físico, biológico, síquico, cultural, social e histórico", con el propósito de superar la fragmentación curricular, contribuir a superar los enfoques reduccionistas, y posibilitar el reconocimiento de los otros seres humanos; (4) ser capaces de asumir la identidad terrenal; (5) ser capaces de identificar y responder adecuadamente a las múltiples incertidumbres, aprovechando la información disponible para asumir lo inesperado; (6) ser capaces de trasformar el ethos socio-cultural por medio de la imaginación comprensiva, indispensable para la reciprocidad, el respeto y la interdependencia mutua; y (7) ser capaces de actuar de acuerdo con la ética biopsicosocial, que alerta sobre las implicaciones que las acciones humanas tienen en nosotros, en la sociedad y en la especie.

En cuanto a "ser capaces de conocer lo que es conocer y cómo se conoce", Morin (2000, pp. 24-25) insiste en que es necesario aprehender a que hay "condiciones bio-antropológicas, socio-culturales y noológicas" de cuyo nudo surgen problemas que ameritan la atención de quienes investigan y construyen el conocimiento. De igual manera, capacitarse para desenmascarar las propias mentiras, ilusiones, errores en torno al conocimiento, tanto como las mentiras, intereses y manipulaciones que rondan alrededor del conocimiento, nos hace

textual" de manera autónoma, libre y comprometida.

94 Citas 34 y 51 del presente artículo, en las cuales se recoge la propuesta de Edgar Morin (2000). Acerca de cómo las ciencias de la incertidumbre surgen y se posicionan en el debate epistémico e investigativo, así como en los horizontes de complejidad y comprensión de los hechos sociales Pablo González y Marcos Roitman (2006, pp. 261-280). 


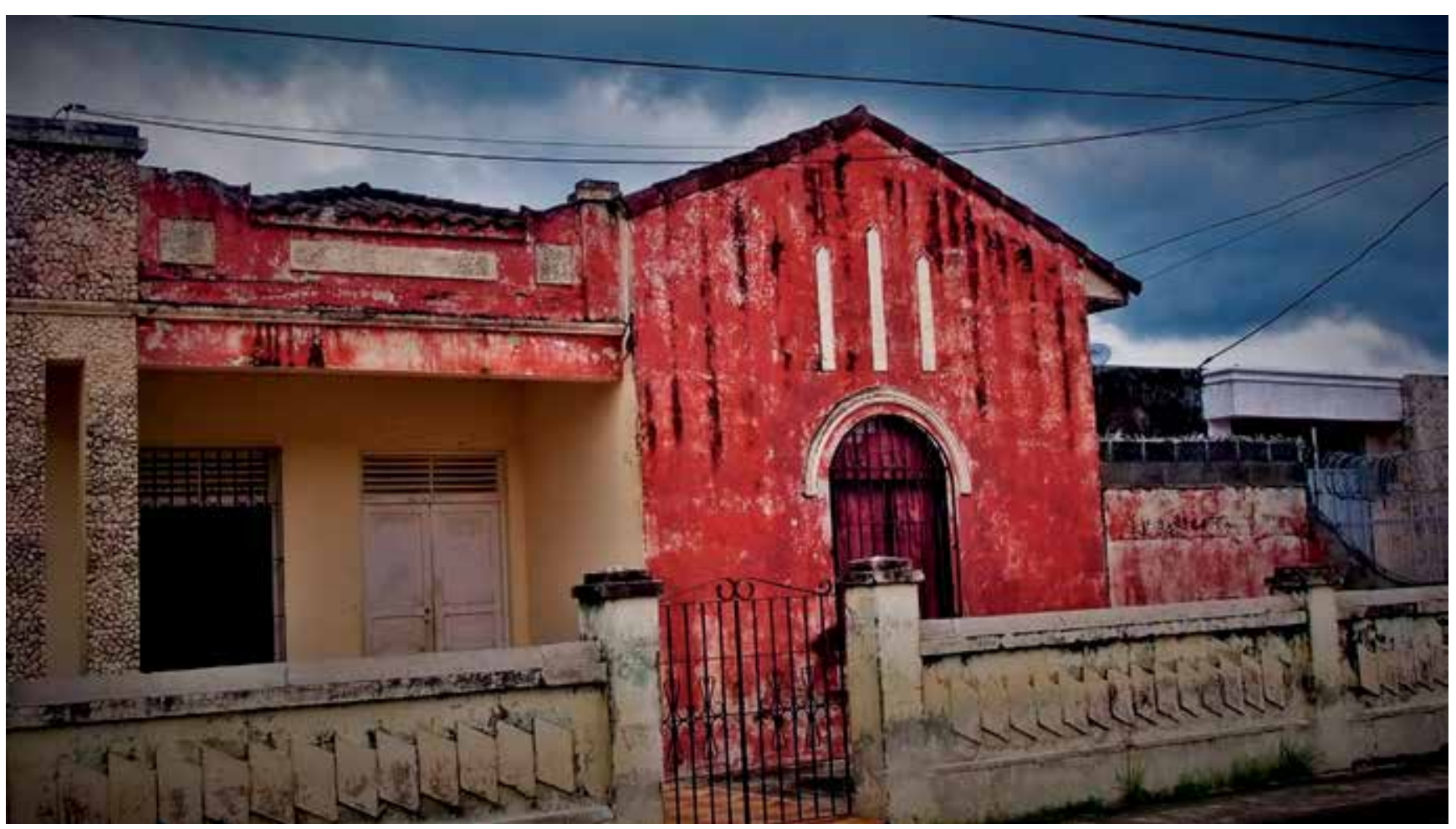

conscientes de la violencia que esto causa cuando no se tiene presente que estamos abocados permanentemente al error y a la ilusión.

Con relación al conocimiento pertinente, se requieren personas capaces de acceder a la información relevante y adecuada, de manera selectiva, articulada y organizada; a fin de que desde la multidimensionalidad y globalidad, se contribuya a las soluciones locales. Además, se carece de personas capaces de unir, transversalizar e integrar saberes, que garanticen la perspectiva contextual, global, multidisciplinar y compleja. En consecuencia, personas capaces de superar los modelos epistémicos tradicionales, disyuntivos, dicotómicos y superespecializados que se alimentan de falsas racionalidades: abstractas y unidimensionales (Morin, 2000, pp. 27-34).

La educación centrada en la condición humana debe ocuparse de capacitar para: apreciar la pluralidad de las culturas, al mismo tiempo que todo lo común que nos une como humanos, situados en el mismo mundo, religados con el universo, la tierra y la vida en todas sus manifestaciones empíricas y culturales; para asumir la complejidad de lo humano expresado en las triadas cerebro-espíritu-cultura, religada con la de razón-afecto-impulso, e integrada al bucle de individuo-sociedad-especie. En consecuencia, ser capaz de aceptar la condición humana implica hacer consciente la dialogicidad permanente entre sapiens-demens que dinamiza el potencial creador e innovativo de los seres humanos (Morin, 2000, pp. 35-45).

El que se urja a salvar, tanto la unidad, como la diversidad humana, implica ser capaces de reconocer la unidad en la diversidad; los lazos consustanciales que nos unen con todas las especies vivientes en la tierra y en el universo; la solidaridad que nos hermana con quienes habitamos la tierra, y que nos permite superar el narcisismo y la obsesión consumista. En consecuencia, la toma de consciencia antropológica, ecológica, cívica y espiritual nos posibilita ser capaces de valorar y apropiarnos de los aportes de la "contra-corriente ecológica", de quienes 
se resisten a la instrumentalización, mercantilización y cuantificación de la vida (Morin, 2000, pp. 47-58).

En el camino de explicación de lo humano, las personas deben ser capaces de acoplarse, crecer y enfrentar las incertidumbres de lo real, del conocimiento y de la acción, según los vínculos cerebro-mente para la construcción y reconstrucción del conocimiento, para la indagación de las verdades y los nuevos supuestos lógicos, para la amenaza permanente del racionalismo y la necesidad de racionalidad reflexiva y la toma de consciencia autocrítica frente a todo lo que experimentamos como fruto del inconsciente (Morin, 2000, pp. 59-68).

Frente a la carencia de sensibilidad y a las exigencias de la interdependencia humana, se debe capacitar para la imaginación comprensiva y la ética de género humano (Morin, 2000, pp. 69-86).

Las "capacidades internas" actuadas en condiciones sociales, políticas, económicas, culturales específicas se consideran como "capacidades combinadas", en la medida en la cual se concretan en modos de funcionamiento: elección, decisión, actuación, desempeño y compromiso (Nussbaum, 2012, pp. 44-45). Para cada persona son diferentes, dado que los contextos y el desarrollo de las capacidades internalizadas particularizan la concreción de la capacidad que le pertenece ${ }^{95}$. El funcionamiento de las capacidades combinadas tiene que ver con las posibilidades de elección, la escogencia entre varias alternativas, y sobre todo con la acción correspondiente. Las situaciones humanas por restrictivas que sean tienen al menos otra opción. Sin embargo, hay que exigirse elegir y decidirse, descubrir y desentrañar ${ }^{96}$, actuar en condiciones

95 Las capacidades se tienen para funcionar, es decir, para concretar los derechos en circunstancias históricas específicas (Nussbaum, 2007, pp. 177 y 185 ).

96 Al escribir Sobre la educación en mundo líquido, Zygmunt Bauman (2013, pp. 33-35) confía en que las nuevas generaciones se enfrentarán a los desafíos, y aprovecharán las oportunidades que les depare el "destino" en forma satisfactoria y esperanzadora. de incertidumbre, sin dejarse imponer modos compensatorios de satisfacción tecno-nihilista97.

\subsection{Las capacidades centrales ${ }^{98}$}

Las capacidades centrales son los mínimos exigibles de condiciones y oportunidades que un ser humano requiere para ser sí mismo según la dignidad y el respeto que merece como igual a todo otro ser humano, es decir: "lo mínimo que se necesita para que una vida esté a la altura de una vida humana digna". El umbral mínimo, según la justicia social y distributiva, se exige para que el trato sea digno, y sirva de punto de referencia en la superación de las inequidades ${ }^{99}$. Las capacidades centrales son diez, cuya naturaleza diferenciada e importan-

97 Así mismo, considera Bauman (2013, pp. 38-39) que las personas deben formarse haciéndose conscientes de los mecanismos compensatorios que utiliza el mercado para sacarle ventajas en beneficio propio hasta los problemas humanos. Pues, la cultura de "casino" de la cual habla George Steiner, se nos impone por seducción rellenando de información todo espacio de tiempo que aún no esté cubierto, rompiendo el vínculo narrativo con el pasado y con la memoria que identifica, profundiza y perdura (Bauman, 2013, pp. 41-48). Frente a la alternativa deficitaria de vida que ofrece el mercado laboral, protector de privilegiados, los jóvenes profesionales requieren tener en claro que para "funcionar" con cierta posibilidad de sobre-aguar se deben formar en las "capacidades de inventiva, conocimiento, imaginación creadora, habilidad de pensamiento alternativo y valentía para diferenciarse", con talento, agudeza, sentido crítico, y defensa de la equidad que ponga freno a la nueva sociedad de clase "globalizada, rentista y excluyente" (Bauman, 2013, pp. $49-61$ y 75-83).

98 La lista es fruto de un consenso traslapado, transcultural y comparativo, concertado al margen de los intereses políticos particulares, de presupuestos metafísicos religiosos y de sesgos éticos individualistas; que asumida desde distintas áreas se constituye en centro moral y político en el cual convergen múltiples perspectivas de realizabilidad humana, y continúa abierta, construyéndose y en permanente reflexión. Las característica de lista básica se mantiene desde Las Mujeres y el desarrollo humano (2000, pp.120-123), se fortalece con los aportes continuados en artículos y libros, y se explicita y amplía en Crear capacidades (2012). De manera recurrente Nussbaum insiste en que su propuesta prioriza las capacidades por encima del funcionamiento de estas; argumenta la diferencialidad e igualdad en importancia de las mismas, la imposibilidad de reducirlas o intercambiarlas entre sí. Puntualiza en que se soportan en la razón práctica, en la filiación, en la comunicabilidad y en la exigencia de llevarse hasta la plenitud (Nussbaum, 2000, pp. 114-125).

99 Se propone el umbral para que las personas se sitúen por encima de éste dada la dignidad y el respeto que merecen los seres humanos (Nussbaum, 2012, pp. 53-61). A juicio de la filósofa la fuente occidental más antigua sobre capacidades es Sócrates, pero como éste no efectúa una propuesta política sistematizada, entonces es Aristóteles quien lo hace complementándolo con la reflexión ética. Para el estagirita los que planean lo público se deben preocupar por las necesidades reales de las personas, más allá de las satisfacciones económicas, de aquí que se preocupe por la educación de los jóvenes (Nussbaum, 2012, pp. 151-157). 
cia intrínseca las hace irreductibles las unas a las otras, y por el daño que puede causar su vulneración y entorpecimiento, deben ser protegidas jurídicamente para garantizar que se puedan llevar a cabo ${ }^{100}$. Las capacidades propuestas son producto del consenso entrecruzado que se fundamenta en la dignidad e igualdad de las personas, en el ejercicio de la razón práctica, y en la salvaguarda de los derechos de todos y todas por medio de leyes que les protejan de cualquier daño ${ }^{101}$.

Como se afirmó con anterioridad, el listado de capacidades centrales parte de la idea de realización humana ética, afiliada, justa y razonable, de la concepción de la persona como un animal político que goza de derechos inherentes a su naturaleza, y no de verdades autoevidentes y metafísicamente estipuladas. Pero, ¿qué papel desempeña la noción de ser humano, de dignidad humana y de desarrollo por capacidades en la actualización del proyecto

100 El choque entre competencias conduce a dilemas trágicos, solo comprensibles dentro de la historia de vida de las personas, a veces por factores externos que condicionan y reducen el ejercicio pleno de la libertad (Nussbaum, 2012, pp. 56, 63-64).

101 La experiencia, la intención, la búsqueda de resultados y los juicios intervienen en la elaboración de la lista de capacidades centrales fundamentadas en la dignidad, el respeto y la igualdad de las personas, a quienes se les debe asegurar un umbral mínimo de requisitos de justicia civil, política, y socio-económica. A diferencia de John Rawls, para quien la justicia como equidad es procedimental, y debe partir del aseguramiento de los"bienes primarios", la elaborada por Nussbaum sirve para evaluar la calidad de vida y la adaptación a los cambios contextuales de las personas (Nussbaum, 2007, pp. 171-185). Los aportes de Michael Walter, (Nación y Mundo, 1996) a los cuales se refiere Jean Pierre Wils en: "¿Tiene futuro aún el pensar iusnaturalista? (Revista Concilium, (336), 2010, pp. 449-462) esclarecen el tipo de "universalismo reiterativo" del cual tratan las capacidades centrales; el modo como estas surgen, se reconocen y validan en un contexto específico de razón práctica, y retornan como respuesta a lo individual, sin que lo oculten, asimilen u homogenicen. Al contrario de lo que sucede con el "universalismo omnicomprensivo" y totalitario que subordina lo particular a lo universal para luego eliminarlo, basándose en el carácter abstracto, descontextualizado e independiente de su universalismo. El modo de evitar el reduccionismo especulativo, universalista y totalitario es abordar las "capacidades desde la interpretación moral", tanto desde el énfasis "tenue" que nos vincula en lo común universal con otras personas con quienes compartimos lo humano, como desde lo máximo, "denso, específico y vital", que antecede a lo "tenue y mínimo exigible", pues es la obstrucción del ejercicio de la capacidad, la que ayuda a identificar el derecho menoscabado, y en consecuencia a actuar para modificar el contexto que impide el ejercicio libre de la capacidad. En situaciones nuevas de conflicto y tensión el significado y la comprensión de las capacidades deben reconstruirse. educativo de la universidad? ¿Qué implica para el modelo de dirección, administración, finanzas, investigación, proyección social y bienestar la actualización de la gestión centrándola en el enfoque de desarrollo humano integral por capacidades? ${ }^{102}$

\subsubsection{Listado y descripción de las capacidades centrales}

El siguiente listado de capacidades de desarrollo humano, además de concretar los derechos de las personas, especifican en posibilidades de acción los conceptos de dignidad, respeto e igualdad, al considerar que las capacidades son libertades que requieren ser actuadas $^{103}$. Estas se promulgan del individuo en tanto "fin en sí mismo": Vida, en cuanto agenciamiento de la propia existencia, contando con los medios indispensables para lograrlo de modo expansivo, gratificante y seguro; salud física, en cuanto poder para conservar una buena salud, también la reproductiva, con base en una alimentación sana, y en el disfrute de un lugar protegido para habitar; integralidad física, en tanto facultad para la libre movilidad, salvaguardado de cualquier riesgo de agresión física, mental y sexual sin sentirse discriminado; cultivo de los sentidos de pensamiento e imaginación, como poder para aprovechar la creatividad y razonabilidad inventiva en lo plenamente humano, en la generación de la ciencia, el arte y la técnica sin condicionamientos políticos o impedimentos ideológicos; emociones, poder para vincularse afectivamente, expresar, rechazar, mantener y fortalecer la asociatividad y el desarrollo emocional; razón práctica, para forjar

102 El listado propuesta debe ser sometido al debate crítico, a la confrontación con el contexto y al análisis entrecruzado, de modo que lo acordado no sea solo fruto de la conveniencia interesada en la defensa de lo propio, sino porque la capacidad humana beneficia a todos (Nussbaum, 2007, pp. 186-218).

103 El listado que se comenta ha sido trabajado en forma permanente por la filósofa, quien sugiere que se someta a validación en todos los contextos en que se utilice, también en las instituciones de educación superior. La versión más actual es la de Crear capacidades (Nussbaum, 2012, pp. 53-55). En la reciente publicación Emociones políticas. ¿por qué el amor es importante para la justicia? (2014, pp. 500-501) Nussbaum recoge el listado de capacidades propuesta desde Las fronteras de la justicia (2007, pp. 88-89). 
el sentido de la vida según el marco de valores propios que le resulte significativo para orientarla; afiliación, para interrelacionarse o establecer vínculos asociativos con entera libertad, sin riesgo a ser humillado o a experimentar vergüenza; otras especies, facultad para el aprecio, disfrute, protección y vínculo con el medio ambiente; y"control político sobre el propio entorno político y material" 104 , para ejercer los derechos civiles, sociales y políticos, así como los derechos económicos y empresariales.

Aunque el anterior compendio de capacidades se acepte por muchos colectivos y organizaciones, lo aconsejable es que en cada caso se debata, adecúe y resignifique. El análisis comparativo del mismo amplía los niveles de comprensión y concreción para los interesados.

\section{3 ¿Capacidades y/o competencias?}

Aunque el propósito de este artículo no es sumarse al debate sobre lo adecuado e inadecuado del enfoque de competencias y capacidades para trazar procesos de crecimiento formativo o constatar logros de aprendizaje, sin embargo, no lo puede soslayar, al menos en lo atinente a los aspectos que le incumben en relación con el enfoque de desarrollo humano integral, el marco socio humanístico de la presente propuesta, como en relación con la alternativa pedagógica del mismo ${ }^{105}$; dado que

104 Los contenidos y aptitudes relacionadas con cada una de las capacidades centrales se encuentran descritos en varios listados que en el transcurso de los años de reflexión ha ido validando Nussbaum, pero es en el texto Crear capacidades, en el cual de manera concreta ahonda y profundiza en estas (2012, pp. 53-55).

105 Para los interesados en las raíces filosóficas de las capacidades y las competencias, estas se remontan hasta Aristóteles, como se anotó con anterioridad en los aportes de M. Nussbaum (2012); otros, entre ellos N. Chomsky (1965), en la Gramática generativa, las vinculan con René Descartes y su concepto de inteligencia, que más adelante retoma la psicología. Sobre todo, por el propósito de este artículo llama la atención la traducción que hacen de dicho término por "responsabilidad", haciendo derivar la "competencia" del latín cum-petere, "pertenecer a" o "incumbe a". La propuesta de usar las competencias para valorar el "dominio comunicacional", se fortaleció en el sistema educativo colombiano apoyándose en los aportes de Chomsky. Entre los autores que usan indistintamente capacidades y competencias, sobresale David McCleIlan (1973), pues para él son sinónimas. Howard Gardner (1980) encuentra que las competencias se relacionan con las funciones cerebrales de cierto tipo de inteligencia. Se puede seguir la ruta de desarrollo de este concepto en Fidel. A. Cárdenas (2003, 24-25). estos apuntan a la formación metacognitiva humana integral ${ }^{106}$.

Para los detractores del concepto "competencia" en el contexto de lo educativo, por su origen, uso instrumentalista y orientación mercantilista, este es espurio, neo-liberal y sospechoso. En cambio para sus adeptos, el concepto de competencias se refiere a la formación centrada en los sujetos, integral y contextualizada; además, lo encuentran adecuado para superar la propuesta pedagógica tradicional, academicista y fragmentada.

Aún más, dentro de las corrientes educativas que utilizan el enfoque formativo por competencias se encuentran diversos matices, desde quienes lo vinculan con la formación integral humana, con el desempeño en contextos de práctica, con la regulación estratégica y trasformadora, hasta quienes lo relacionan con el uso óptimo

\footnotetext{
"Aspectos Teóricos y prácticos en el desarrollo de competencias como objetivo educativo formal", en Revista Internacional Magisterio, (1). Coincide con la propuesta nuestra de "desarrollo humano" en perspectiva ética, crítica, interrelacional y contextual, aún en los listadas de capacidades básicas propuestos M. Nussbaum (2012) la que establece José A. Duran (2003: 16-18). “Educación y desarrollo humano. Un marco de Acción para las competencias". En: Revista Internacional Magisterio, (junio-julio), (3). Además de recabar en las fuentes conceptuales remotas y próximas de las competencias, y de coincidir en el uso que hace N. Chomsky al vincular la lingüística con la psicología, subraya el aspecto novedoso del uso que se hace oficialmente como parámetros para constatar la calidad de la educación, y el cumplimiento de las recomendaciones de los organismos internacionales que orientan el desarrollo económico mundial, se puede consultar la crítica de Guillermo Bustamante Z. (2002, 11-35). El concepto de competencias II. La moda de las competencias. Otro de los analistas, Sergio De Zubiría (2002, 37-61). El concepto de competencias II. La mala pedagogía se hace con buenas intenciones; nos recuerda que las competencias no son lo único ni lo último, y que hay aspectos de la vida humana que no son evaluables por medio de competencias, que corresponden a lo genuino a lo diferencial de cada sujeto, y de cada instante, por consiguiente no cabrían en modelos predeterminados de valoración, Con relación a las definiciones de competencias más recurrentes nos invita a profundizar en los problemas más acuciantes relacionados con las competencias, a saber: ¿qué es idoneidad en el campo de las competencias?, ¿cómo se reconoce un contexto de actuación?, ¿qué prima el tiempo o el contexto?. Pero, ¿Sabemos qué hablamos cuando usamos el término competencias?, a clarificar los significados contribuye el artículo de María Paula Bacarat y Nora Ana Graziano (2002, 63-89). El concepto de competencias II. Colombia, Bogotá. Sociedad Colombiana de Pedagogía.

106 La propuesta de la Unesco, esbozada como aprender a aprender a ser, conocer, hacer, convivir y trascender de manera consciente, y elaborada por Jacques Delors (1996), La Educación encierra un tesoro, mira al desarrollo de la capacidad de "hacerse cargo de", al crecer y hacer responsables.
} 
de los recursos y mediaciones profesionales. Lo que pone en evidencia la polisemia del término y la necesidad de precisar desde el principio el significado que el presente artículo le otorga, sobre todo en relación con los conceptos de "capacidades", habilidades, aptitudes y destrezas.

El uso experto de quienes en el campo de la educación recurren al concepto de competencia, lo relacionan también con el saber-hacery el saber-actuar de manera consciente y transformadora; dan por hecho que quien sabe-obrar de esta manera sabe de qué se trata y goza del conocimiento suficiente e indispensable para el "saber-cómo hacerse cargo de", es decir, para responsabilizarse de la acción ${ }^{107}$.

En el presente artículo siempre que se utilice el concepto de capacidad es para referirse al "ser y crecer como persona", y el término competencia para señalar lo relacionado con "el saberhacer o el desempeño en la acción". De todos modos, cabe anotar que aún expertos reconocidos los utilizan como sinónimos.

107 Para algunos analistas de las competencias, además de los saberes declarativo y procedimental, también están estructuradas por el saber para qué o saber ético, y por el saber contextual. Las competencias no solo sirven para constatar el nivel de desarrollo del bagaje adaptativo del cual goza un individuo en un momento dado, además ponen en evidencia lo "qué sabe hacer" potencial a fin de "ser-más" él mismo. También, como Ignacio A. Montenegro (2003: 19) El debate sobre las competencias. En: Revista Internacional Magisterio, (1). Colombia, Bogotá. Editorial Magisterio, el significado de éstas es sinónimo de habilidades, aptitudes, actitudes y destrezas, juicio que requiere matización y adecuación en cada contexto. Considera, también que las competencias básicas corresponden a las dimensiones de la persona humana: biológica, cognitiva, afectiva, política y trascendental, y que se orienta a garantizar la supervivencia humana, en tanto que patrones de "comportamiento" (Revista Internacional Magisterio, (1), 20). A la vez que las capacidades se desarrollan, según la dotación genética y hereditaria, también se aprenden, perfeccionan y maduran por medio de "procesos de transformación, diferenciados, regulados y coherentes" (Revista Internacional Magisterio, (1), 20-22). Si se quiere profundizar en el origen reciente del concepto competencia, en los discursos que lo utilizan con mayor recurrencia, en los significados que lo diversifican, en los objetos con los cuales se vincula, en las prácticas a las cuales hace referencia, y en las modalidades como se transforma, organiza y expande en la educación, además de cómo se recontextualiza en la oferta curricular el texto de GuiIlermo Bustamante Zamudio (2003), El concepto de competencia III; resulta adecuado tratándose del análisis, crítico y recontextualizado de las "competencias en la educación colombiana".

\section{Centrarse en la persona para que crezca en comprensión y en respuesta autónoma}

La salida humanística a la crisis de la educación superior invita a recuperar el protagonismo del sujeto que aprende en contexto de "realidad", para la transformación personal, socio-cultural y natural, como sujeto responsable consciente, libre y autónomo. Pues, no es suficiente con distinguir entre la vida, la conciencia y la reflexión para que los sujetos se hagan auténticamente capaces; transcurso imposible de llevar a cabo mientras se mantenga la alianza utilitarista entre poder y verdad, y que en occidente impide que la persona se haga presente a ella misma (Levinas, 2015, pp. 16-27 y 123-124) ${ }^{108}$.

\subsection{La pedagogía de la respuesta y de la pregunta constante}

Después de ahondar en la génesis griega y latina del término responsabilidad, y de proponer que se libere de la carga juridicista y moralista que lo constriñe a estos campos, J.J. Sedano (1996) resignifica su uso en el "horizonte de la formación humana"109 como capacidad

108 La vida que se abre a la reflexión, y la reflexión que se ocupa de la vida posibilitan la "comprensión", bien por el camino de las ciencias, bien por el camino de las letras o la creatividad estética, de todos modos orientada a la realidad, a lo concreto, así ésta se resista a la claridad, el camino de la realización demanda constancia en la búsqueda de compresión. A juicio del autor citado la verdadera "enseñanza" no se deja amaestrar, no confunde aprender con desvelar o revelar, saber con acción o actividad, la enseñanza no se deja aprisionar en la contemplación pasiva o en la quietud que neutraliza remitiendo al pasado. La verdad emerge como trascendencia en nuevas preguntas, como inadecuación entre "respuesta y pregunta". La enseñanza nos pone en condición de aprender la realidad, y también en condición de preguntar sin pretender acaparar, verdad o realidad; sin fundamentalismos argumentativos, pero, también sin caer en la irracionalidad, el misticismo charlatán o la fuga (Levinas, 2015, pp. 129-130).

109 La aproximación a la biografía de la palabra la emprende J.J. Sedano desde el uso cotidiano del término responsabilidad como "capacidad", "posibilidad" e "incumbencia" para hacerse "cargo de" o facultado para llevarlo a cabo, en tanto sujeto a quien se le exige hacerlo. De la raíz latina se aprovecha la riqueza de sentido que aporta a la formación, en cuanto que spondeo-re trae consigo la idea de compromiso, empeño y reciprocidad que se afianza en la respuesta. Recalca Fray J.J Sedano en la procedencia religiosocultual, tanto del término latino spondeo, como de spendo, de origen griego, ambos vinculados a las libaciones de consagración Sedano (2002, 163-171). Ahondar en la historia de las palabras posibilita salir al encuentro del especialista y el no especialista que la utilizan, la degradan o cargan de sentido desde diversas cosmovisiones. El desafío en el caso del concepto "competencia" obedece a que en la sociedad del control y del mercado puede ser utilizado 
de hacerse cargo de "sí y por sí mismo", de su realidad bio-psico-social, y de actuar con libertad, autonomía y consciencia en procura del bien común; requerido en dicho empeño por su propia naturaleza humana. Para J.J. Sedano el sentido antropológico, histórico y socio-cultural de la responsabilidad humana, si bien por sus condicionamientos físicos, biológicos y de especie prolonga el arraigo con la naturaleza a la que pertenece, no puede ser instrumentalizado, reducido a medio o tratado como objeto por su desemejanza, singularidad y "condición de absoluto límite"110.

La capacidad de "ser-más" o de crecer impele al ser humano para que se haga cargo de sus potencialidades, dinamismos o facultades, y se personalice "desplegándolas y acrecentándolas de manera consciente y autónoma en contextos específicos de acción"; lo que le implica "vivir a cuenta propia", asumiendo los riesgos de responder por sí mismo, ante sí y frente a los otros.

Fray J.J. Sedano explicita las dinámicas y potencialidades que se desenvuelven en la formación humana, y que al desplegarse perfeccionan, superan, corrigen o innovan capacidades siempre con base en lo alcanzado, sin que se concluya definitivamente, con miras a la personalización de los sujetos siempre "más capaces de ser", así: "el sentido de la vida es realizable, si soy responsable; soy responsable personalizándome, definiéndome con autonomía al comprometerme por decisión propia"111. El camino

para esclavizar y estandarizar, así nos lo recuerdan Pablo González y Marcos Roitman (2006, 199-217).

110 Los aportes que hace la antropología teológica cristiana dese la "fe" que guía a la inteligencia, resultan oportunos y enriquecedores cuando se trata de formar en todas sus dimensiones a la persona humana, según perspectivas que abren otros horizontes de significación. El testimonio de Edward Schillebeecks (1995) es aleccionador en este sentido. La invitación de J.J. Sedano a confrontar QQ.DD De Potentia, q. 9, a. 3:2 (cita 95 de Pedagogía de la respuesta, 2002, 172), contribuye a clarificar el significado de "capacidad".

111 El texto original propuesto por Fray J.J. Sedano (2002, p. 174) alerta sobre aquello que dificulta avanzar en la personalización; en consideración a esto lo describe así: "No puedo realizarme sin responsabilizarme, no puedo responsabilizarme sin personalizarme, no puedo personalizarme sin definirme, no puedo definirme sin autodeterminarme, no puedo autodeterminarme sin comprometerme, no puedo comprometerme sin decidirme" (la cursiva es nuestra). La de la respuesta personalizante lo vincula con la capacidad del sujeto para cuestionarse crítica, autónoma, libre y conscientemente.

\subsubsection{La praxis docente en perspectiva tomasiana}

El supuesto pedagógico que orienta la praxis docente en la Universidad Santo Tomás, tal como se recoge en el texto del proyecto educativo institucional, se fundamenta en el realismo metodológico tomista, da primacía al sujeto cognoscente; reconoce el estatus epistémico de cada una de las disciplinas; aprovecha en el enfoque crítico del devenir de cada una de las ciencias a fin de contextualizar la construcción del conocimiento en el momento histórico; promueve la capacidad indagadora que problematiza, observa, discute, sintetiza y avanza hacia nuevas comprensiones; de igual manera, la apertura dialógica a nuevos mundos de sentido y desarrollo cultural; da pie a la autocrítica del propio saber ser, saber conocer y saber actuar; tiene en lo asociativo y comunitario el contexto que propicia la construcción de nuevas comprensiones $y$, sobre todo, promueve la capacidad de auto aprendizaje, el cuestionamiento libre y la responsabilidad que trasforma la realidad y hace justicia por medio del conocimiento ${ }^{112}$.

apertura a la "enseñanza", según el significado que le asigna Levinas, (2015, pp. 128-151), demanda dar cabida siempre a la conversación, a la discusión en torno a la cotidianidad, a la vida misma de las personas antes que a los libros. Aun así, para quien se propone actuar con libertad y responsabilidad, es indispensable tener en cuenta que así se trate de volcarse al exterior comprometiéndose totalmente, el "yo" del sujeto permanece en sí mismo; "los actos pueden trasladar al "yo" a otro ambiente pero el "yo" va consigo mismo"; "me llevo a mí mismo en mi trascendencia, mis actos no me convierten en otro "yo" ni comprometen mi identidad". En este sentido, "el ser humano se reconoce en lo nuevo que brota de él, se reencuentra como poder y dominio en el ejercicio de su libertad, caminando de la incomprensión a la comprensión, y de la no verdad a la verdad de manera errática".

112 El ideario educativo institucional al cual se hace referencia recoge de la tradición del humanismo tomista lo atinente a la pregunta de si un hombre, ¿puede o no puede enseñar a otro? (S.T I, q.117, a.1.), que aparece en otras de las obras del Aquinate, a saber: In Sent. I.2 d.9 a.2 ad 4; d.28 a.5 ad 3; De Verit. A.11 a.1; Cont. Gentes 2,75. Para Santo Tomás, el maestro puede contribuir de dos maneras al ejercicio del conocimiento del discípulo. La primera, suministrándole algunos medios o ayudas de los cuales pueda usar su entendimiento para adquirir la ciencia. Y la segunda, fortaleciendo el entendimiento del que aprende, no mediante alguna virtud 


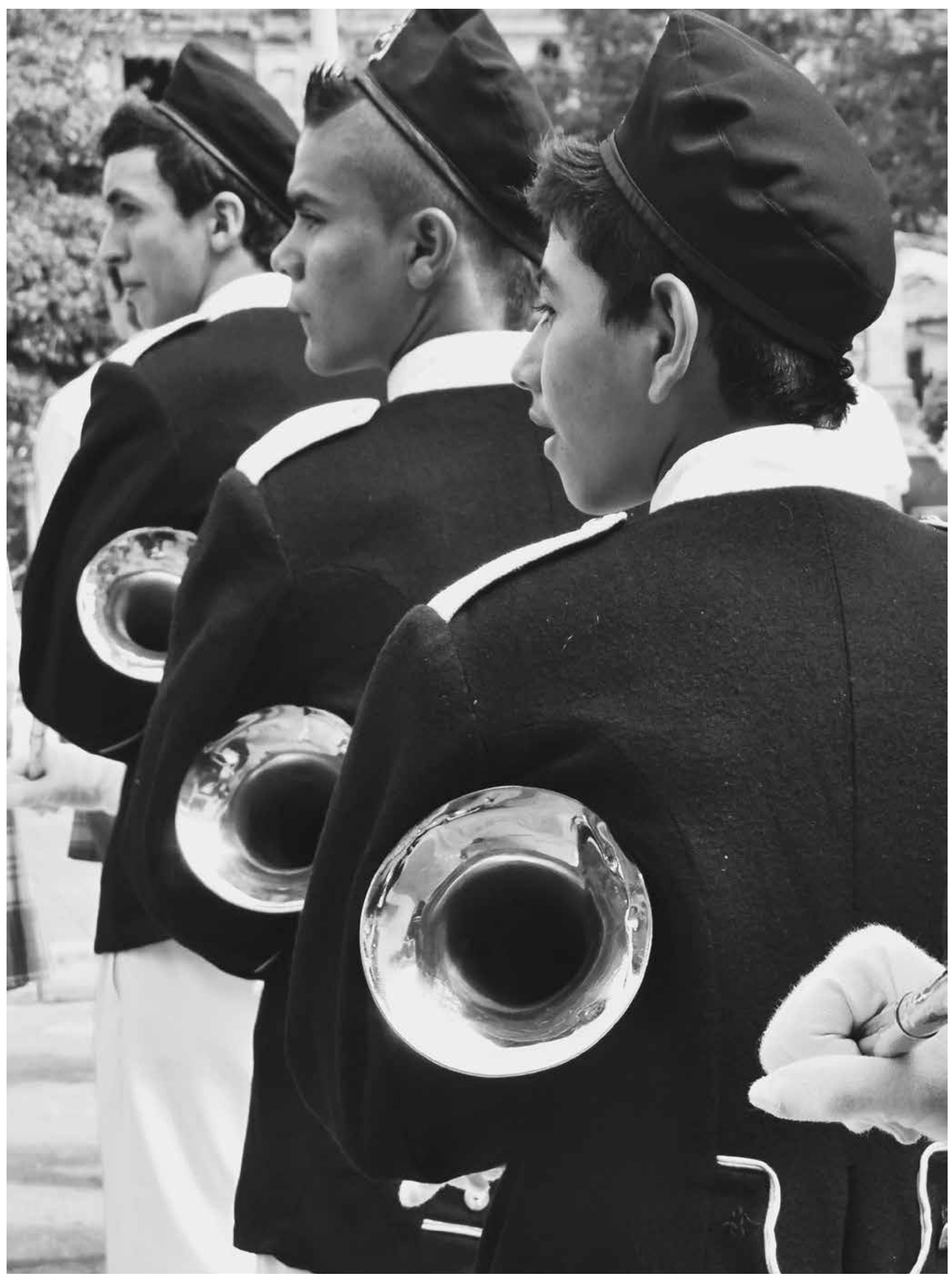


La dimensión problémica de la pedagogía tomasiana y las notas que la caracterizan se fundamentan, sobre todo en la capacidad crítica del maestro, en el aprendizaje reflexivo que propicia y en la estructura sistémica y dialogal de las "cuestiones" propuestas por el Aquinate en sus obras. La dinámica problematizadora de la pedagogía tomasiana integra la memoria de las experiencias adquiridas; el sentido interior de un fin particular; la atención a los que saben o han vivido más; la pronta atención a las coyunturas; la investigación racional, progresiva; la habilidad de prever el porvenir, pro-videncia y sus contingencias; la contextualización de las oportunidades, el examen de las circunstancias y discernimiento de lo favorable; el razonamiento que compara; la precaución en las complejidades y el discernimiento de las condiciones excepcionales. Notas que se aproximan a los conceptos de dinamus, facultas y habitus, de raíces aristotélicas que sirven de fundamento, tanto al enfoque formativo tomasiano, como al de desarrollo humano integral por capacidades.

La capacidad dialógica fundamenta la concepción tomista de la razón práctica, guiada por la frónesis, y orientada a ejecutar la acción formativa correcta en el contexto de contingencia histórica concreta, de la cual hay que hacer memoria, y echar mano para sembrar el futuro deseable y posible. Pero, ya que la razón práctica de un sujeto contingente no puede ser infalible en cuanto al conocimiento de la realidad, también, contingente (S.T I-2, q.57, a.5),

activa como si el entendimiento del que enseña fuese de una naturaleza superior, puesto que todos los entendimientos humanos son de un mismo grado en el orden natural, sino en cuanto que se hace ver al discípulo la conexión de los principios con las conclusiones por medio del uso de la demostración. Más adelante en el mismo artículo Santo Tomás afirma que el maestro por la enseñanza mueve al discípulo para que él por su propio entendimiento forme las concepciones inteligibles, cuyos signos le propone exteriormente. Por esta razón se enfatiza en la pedagogía autodirigida y responsable. Las categorías de educabilidad y enseñabilidad se remiten al significado que para Santo Tomás tiene el Tradere o método de relación interactiva basado en la capacidad del dar, que se complementa con el investigare o capacidad de buscar los vestigios, de descubrir, de indagar a fin de construir la verdad. La educabilidad y la enseñabilidad se relacionan de manera recíproca y simbiótica de manera simultánea y dialéctica. De aquí que este dinamismo educativo se considere hoy como integral. entonces se requiere de la frónesis para que guíe al sujeto en la construcción de modelos de realidad, accesible por medio de procesos dialécticos y analógicos, dinámicos, impredecibles e históricos.

Para el Aquinate la razón axiológica es un proceso histórico de construcción de "la verdad", dado el interés de la razón práctica ( $I$, q.79, a.Il ad 2), puesto que la verdad construida y la razón están ligadas a las "acciones" en cada contexto particular están ligadas, surgen de las situaciones y demandan del sujeto ejercer la capacidad de juzgar entre opciones concurrentes (ST I-2, q.57, a. 4).

En la práctica educativa, el razonamiento ético y el juicio sobre lo mejor se requieren mutuamente y se desarrollan de manera simultánea. Para Tomás, el acto humano no puede darse sin frónesis, dado que este habitus posibilita elegir (ST I-2, q.58, a. 4). En consecuencia, para juzgar la praxis educativa correcta, no es suficiente conocer los principios generales de lo pedagógico o los principios específicos de cada disciplina, se requiere claridad acerca de los objetivos particulares de cada acción en cuanto dinamismo ajustado a la razón crítica y al parecer de los que mejor conocen acerca del saber en desarrollo (ST I-2, q.58, a. 5). La tesis central de Right practical reason, obra de Daniel Westberg, se refiere a que el intelecto y la razón son interactivos en el proceso de la acción y que, por tanto, es erróneo pensar que primero la razón conoce los bienes y que después la voluntad elige. Westberg sostiene que, para el Aquinate, "la verdad" ética se encuentra no en la aprehensión, sino en el proceso de juzgar que conduce a la acción. De aquí que la acción es el objetivo principal de la razón práctica, frónesis del juicio ético, en definitiva, de la dinámica como se integra razón, voluntad y acción con el juicio valorativo que sucede en el aula.

La razón práctica o hermenéutica satisface el interés por el conocimiento que juzga, que elige y concreta en acciones los bienes sociales 
y del conocimiento que el sujeto humano considera significativos e indispensables para su realización, para las relaciones intersubjetivas y para el disfrute de la equidad. Es indispensable, pues, que en las prácticas pedagógicas y en la gestión del currículo se evidencie la interdependencia entre el conocimiento, el proceso de escogencia de los saberes más avanzados y las razones por las cuales se eligen las acciones que hacen evidente el beneficio elegido. Para el Aquinate, la convergencia entre la naturaleza dialéctica del conocimiento ético, el compromiso y la acción es posible en la construcción de nuevos marcos de sentido, cuando, a la vez conocimiento y deseo tienden a lo solidario.

Al respecto, en la "pedagogía de la respuesta", que resignifica la alternativa educativa desde la fuente tomista, J.J. Sedano (2002) se interroga acerca del núcleo central de la formación humana y de los roles que desempeñan cada uno de los responsables de la misma. Al inicio analiza y diferencia entre la pedagogía de la imposición y la pedagogía de la espontaneidad; indaga luego, por la alternativa que ofrece el realismo pedagógico tomasiano, como dinamismo de construcción de capacidades forjadas con autonomía, consistencia y esperanza, según la alternancia de roles que abre a la posibilidad de ser maestro y estudiante al mismo tiempo que se "forma, formándose" con la participación de los otros. La consciencia de la incompletud y la precariedad disponen a la relacionalidad, y la demanda de apoyo para el aprendizaje.

Para J.J. Sedano (2002) la intencionalidad de la educación es la formación de la libertad en el ejercicio autónomo y comprometido de la responsabilidad: "Todo auténtico proceso educativo implica un continuo desarrollo de la primordial tendencia de auto-afirmación y de auto-entrega de tal modo que el educando sea capaz de irse realizando hasta prescindir del maestro". Es decir, capacidad de responder de sí mismo, de dar la propia, personal e intransferible respuesta a su propio personal e intrans- ferible compromiso, al que se accede a través del ejercicio de la pregunta, motivado por auto-convicción y autodecisión de construirse en libertad (ST I-2, q.1 aa. 2-3), y para lo cual se requiere desarrollar la capacidad personal de disciplinarse y comprometerse con la realidad (ST, II - II, q. 49, a.31), como ejercicio consciente de autodominio (ST I-II, q.1, a. 2 y 3).

Continúa el análisis de Sedano (2002) haciendo énfasis en la necesidad de formar la capacidad de juicio crítico, en tanto indispensable para la autonomía en la acción desde una cosmovisión personal o síntesis vital que le permita, problematizar, enjuiciar, reflexionar y transformar las propias convicciones con esfuerzo y en coherencia consigo mismo y con la realidad. Capacidad de juicio que se conjuga con el sentido de creatividad o inventio cuando se trata de dar respuestas nuevas a nuevos problemas (QQ.DD. De Veritate, q.11, aa. 1-2, ST I, q. 117, a. 1).

Dado que el modelo predominante en la formación del profesional docente modula las "teorías implícitas" que, acerca de la pedagogía y de la práctica, guían su praxis, se hace indispensable aclarar los tipos de contenidos que tiene el concepto de "teoría" en el contexto de la educación, contribuyen a este propósito los aportes de Kessels y Korthagen (1996) quienes retoman la episteme y la frónesis aristotélicas para aclarar el significado de dicho concepto. La teoría, en tanto episteme, tiene que ver con conceptos generales y elaboraciones discursivas de conocimiento basado en principios y leyes que pretenden ser "objetivos". Esta concepción ha orientado la práctica docente tradicional. Por el contrario, la frónesis tiene que ver con el conocimiento específico construido en un contexto particular, y que posibilita a los sujetos avanzar poco a poco en la comprensión de situaciones relevantes. En dicho sentido la frónesis es teoría de carácter más perceptual que conceptual, puesto que enfoca la atención del actor en cada situación, característica o proceso. Mientras que la episteme aporta una visión 
general, la frónesis guía la acción bajo los principios de utilidad, significatividad y previsión. Ambos tipos de teoría deben complementarse a fin de evitar que se caiga en el abstraccionismo de la episteme o en el pragmatismo utilitarista de la frónesis, sobre todo cuando se trata de la construcción de capacidades y competencias humanas.

Acerca de la pregunta por las relaciones entre cognición y comportamiento pedagógico docente, Korthagen y Lagerwerf (1996) proponen una explicación integradora entre la episteme teorética y la frónesis o teoría en acción. Se basan en los desarrollos de la neurofisiología, la lingüística, la psicología social y la psicología cognitiva y apuntan al papel central de los esquemas mentales figurativos en la construcción de significado y en la dirección del comportamiento. Dentro de este marco se entienden nociones como imágenes, teorías personales, reflexión, efecto de barrido, inquietudes de aprendizaje, cambio conceptual y capacidades combinadas.

En las situaciones inmediatas de enseñanza, es imposible separar la percepción de la interpretación y de la reacción, porque todo ello sucede de manera simultánea como una unidad significada a partir de experiencias similares. Esta unidad de percepción, interpretación y acción no tienen porqué suceder de manera consciente, pues algunas de las posibles causas de su aparición pueden ser sentimientos, experiencias similares anteriores, valores, conceptos del rol, necesidades o inquietudes y rutinas. Todos estos puntos construyen el significado personal de una situación y median el desarrollo humano. A esta unidad dinámica y holística de necesidades, sentimientos, valores, significados e inclinaciones comportamentales en situación particular se le conoce como Gestalt o forma elemental en la que el individuo adquiere la comprensión de sí y del otro, y el entendimiento del medio ambiente.

Si los aportes anteriores de Kessels y Korthagen se integran a los desarrollos actuales que J.J. Sedano (2002) propone a cerca de los rasgos fundamentales y los propósitos de la educación en Santo Tomás con miras a responder a las necesidades actuales que enfatizan en la autonomía del estudiante en su proceso de construcción del conocimiento, entonces habría que ubicar el eje dinamizador de la educación tomasiana en la responsabilidad entendida como: la capacidad de hacerse cargo de sí mismo, de los otros, del Otro y de la realidad ${ }^{113}$. El énfasis que hace J.J. Sedano (2002) sobre la responsabilidad como capacidad de responder al empeño asumido y a la exigencia de respuesta en virtud de la palabra comprometida ${ }^{114}$, obedece a la concepción de la responsabilidad o frónesis como dimensión personalizante dentro de la antropología de Tomás de Aquino, dado que: el hombre emerge, divergente, como punto de convergencia, síntesis o microcosmos, del universo. Así, por una parte, está arraigado en el mundo y, por otra, como vértice $u$ horizonte por ser persona, es lo más perfecto en la totalidad de la naturaleza: semejanza y desemejanza, continuidad y novedad, inmanencia y trascendencia ${ }^{115}$.

Dentro de los aportes que J.J. Sedano (2002) hace a la educación desde la relectura toma-

$113 \mathrm{Al}$ analizar el campo semántico de la categoría responsable J.J. Sedano (2002) diferencia de manera sutil entre esta y respondible en tanto que este término califica la pregunta que puede ser respondida, y responsable califica a la persona que puede responder, para afirmar a continuación que la responsabilidad entraña la condición personal como capacidad de responder y el matiz de exigibilidad de la respuesta ante un requerimiento. Pero según el autor es la etimología latina la que nos remite a un sentido aún más denso y rico de la categoría, si se tiene en cuenta que spondeo quiere decir empeñar, prometer la propia palabra, comprometerse de manera formal y solemne o compromiso. El re-sponde es la acogida, empeño o compromiso que se refiere a la reciprocidad que conlleva el concluir un pacto mutuo.

114 Sedano ahonda en el origen de spondeo y lo asocia al uso popular que los latinos le dieron a sponte, de donde deviene "espontáneamente", que equivale a "voluntariamente", quizás para caracterizar la calidad libre, sin coacción y consciente del compromiso. El sentido de la responsabilidad tiene para Sedano su raíz original en un núcleo ético mítico que, al filo de las experiencias humanas convertidas en tradición, se va enriqueciendo y lentamente conformado su significación integral.

115 La semejanza, según Sedano (1996), hace del hombre una realidad en continuidad con la naturaleza, sometido a sus leyes y condicionamientos. Interpretación que viene desde Aristóteles y que en la actualidad es socorrida por la razón científica y técnica pero más allá del discurso científico y técnico está la singularidad o desemejanza. 
siana, identifica el dinamismo central de la responsabilidad en cuanto vehicula la construcción de capacidades y libertades educables, así: no puedo personalizarme sin responsabilizarme; no puedo responsabilizarme sin definirme; no puedo definirme sin autodeterminarme; no puedo autodeterminarme sin formarme para la respuesta, libre, consciente, y comprometida; y no puedo formarme para la respuesta libre y consciente sin comprometerme ${ }^{116}$.

La propuesta personalista de J.J. Sedano se articula con los aportes del enfoque comprensivo de Bernard Lonergan (2002), pues ambos por su origen aristotélico-realista, y tomasinopersonalista, examinan las implicaciones que tiene para el sujeto ser el autodeterminador responsable de su propia educación. Empero, la propuesta de Lonergan se distancia por su concepción kantiana de la conciencia, del realismo-responsivo elaborado por J.J. Sedano, con fuerte raigambre tomasina. Además, como se analizará en el siguiente apartado, la contribución de estos dos pensadores personalistas a la propuesta de formación integral por capacidades y competencias de Nussbaum (2012), se resignifica de cara a la dimensión política de la educación concebida dentro del marco constitucional y democrático vigente en Colombia.

116 Todas las notas características de este dinamismo acontecen a la vez, pero con mayor fuerza unas respecto de otras, según la situación y el proceso de autonomía alcanzado por el sujeto; de aquí que el comprometerse se relacione primordialmente con la realidad histórica o realidad ambiente, de lo cual se genera la autopresencia y el encuentro consigo mismo que conduce a la autopertenencia y a la necesidad de preguntarse y responder por lo económico, lo social, lo político, lo cultural y lo religioso. Este comprometerse es también con los otros y es un modo de aprender respondiendo cómo darse a los demás en búsqueda de la respuesta que solo puede venir del otro y que se realiza como un corresponder. Así mismo, afirma el autor que nadie puede realizarse sin personalizarse, nadie puede realizarse sin liberarse, entendida la libertad como tarea comprometida con los otros. También el comprometerse significa estar en tensión entre la univocidad como enajenación de la identidad y el escollo de la equivocidad o coexistencia en paralelo que no permite el encuentro con el otro. Solo desde la precariedad de la condición humana aceptada en libertad emerge el dinamismo de comunión interpersonal como dinámica de educación humana. Pero solo en las decisiones se explicitan los compromisos cuando se asume la propia respuesta sin abdicar a la propia historia.

\subsection{La Formación comprensiva personalizante}

Los modelos pedagógicos como el constructivismo, el conceptualismo o los liderados por influencia del neocapitalismo, ponen como centro de la enseñanza los contenidos, la memoria, el docente y la consecución de objetivos y metas que correspondan a los estándares de calidad, determinados por el enfoque eficientista y rentable de la educación; salvo excepciones valiosas como las orientadas hacia la personalización, aún se perpetúa en la universidad el modelo tradicional educativo magistral, memorístico, repetidor de contenidos y centrado en el poder de la evaluación. Los efectos de dicho modelo saltan a la vista en los resultados deficientes de las pruebas Saber Pro.

El giro hacia lo socio-formativo ${ }^{117}$ en educación superior se impone, a fin de que se garantice al estudiante el protagonismo de su desarrollo integral; por lo tanto, centrar la oferta educativa en las personas implica para la institución hacer del respeto por la dignidad humana, la libertad, la autonomía y la responsabilidad un rasgo identitativo de su oferta humanística basada en la ética dialógica.

El punto de partida es "el mundo de la vida", contexto de la experiencia personal y colectiva, de la diversidad y de las relaciones intersubjetivas que constituyen lo social. En este nivel se conversa, se intercambian ideas, se dialoga y se tiene comprensión directa de lo que sucede en la realidad. La posibilidad del encuentro con to-

117 La contribución del interaccionismo simbólico a las alternativas de formación integral se desprende del carácter socio-cultural de la educación, de la mediación del lenguaje y de la interrelación con los otros como posibilitadores en la construcción de la identidad de los sujetos individuales y colectivos. Según Herbert Blumer (1982) los principios por los cuales se orienta el interaccionismo simbólico son los siguientes: "el ser humano orienta sus actos hacia las cosas en función de lo que éstas significan para él"; "la fuente de ese significado es un producto social, que emana de y a través de las actividades de los individuos al interactuar"; y que "la utilización del significado por el agente, se produce a través de un proceso de interpretación propia, que supone auto interacción y manipulación de significados" (Blumer, 1982, Prólogo). 
dos desde sus mundos de vida aporta sentido a la vida propia ${ }^{118}$.

Las experiencias formativas de integración e interrelación de las personas y los grupos humanos, hacen posible que la pluralidad, la multiculturalidad y las diferencias sean integradas al mundo de la vida como realidades que posibilitan el desarrollo humano y la construcción de nuevas interrelaciones. En vínculo con el Estado, la universidad contribuye a la estructuración del "horizonte común" de lo público, a la construcción plural del proyecto de sociedad que integra a todos los ciudadanos en equidad e igualdad de derechos y deberes (Garay, 2002, p. 143).

Por igual, a la universidad le compete el estudio del fenómeno de la corrupción pública y privada, oficial y no oficial, pues el olvido de la formación de los sujetos políticos en la ética de lo público, ha devenido en clientelismo gamonal y en deseo de lucro con los recursos de todos. De aquí que sea indispensable favorecer la construcción de capacidades y competencias comunicativas, deliberativas y de participación en la democracia (Garay, 2002, p. 144). Sin la fortaleza de lo público no puede ser fuerte el estado de derecho social, el desarrollo de lo comunitario y la sociedad civil. Formar capacidades para la crítica reflexiva, la organización social y la militancia política responsable, facilitan la comunicación entre distintas perspectivas de lo público y lo político, con lo cual se fortalece el Estado y la institución universitaria (Garay, 2002, p. 144).

La universidad está llamada al fortalecimiento de las entidades del Estado, contribuyendo a la formación de profesionales competentes para el diálogo que alimenten acuerdos, arbitren los disensos y atienda a que todos sean escuchados, a que el argumento se fundamente en el bien de todos, en lo ético y en el bien común.

118 Acerca de las alternativas pedagógicas para el desarrollo de capacidades y competencias humanas que favorezcan la paz y la democracia, los expertos colaboradores del estudio Repensar a Colombia (2002, pp. 136-149) proponen que algunos procesos pueden adecuarse a la estructuración de la cátedra de paz y convivencia (Garay, 2002).
Tener claro que los derechos humanos deben ser reconocidos, respetados y promovidos por todos, dentro y fuera de la universidad, eleva la posibilidad del consenso político en torno al papel que esta institución cumple en la transformación del Estado (Garay, 2002, p. 144). Con el anterior propósito, tres componentes articularán la institución universitaria, a partir de la razón comprensiva y de la ética comunicativa propia de las relaciones interculturales, a saber: la ética del discurso, la deliberación política y la participación democrática, que comprometen en la construcción del bien común (Garay, 2002, p. 145).

Aprender a discutir, a debatir y a flexibilizar las perspectivas y los enfoques integrando los intereses de otros o modificando los propios en función del acrecentamiento de la dignidad, la libertad y el conocimiento conduce a la toma de conciencia de lo que debe ser asuntoproblematizado por medio de la investigación, la docencia y la extensión, sin protagonismos dogmáticos o vetos a lo inabordable en el debate universitario. Ampliar las posibilidades de confrontación académica para indagar, investigar y encontrar soluciones razonables, democratiza el ambiente universitario, amplía los horizontes transdisciplinares y genera acuerdos razonables de solución (Garay, 2002, p. 145).

Para lograr lo anterior, no es suficiente el aprendizaje de las reglas, el cumplimiento de las normas y el ajuste a los rituales sociales establecidos en el ámbito universitario. Hace falta crecer en convicciones de compromiso y respeto a los derechos humanos y de democratización participante e incluyente en todos los aspectos del proyecto educativo de tercer nivel, tanto en lo concerniente a lo representativo como en la implementación de procesos que regulen la participación, las etapas de diagnóstico de problemas, el trazado de los objetivos de desarrollo integral, la veeduría de los avances, desempeños y mejoramiento cualificado, tal como lo demanda hoy el sistema de autoevaluación, acreditación, regulación y certificación universitaria (Garay, 2002, pp. 146-149). 


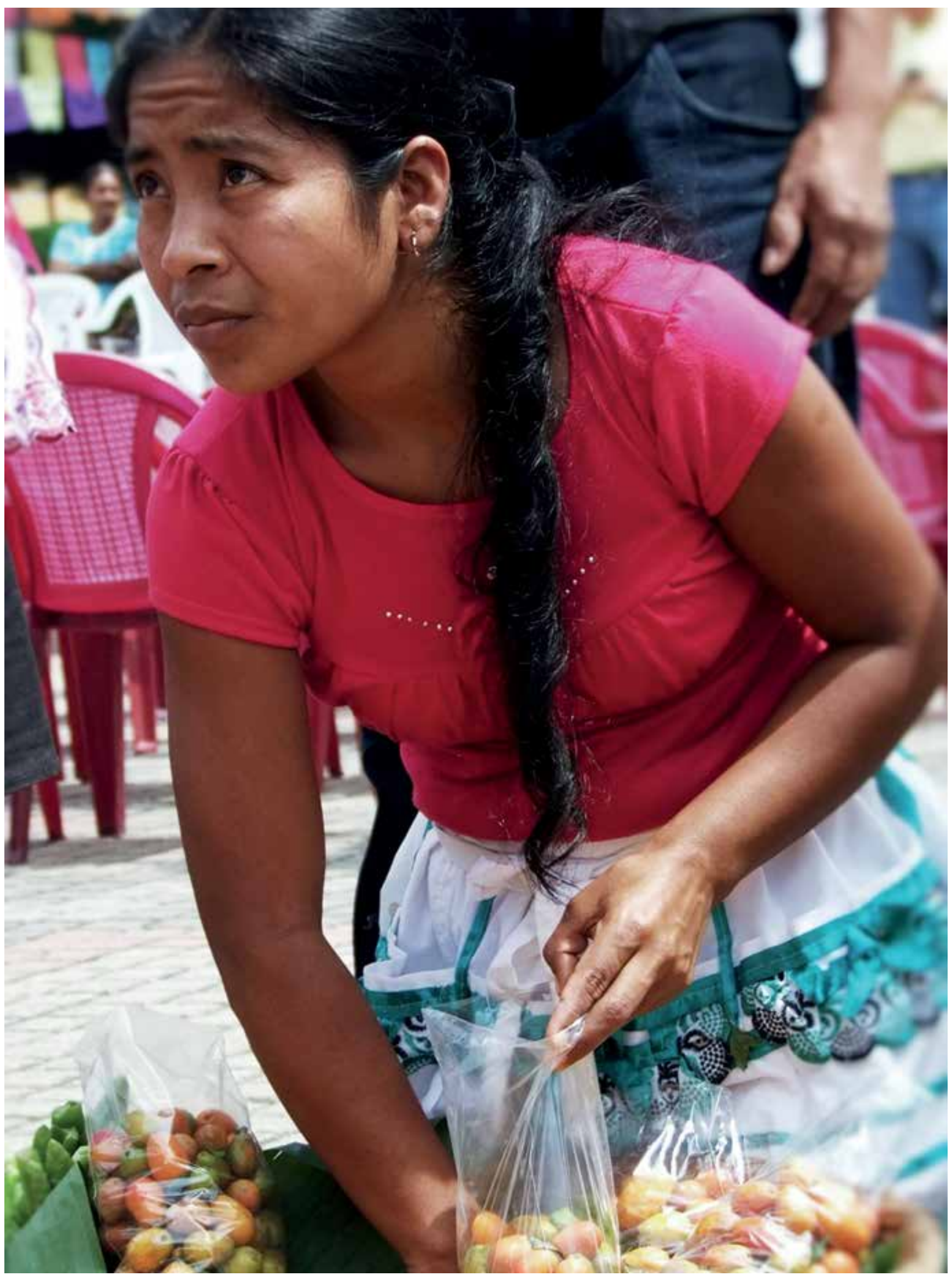




\subsection{La formación responsivo-comprensiva, alternativa de pedagogía personalizante}

Además de la formación de profesionales capaces y competentes en sus ámbitos de conocimiento y desempeño, la prioridad de la educación de tercer nivel es la trasformación del ethos cultural colombiano ${ }^{119}$. Desafío que implica adoptar y fortalecer los modelos pedagógicos que propician la toma de conciencia acerca de las causas históricas del conflicto armado y de la guerra entre compatriotas; por consiguiente, que sean capaces de contribuir con el cambio de los modelos de representación, percepciones, creencias, valores y marcos de sentido tradicionales que impiden la construcción de alternativas de convivencia en paz y democratización del conocimiento.

Para lograrlo, la propuesta de personalización que ofrece la universidad se fortalece, actualiza y perfecciona con la alternativa de desarrollo humano integral por capacidades de M. Nussbaum (2012), la perspectiva responsiva y comprensiva de personalización de J.J. Sedano y Bernard Lonergan (1992), respectivamente, y el enfoque de complejidad de Edgar Morin; a fin de que la universidad contribuya a la transformación del ethos político del pueblo colombiano, haciendo del conocimiento y el servicio profesional eje cualificador de la democracia social de derecho para la convivencia en paz ${ }^{120}$.

Para Lonergan (1992) el desarrollo formativo de capacidades y competencias humanas implica en un primer lugar el contacto directo con la realidad, la sensibilización, la captación di-

119 Para que los otros sean asumidos como otros no reducibles a mis intereses ni instrumentalizables.

120 La tradición humanista identificada con los propósitos culturales de la universidad que nace de la modernidad, sobre todo por el influjo alemán, encuentra en el concepto de Bildung, el término más adecuado para referirse al patrimonio personal que potencia, despliega o adquiere un sujeto como fruto del trabajo cultural y del desarrollo del espíritu. Por consiguiente está vinculado con la enseñanza y la formación de capacidades y competencias. Considera Gadamer (1997, 38-74, vol. I), que el humanismo, además del concepto formación, al cual se hace referencia, también comprende el de sensus communis, capacidad de juicio y gusto estético. recta de los hechos, el vínculo con las personas y el reconocimiento de los problemas. A dicho primer encuentro con la realidad, Lonergan lo considera indispensable para avanzar desde el insight directo hacia la conceptualización y elaboración interpretativa de los hechos por medio de los discursos, teorías, y explicaciones que aportan a los sentimientos y al contacto sensible con la realidad, la elaboración conceptual-comprensiva, para que preguntándose de nuevo se cuestione por la realidad, se indague por los hechos, se valoren las evidencias y se hagan preguntas honestas que induzcan al sujeto a establecer la veracidad.

Alcanzado el conocimiento conceptual de los hechos es indispensable de nuevo plantearse la pregunta por la dimensión y complejidad de las situaciones, por las diversas interpretaciones y caminos de abordaje, a través de procesos reflexivos y críticos que conduzcan de lo conceptual a lo razonable, es decir, al establecimiento de juicios, después de valorar las evidencias, y debatir para la toma de decisiones.

Por medio de este proceso se logra insight reflexivo. Sin embargo, la construcción consciente del conocimiento implica la deliberación o etapa de valoración con miras a garantizar la toma de decisiones, la elección, el compromiso y las acciones coherentes con la postura crítica y ética. Por eso, al tomar decisiones el sujeto se involucra preguntándose qué implican estas para mí. En este proceso se involucran la autenticidad y la auto-trascendencia, evidentes en las acciones y en la opción personal. Cada uno de los niveles experiencia, entendimiento, juicio y decisión abren mayores espacios de libertad, significación y sentido de vida.

- Nivel de experiencia sensible - empírico

Los seres humanos no captan la realidad tal y cual ella es. Elaboran traducciones, representaciones y reconstrucciones a través de procesos de codificación y decodificación efectuados por los sentidos. Por eso, al perci- 
bir siempre se corre el riesgo de equivocarse o cometer errores. Para conocer se necesita interpretar a través del lenguaje y estar al tanto de que sea razonable, construido entre varios, y crítico. Cuando se aborda la propia realidad o la realidad de otras personas es imposible librarse del afecto o de los prejuicios que sentimos frente a estos, de aquí que las percepciones que elaboramos corran el riesgo de ser erróneas. Tanto el mucho afecto como la exagerada racionalidad o el interés instrumental impulsan al error (Morin, 2000, pp. 15-25).

Ignorar los mundos de vida de los demás nos dificulta la sensibilidad frente a lo incierto o frente a lo que nos causa temor. El culto a la imagen personal, al nivel de clase o de formación impide hacerse sensible a las fragilidades de los demás. La venganza y el rechazo del enemigo como imperativo comportamental de ciertos grupos humanos insensibilizan la percepción de otros mundos. El egocentrismo, es decir, la autoreferencialidad inconsciente y mecánica, induce a la autojustificación, autoglorificación, a la mentira y a la proyección de los propios errores en los demás; de aquí que el egocentrismo sea incompatible con la construcción de sujetos razonables (Morin, 2000, pp. 69-72).

- Nivel Intelectual - conceptual

Así como los sentidos conducen a percepciones engañosas, también el egocentrismo y la urgencia por expresar los propios juicios hacen que proyectemos en los otros la causa de todos los males: nos mentimos a nosotros mismos, proyectando nuestros propios engaños en los demás. Aún los recuerdos se degradan y desfiguran la realidad, pues el principio de economía cognitiva hace que rechacemos lo no conveniente, excluyamos lo que nos sanciona y acentuemos lo que obra a favor de nosotros. Más de una vez los falsos recuerdos nos llevan a evocar lo que nunca hemos vivido. Las teorías, marcos de referencia y sistemas de valores, además de abocarse al error, encubren los errores, pues en el momento de seleccionar la infor- mación y los datos descartan casi siempre las teorías y los conceptos adversos a los propios, sobre todo cuando se trata de paradigmas y doctrinas prescriptivas, suficientes en su propia verdad (Morin, 2000, p. 16).

La dinámica simplificadora del entendimiento elimina y reduce las posibilidades de comprensión de los hechos, tanto en las dimensiones positivas como negativas y obstaculizan la regeneración de lo humano (Morin, 2000, p. 73).

\section{- Nivel: Reflexivo - crítico}

La razonabilidad se orienta a descartar el engaño, a superar lo subjetivo e imaginario, a controlar los hechos; a verificar en la práctica si las cosas son como aparecen; a superar el sentido común y los prejuicios o pre-comprensiones de la vida cotidiana $y$, sobre todo, a confrontar con otros las maneras de ver la realidad; además, a través de procesos y operaciones lógicas la razonabilidad corrige y hace fiable lo que se verifica. En consecuencia, para hacer juicios es indispensable facilitar la razonabilidad constructiva fundamentada en mundos de interpretación, coherentes, verificables, lógicos y compatibles con las afirmaciones y los hechos. Por eso, formar agentes razonables es promover la lógica de la discusión, la ética dialógica y crítica que duda aún de la lógica de la propia razonabilidad puesto que con cierta frecuencia se argumenta con falsedades, medias verdades o falta de verificación. Es oportuno diferenciar racionalización de racionalidad, dado que la racionalización es cerrada, instrumentalizadora y negadora de otras perspectivas de verdad; en cambio, la racionalidad es abierta, flexible, cambiante, contextual e incluyente. Por eso, la racionalización adoctrina y la racionalidad incentiva la opción autónoma movida por el afecto, la compasión, la gratuidad y el deseo de corrección (Morin, 2000, pp. 17-18).

La introspección como práctica constante de la toma de conciencia acerca de los aciertos, desaciertos, coherencias, incoherencias, menti- 
ras y modos de violencia personales, contribuye al crecimiento individual de cara a la comprensión imaginativa frente a los demás. Aceptar la fragilidad, vulnerabilidad, singularidad y condición perfectible posibilita que seamos indulgentes al juzgar a los otros. Ser consiente de sí mismo es el primer paso para la aceptación de los otros, aún en aquellos juicios, expresiones y actitudes que no son compatibles con los propios intereses. El camino que recorre la tolerancia desde la actitud noble frente a los derechos de los otros, la apertura al disenso y a la diversidad, avanza por la aceptación de las verdades antagónicas a las propias hasta llegar a la toma de conciencia de lo que enajena y esclaviza a los demás sin pretender destruir al enajenado o esclavizado (Morin, 2000, pp. 74-75).

\section{- Nivel: Ético - deliberativo}

Los seres humanos constituidos por la triada individuo, sociedad y especie según las interacciones que se establecen, se religan a estas realidades haciéndolas inseparables, demues- tran cómo las acciones humanas individuales afectan a la sociedad y a la especie humana. Por consiguiente, es imposible favorecer el desarrollo de los procesos de conocimiento e investigación sin incluir las relaciones entre los sujetos y las comunidades, y entre estos y la posibilidad de la vida en todas sus manifestaciones.

La democracia universitaria se fortalece por la diversidad de personas, culturas e ideas que integran la comunidad de aprendizaje, y sobre todo, por la protección de las minorías divergentes. Así, cuando emergen los conflictos de ideas científicas y se contraponen las opiniones, se activan los diálogos y se fortalece la democracia formativa por medio de la indagación, el consenso de lo diverso, sin pretender eliminarlo o desconocerlo. En consecuencia, los derechos humanos de los que gozan todos en la comunidad universitaria, se concretan en libertades de diferencialidad, opinión, comportamiento, ideas políticas e intereses culturales (Morin, 2000, pp. 79-86).

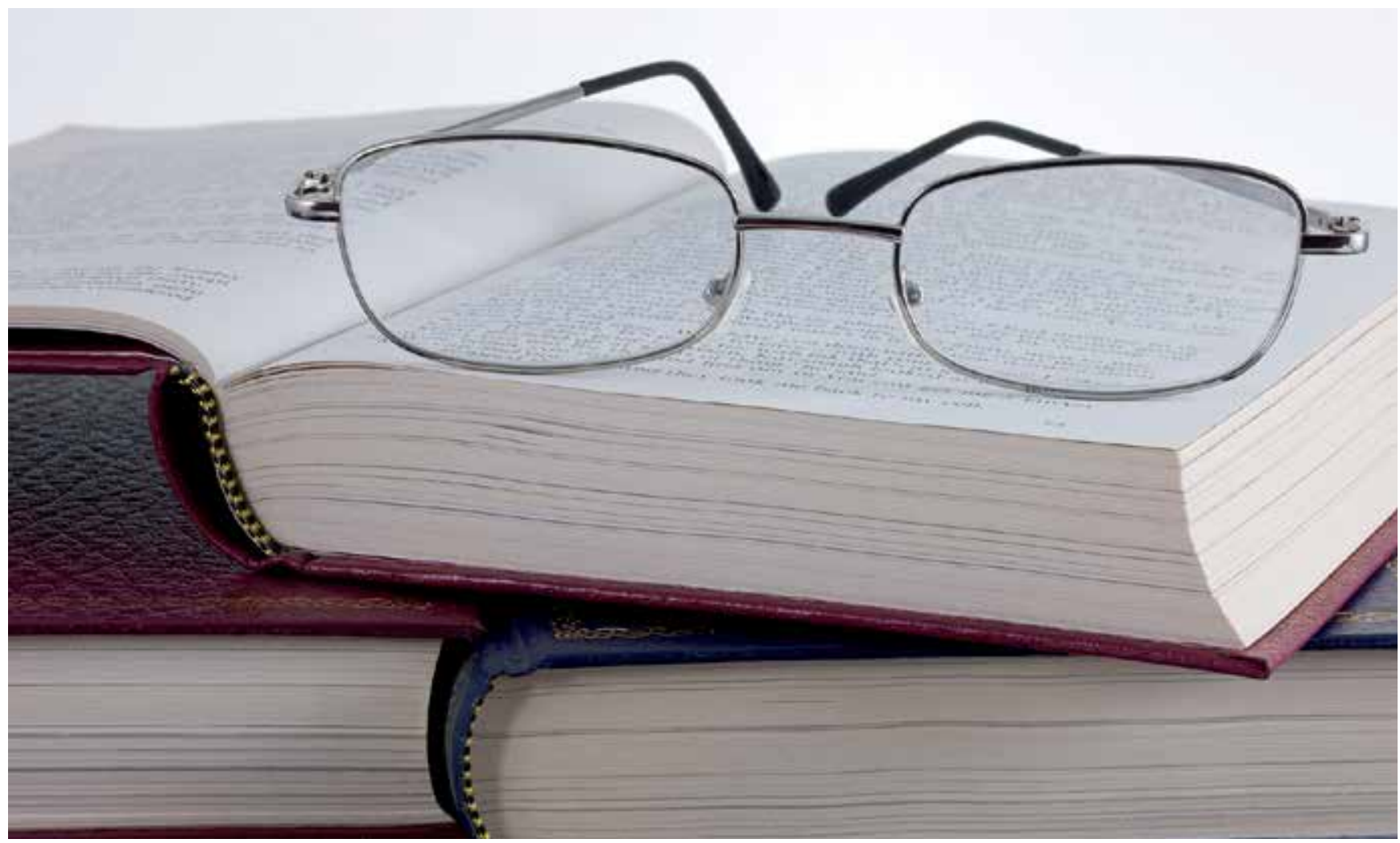




\section{TABLA 1.Pedagogía Responsivo-Comprensiva Personalizante}

\begin{tabular}{|c|c|c|c|}
\hline Niveles de significación & Preguntas y procesos & Insight & Capacidades \\
\hline $\begin{array}{l}\text { Nivel: Experiencia } \\
\text { sensible - empírico }\end{array}$ & $\begin{array}{c}\text { ¿Qué es? Acopio de datos } \\
\text { Contacto sensible realidad } \\
\text { Memoria - percepciones - } \\
\text { sensaciones }\end{array}$ & $\begin{array}{l}\text { Exposición a la } \\
\text { realidad, mundo de } \\
\text { la vida } \\
\text { Insight directo }\end{array}$ & $\begin{array}{l}\text { Siente, recuerda, escucha testimonios, } \\
\text { problematiza situaciones. Se domina a sí } \\
\text { mismo, recopila evidencias, busca información, } \\
\text { se expone a la situación, problematiza, indaga, } \\
\text { dialoga, intercambia ideas, reacciona frente } \\
\text { a los acontecimientos. El aprendizaje en este } \\
\text { nivel es inmediato y circunstancial, adaptativo } \\
\text { y comportamental, en consecuencia es } \\
\text { una respuesta del repertorio instintivo a las } \\
\text { carencias, agresiones o necesidades; se hace } \\
\text { indispensable que los hechos se aborden no } \\
\text { de modo rutinario ni instrumental y que se } \\
\text { responda haciendo consciente los conflictos. }\end{array}$ \\
\hline $\begin{array}{c}\text { Nivel: } \\
\text { Intelectual - conceptual }\end{array}$ & $\begin{array}{c}\text { ¿Este hecho sí es así? } \\
\text { De lo concreto a lo abstracto, } \\
\text { de lo conocido a lo } \\
\text { desconocido } \\
\text { Conceptualizaciones - } \\
\text { formulaciones - categorías - } \\
\text { términos - teorías }\end{array}$ & Insight indirecto & $\begin{array}{l}\text { Utiliza teorías, conceptos y categorías } \\
\text { interpretativas. Formula preguntas en } \\
\text { contexto histórico. Concibe soluciones. } \\
\text { Disiente e identifica contradicciones. Sigue } \\
\text { pesquisas, conoce los derechos humanos y } \\
\text { conceptualiza, teoriza, interpreta. El riesgo } \\
\text { del entendimiento conceptual es que } \\
\text { se caiga en la argumentación chillona y } \\
\text { prescriptiva o se utilicen marcos conceptuales } \\
\text { predeterminados, por tanto, es indispensable } \\
\text { que se llegue a la narración interpretativa } \\
\text { y autobiográfica. Al soporte científico. Se } \\
\text { evidencian los paradigmas. }\end{array}$ \\
\hline
\end{tabular}

Establece comparaciones, pondera y juzga razonablemente. Contextualiza, toma decisiones responsables y libres. Interpreta, disiente, elige, decide, respeta otras

Nivel: Valoraciones comparativas Reflexivo - crítico juicios - evidencias - contra evidencias - juicio en contexto
Insight reflexivo perspectivas. Interioriza, flexibiliza juicios, es razonable. El propósito dialógico de la reflexión es inducir el cambio, la toma de conciencia a nivel crítico y la expresión del deseo de transformación. La ética deliberativa induce a sopesar los juicios y a buscar el bien común. Se contrastan los modelos mentales.

Decide, elige, se compromete y actúa con base en la ética. Delibera e integra decisiones al proyecto de vida. Obra con autenticidad y autonomía. Se hace cargo de la realidad de sí mismo, de los otros y

Nivel:

Ético - deliberativo
¿Qué implica esto para mí? Toma de decisiones - elección compromiso - acción
Insight deliberativopráctico de la sociedad. Relaciona ética, derecho y política, propone soluciones alternativas, se implica en ellas, se compromete, lidera procesos de transformación democráticos. La autotransformación y el compromiso creativo es la expresión del vínculo ético con la realidad. Se supera lo rutinario e ineficaz. 


\section{Conclusiones}

Enfrentar la crisis de la universidad, circunscrita en la crisis de la razón moderna ${ }_{121}$, además de lo analizado desde el inicio de este artículo, demanda garantizar el diálogo crítico entre las racionalidades ${ }_{122}$, con prelación en el sujeto ético-político ${ }^{123}$, y en la investigación sobre las necesidades de este como individuo y colectividad Ilamados a transformar su ethos sociocultural y democrático ${ }^{124}$.

Además, posibilita hacer del desarrollo humano integral (Gómez, 2003), el marco de acción para el despliegue, potenciación y construcción de capacidades y competencias que concreten los talentos y derechos de las personas, con apertura crítica y dialógica, que reconozca las necesidades del contexto, interdisciplinarice el análisis, y ofrezca respuestas transdisciplinares y personalizantes.

121 El planteamiento acerca de la crisis de la modernidad y de la sobrevivencia de ésta, se puede hacer desde la "retórica dura" o desde el "enfoque narrativo"; lo importante es que el discurso requiere de un sujeto más reflexivo y consciente. (Agnes, 2000, Historia y futuro. ¿Sobrevivirá la modernidad? Barcelona: Ediciones Península). También, Héller Agnes y Feher Ferenc (1998), Políticas de la postmodernidad. Barcelona: Ediciones Península.

122 Algunos se plantean la necesidad de una nueva ilustración en la cual la integración entre las racionalidades sea posible desde la búsqueda de la libertad del sujeto, y que la crítica a la desviación de la racionalidad tecno-científica no desconozca sus aportes al bienestar humano, sino el uso manipulador que desde el poder se hace de lo económico-tecnológico. (Beck, 2002). La comparación entre la modernidad sólida y la modernidad líquida, utilizada por Zygmunt Bauman (2015), metáfora por medio de la cual analiza el desarrollo de la modernidad en todas sus etapas, desde la modernidad inicial, industrial, crítica hasta la modernidad irreflexiva y posmoderna contribuye a entender el impacto de estos procesos en los modelos educativos subsecuentes, el efecto en la construcción de la identidad individual humana, en el resquebrajamiento de las relaciones intersubjetivas, en la tendencia a la homogenización sociocultural, y sobre todo en la "fuga" del estado frente al desencanto provocado por los efectos dañinos de los mitos del "progreso infinito", del individualismo narcisista, de la globalización neoliberal, entre otros.

123 La filósofa es un claro ejemplo de la opción ético-política en situaciones de máxima inhumanidad. Atreverse a poner en tela de juicio y a someter a crítica lo que para algunos era inabordable desde la filosofía, la hace referente obligado, dado el empeño de transformación del ethos social-cultural desde la formación "nueva" y personalizante para la convivencia en paz (Arendt, 2002).

124 Hay tantos sentidos de modernidad cuantos interesados haya en usarlos, pero queda en claro que a la tripartición de la racionalidad hay que confrontarla desde la complejidad de los problemas que siempre serán reales, socio-culturales y discursivos (Latour, 2007).
Fortalecer la responsabilidad política, el liderazgo incluyente en favor de la igual, la equidad y la defensa de los derechos humanos, especialmente el derecho al conocimiento en todas sus posibilidades, implica para la universidad conocer el contexto local, regional y nacional a fin de que diagnosticadas las necesidades de las personas, e indagados los planes de desarrollo correspondientes, la propuesta formativa institucional sea pertinente y contribuya a la transformación de las condiciones de vida menos humanas en condiciones de vida más humanas, tanto de los individuos como de las colectividades.

La mayor riqueza para las personas "es ser ellas mismas a plenitud", es decir, con el aprovechamiento pleno de sus capacidades; por consiguiente, estas personas son la "más grande riqueza humana" para las sociedades, incomparables con ningún otro valor. Sin embargo, paradójicamente algunos sistemas educativos en lugar de capacitar, incapacitan y en lugar de humanizar, deshumanizan, casi siempre como consecuencia del irrespeto y la violencia cotidiana contra la dignidad, la diversidad y los derechos de las personas.

Para afrontar semejantes retos se requieren nuevos docentes capaces de integrar comunidades de aprendizaje en red, de hacer de la investigación transdisciplinar (Uribe, 2012) una alternativa viable de polidocencia y de impacto en el medio. A la holgura humana del docente le debe corresponder la idoneidad científica (Ibarra, 1999; Díaz, 1999) y la calidad pedagógica que incentive en los estudiantes el empeño "por ser más y mejores seres humanos". La crisis del sistema universitario amerita una nueva docencia ${ }^{125}$.

El contenido, el diseño y la gestión curricular demandan ser replanteados en coherencia con el modelo de desarrollo humano integral por

125 Además de los estudiantes, los docentes son los determinantes de la calidad humana y científica de la formación que imparte la universidad. Todo programa de formación que propicie su cualificación es poco para los efectos positivos que una buena práctica docente tiene en la vida de los estudiantes (Bain, 2006). 
capacidades y competencias, el enfoque personalista-confesional, y la decisión de garantizar la pertinencia del mismo con las necesidades locales, regionales, nacionales y globales de la sociedad.

Por consiguiente, también los modos de dirección, administración y gestión, en coherencia con la naturaleza y misión de la universidad y los retos de la crisis por la que atraviesa la universidad, debe ser menos burócrata, menos ritualista, más participativa, horizontal, y generadora de desarrollo humano.

\section{Reflexiones finales: La respuesta de la iglesia}

En lo concerniente a la crisis de la modernidad, la doctrina social de la iglesia católica detecta algunas de sus posibles causas en sus mitos fundacionales $y$, también en la ruptura de esta con los sujetos, la cotidianidad y las expectativas de realización integral de las personas; además propone soluciones que, a su juicio, contribuyen a la dignificación de las personas, a la concreción de sus derechos y al desarrollo humano integral de los sujetos.

Al respecto, en la primera parte de la encíclica Mater et magistra, dedicada por Juan XXIII (1961) a subrayar la contribución de la Rerum novarum de León XIII y de los papas posteriores a la doctrina social de la iglesia, Ilama la atención sobre los efectos contradictorios de la racionalidad modernista, posibilitadora de la era industrial y del liberalismo económico que, aunque en algo contribuyen a mejorar las condiciones de vida de algunos trabajadores, explotan a la mayoría, atentan contra la dignidad del trabajo, y no propician al desarrollo humano integral (Rerum novarum, 10-26). La Mater et magistra (59-68) subraya el florecimiento de las relaciones interhumanas y el despliegue del potencial de "afiliación" de las personas, que propicia la era moderna, pero también, alerta acerca de los riesgos que corren los sujetos de ser presa fácil de la manipulación de los poderes que propagan la idea de que "progreso es civilización". Juicio con el cual coincidirá más adelante Nussbaum, en lo que atañe a la eclosión del mito del progreso continuo (2012, p. 54).

En cuanto a la "capacidad de control sobre el propio entorno material", Nussbaum (2012, p. 54) acentúa el carácter de concreción del derecho de autonomía; en igual sentido lo hace la Mater et magistra (pp. 68-72). Sin embargo, aunque la encíclica lamente la situación infrahumana de un número incalculable de trabajadores, y la disculpe achacando el hecho al poco desarrollo de la economía industrial, no alcanza a evidenciar que esto resulta del maridaje contradictorio entre individualismo y utilitarismo liberal capitalista. Aun así, invita a vigilar y procurar que el desarrollo económico avance aparejado con el desarrollo social (Mater et magistra, p. 73). Más adelante la Mater et magistra (p. 79) hace hincapié en las obligaciones del Estado y de los poderes públicos de propiciar las condiciones básicas que faciliten el desarrollo integral de las capacidades de las personas. Se constata desde el inicio hasta el final del documento pontificio el valor que se otorga al ser humano, en cuanto fin en sí mismo (Mater et magistra, pp. 245-246).

En lo atinente a la educación como acción social la Mater et magistra (pp. 226-229) insiste en la coherencia que debe haber entre la teoría y la práctica, los fines que se trazan, lo que se dice que se es y lo que efectivamente se hace. Como se explicará en su momento, la propuesta pedagógica del "ver, juzgar y actuar", eje de la acción social educativa (Mater et magistra, p. 236) se resignificará como alternativa de generación de capacidades humanas.

En continuidad con la doctrina social precedente, la encíclica Pacem in terris de Juan XXIII (1965) se ocupa de los derechos y deberes promulgados en la Carta Universal de los Derechos Humanos de las Naciones Unidas y los interpreta a la luz del principio dignidad de todos los seres humanos (pp. 8-34 y 63). En cuanto al "derecho a una existencia plena y a un nivel de vida 
decoroso" (pp. 11, 64), las coincidencias entre esta encíclica y la propuesta de capacidad "vida y salud física" de Nussbaum (2013, p. 53), saltan a la vista, también en cuanto a la necesidad de condiciones de alimentación, salubridad e higiene. Más adelante al tratar el texto eclesial del "derecho a la verdad y a la cultura" (p.13) acentúa la urgencia de que los ciudadanos cuenten con las condiciones para acrecentar sus "capacidades, su talento y su experiencia". Aún más, considera que el "bien común abarca a todo el hombre" de manera integral (p. 53), y por consiguiente todas las"condiciones sociales que permitan a los ciudadanos el desarrollo expedito y pleno de su propia perfección" (p. 58) ${ }^{126}$.

En relación con el desarrollo integral de las capacidades humanas, la Populorum progressio de Pablo VI (1967), diferencia entre el desarrollo de las potencialidades, talentos y "carismas" de las personas y el desarrollo de las condiciones socio-económicas y culturales de los colectivos humanos, responsabilidad de las políticas gubernamentales, pero deja en claro que si bien las condiciones favorecen el desarrollo humano de las personas, a estas les compete poner al servicio del bien "común" todas sus capacidades. Además, considera que de acuerdo con el "humanismo trascendental" en que se fundamenta, el desarrollo auténtico

126 En relación con la inclusión de los derechos humanos en el preámbulo de la carta política de los Estados, la Pacem in terris se adelanta en décadas al adoptarlos dentro de la doctrina social de la Iglesia, y al sugerirlos para las cartas constitucionales de aquellos (P.T.,75). De otra parte, la misma Iglesia al propiciar el diálogo, el análisis crítico y el debate maduro adaptado a las circunstancias de los interlocutores, con visión plural y respeto por la dignidad de las personas, exige excluir la "condenación apriorística, la polémica ofensiva y habitual y la futilidad de la conversación inútil" (Pablo VI, 1964, Ecclesiam suam, pp. 72-74; y Populorum progressio, p. 73), a fin de que se encuentre la "verdad" guiada por la caridad, la inteligencia y el amor (Ecclesiam suam, p. 76), por medio de la claridad que facilita la comprensión, la paciencia que invita a la búsqueda generosa, la confianza que excluye el egoísmo, y la prudencia que responsabiliza adecuando la misión de la Iglesia a la vida de los hombres en un "tiempo dado, en un determinado lugar, en una cultura concreta, en una situación social particular" (Ecclesiam suam, pp. 75-81). Así, "donde quiera que el hombre busca comprenderse así mismo, y al mundo, podemos unirnos a él" (Ecclesiam suam, pp. 91-107). Exhortación que recoge Fides et Ratio (p. 1) al considerar que "conocerse a sí mismo" es rasgo identitativo humano, expresión de la capacidad especulativa de la razón que demanda trascendencia y sabiduría (Fides et Ratio, pp. $2-5,6-9,25)$. o completo debe "abarcar a todo el hombre, y a todos los hombres"127; en consecuencia, señala como "primer responsable y artífice de su propio desarrollo" a la misma persona, en tanto "ser humano concreto", situado en un contexto particular, en un "aquí y ahora" específicos que le impelen a promover su propio progreso, a crecer y a germinar en aptitudes y cualidades de las cuales es artífice. En este sentido, buscar el propio desarrollo no es solo un derecho, es ante todo un deber personal (Populorum progressio, pp. 12-16) ${ }^{128}$.

127 Humanismo pleno que hay que promover como "desarrollo integral de todo hombre y de todos los hombres", un humanismo que lanza al hombre a la permanente superación (Populorum progressio, p. 42). Concepción liderada por L. J. Lebret, O.P., desde la década del cuarenta (Dinámica concreta del desarrollo, 1969), y cuyos aportes se recogen en la Populorum Progressio, pues al decir del dominico: "se tenía el sentimiento de que era posible dirigir una evolución técnica y económica en sentido favorable a los hombres, si se empezaba por estudiar la realidad compleja que se debe dominar, si se elabora una doctrina y si se creaban las fuerzas colectivas deseosas de aplicarla" (Populorum Progressio, p. 10), método conocido como "ver, juzgar y actuar"; pero, solo si asumen las situaciones en toda su complejidad y vínculo, llamándolas por su nombre, pues el hambre no es solo desnutrición ni las epidemias masivas enfermedades carenciales (Populorum Progressio, p. 22). La encíclica se promulgó en el momento en que el término"desarrollo" era una palabra mágica relacionada con el nivel de consumo de los países ricos y con la ruptura con tradiciones no progresistas. La alternativa frente a las miradas reduccionistas, afirma Lebret, es procurarse una mirada total de lo real, compleja, polivalente o transdisciplinaria, ética, y sobre todo relacionadas con el optimum humano (Populorum Progressio, pp. 23-25), en definitiva con los valores. En conclusión, se debe examinar de nuevo la noción de desarrollo, dado que: "algunos autores adolecen de cortedad, aprisionados por la teoría del poseer y por la extensión de la posesión, cuando en realidad habría que subordinarlo todo a ser-más y elaborar una teoría y una praxis del ser-más que comprendiese la utilización civilizadora del poseer" (Populorum Progressio, p. 25). Además, a juicio del experto el desarrollo terminará en fracaso si no se rescata su poder civilizador, se atiende a las necesidades, potencialidades y posibilidades humanas $\mathrm{o}$, por el contrario se deja al capricho del ansía de poseer (Populorum Progressio, p. 31). El desarrollo auténtico de todo el hombre y de todos los hombres, es el propósito de la teoría educativa basada en el crecimiento y acrecentamiento de las capacidades y las competencias.

128 Considera la Populorum progressio que el verdadero desarrollo es aquel que promueve el paso de "cada uno y de todos de condiciones menos humanas a condiciones más humanas de vida" (pp. 19-20). Después de listar aquello que se considera menos humano, también se citan aquellas condiciones consideradas más humanas: "remontarse de la miseria a la posesión de lo necesario, vencer las calamidades sociales, adquirir nuevos conocimientos $y$ cultura... fortalecer el sentido de cooperación y austeridad, entre otros (Populorum progressio, p. 21). Después de llamar la atención sobre los peligros del capitalismo rentista, contradicción de la modernidad industrial referida con anterioridad, cita los daños de la economía rentista y de la instrumentalización de las personas a través del trabajo; dado que todo programa de producción y economía debe apuntar a la equidad, al progreso ético y espiritual (Populorum progressio, pp. 22-41, 56-58). La propuesta formativa 


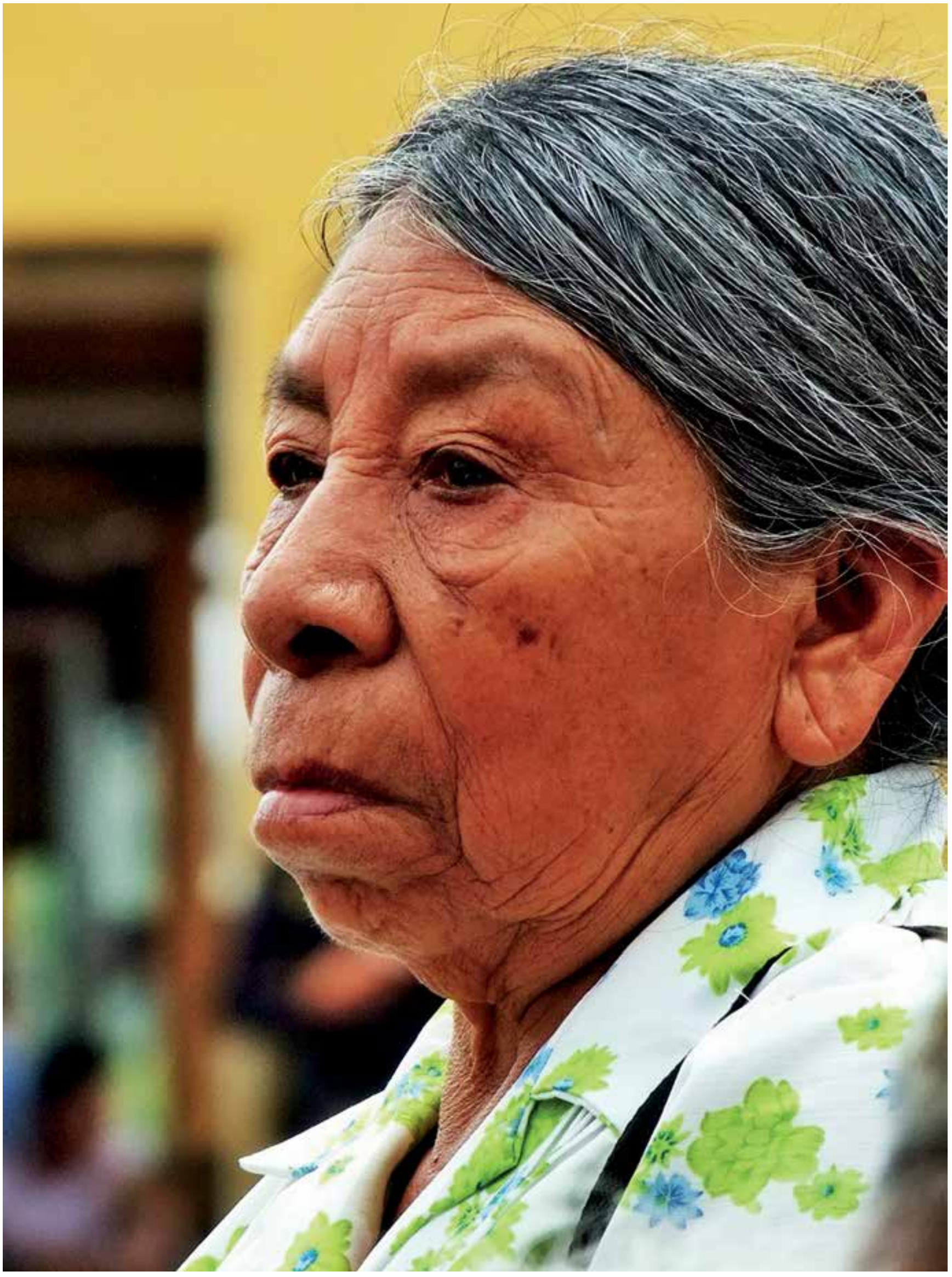


Asimismo, en la constitución pastoral sobre el mundo actual, Gaudium et spes (1965), el Vaticano II constata el nacimiento de un nuevo humanismo basado en la autonomía y la responsabilidad humanas, fruto de los cambios promovidos por el desarrollo de las ciencias exactas, la psicología, las ciencias históricas, el urbanismo y la industrialización, es decir, generado por la modernidad. Al respecto, se pregunta cómo educar de manera que se favorezca el diálogo entre la tradición y la cultura científica, entre cultura clásica y especialización actual, sin caer en humanismos reduccionistas (Gaudium et spes, pp. 53-56), pues frente a los nuevos cambios y problemas, apremian nuevos análisis y nuevas síntesis (Gaudium et spes, p. 5). Sobre todo, en lo concerniente el campo de las relaciones humanas, se espera que las nuevas dinámicas de socialización generen nuevos procesos de madurez "auténticamente personalizadores" (Gaudium et spes, p. 6). Se insiste en el papel que juegan las relaciones "intersubjetivas" en los procesos de construcción de la identidad de las personas ${ }^{129}$; así como en la preponderancia del "hacer humano" para la transformación, perfeccionamiento, crecimiento y promoción de estas; vínculos y praxis que le permiten cultivarse hasta "el desarrollo pleno de su personalidad"130.

basada en el desarrollo humano integral de capacidades y competencias, propicia una respuesta más atenta, más activa, más participativa y democrática a las necesidades de verdad, justicia, restauración y no repetición, en el proceso de post-conflicto (Populorum progressio, pp. 76 y 85 ).

129 Cambios que ponen en jaque los mecanismos de "regulación y control" tradicionales o heredados de la primera modernidad, y que se manifiestan en el espíritu crítico de los jóvenes (Gaudium et spes, p. 7). Pero, es al analizar los desequilibrios en el mundo moderno que la "constitución sobre la iglesia" capta las llamadas "crisis de la racionalidad moderna", es decir las contradicciones engendradas desde el inicio y evidentes en la etapa del "capitalismo desorganizado" entre: ética y conocimiento teórico, entre eficacia técnica y cognoscitiva, y razón práctica, entre intereses individuales y bien común (Gaudium et spes, p. 8). De las aspiraciones formuladas en el número nueve (Gaudium et spes, p. 9) de este documento se infieren propósitos relacionados con la promoción del desarrollo humano integral, tal y como se formulan en las capacidades básicas. Pero, sobre todo de la dignidad de la persona humana (Gaudium et spes, pp. 12-17), de la necesidad de promover el bien común, el respeto, y la igualdad entre las personas (Gaudium et spes, pp. 26-29).

130 Con respeto por la autonomía de todas las ciencias, favoreciendo el diálogo transdiciplinar con la teología, la moral y los nuevos conocimientos, pero "respetando la libertad de investigación,
Frente a la gravedad de la crisis cultural y ecológica la Iglesia Católica (Laudato Sii, 2015), propone como respuesta la adopción de procesos educativos que contribuyan a la construcción de una "nueva ciudadanía"131. Los lineamientos educativos de Laudato Sii (2015) ${ }^{132}$

de pensamiento y de hacer conocer humilde y valerosamente su manera de ver en los campos que son de su competencia" (Gaudium et spes, pp. 35, 41 y 62). Pues, como afirma la Fides et Ratio (pp. 24-35, 64-79), retomando a Aristóteles: "todos los hombres desean saber" y por consiguiente se orientan a desear la verdad, a fin de darle sentido a la vida según las culturas, las preocupaciones cotidianas, y las escuelas de pensamiento que les aporten a la búsqueda de sentido de vida. El Documento de Puebla (1979) producto de la III Conferencia General del Episcopado Latinoamericano, hace eco de los documentos del Vaticano II y acentúa algunos puntos con miras a que la educación se convierta en eje de justicia y equidad, pues la "situación de pobreza de muchos de nuestros pueblos está relacionada con los procesos educativos", con el analfabetismo, la deserción escolar, y la imposibilidad de acceder a un empleo cualificado (D.P., 1014), situación que se acentúa en los pueblos originarios y ancestrales (D.P.,1015); por la explosión demográfica (D.P., 1016) o por qué se identifica la educación católica con educación para la élite (D.P., 1019). En sintonía con la Gaudium et spes (pp. 53-61), el documento de Puebla (1024) recuerda la naturaleza y fin cultural de la educación, por ser ante todo humanizadora y personalizante, proceso que se desarrolla haciendo que fructifiquen el pensamiento y la libertad, la comprensión y la visión global de la realidad, la cultura, la sociedad y la historia. En este sentido la educación evangeliza y libera de manera integral (D.P., 1026), humaniza y personaliza (D.P., 1027), integra los valores cristianos a los procesos de transformación social (1028), forma la capacidad crítica y propende por la justicia (D.P., 1029), se centra en el sujeto formándolo para servir (D.P., 1030), es contextual y cristológica (D.P., 1031-1032), antropocéntrica, diferenciada, plural y respetuosa de las opciones personales (D.P., 1034), sistemática, dialógica, reflexiva y lugar privilegiado para debatir e integrar fe y razón (D.P., 1040, 1052-1053); para lograrlo es indispensable diagnosticar las necesidades, conocer los retos, enfrentarlos, capacitar los agentes, cualificar los recursos, y gestionarlos de manera participativa (D.P., 1046, 1054-1055); de no hacerlo en forma cualificada y permanente se sigue la deserción, la falta de empleo profesional y la frustración de los jóvenes (D.P., 1051) En cuanto evangelizadora se debe centrar en el testimonio, en la acogida de todas las personas y en el respeto "sobresaliendo por la seriedad científica, el compromiso con la verdad, la preparación de profesionales competentes, y por la búsqueda de soluciones a las crisis que vive la humanidad" (D.P., 1059). Por medio de procesos integradores entre lo humanístico y lo científico la universidad renueva y transforma la cultura con el testimonio del evangelio, a fin de que la sociedad sea más fraterna y justa; da cabida al diálogo inter y transdisciplinar, busca y construye la verdad con el aporte de todos, también con el aporte de los hombres y mujeres de buena voluntad que, aunque no crean o militen en otras confesiones, acepten el mensaje del amor cristiano, y se integran a la familia universitaria (D.P., 1061-1062).

131 Pues no es suficiente con acceder a la información cientíica ni con la toma de conciencia sobre la gravedad de los daños ambientales, hace falta desmontar el mito del progreso continuo y recuperar el "equilibrio ecológico consigo mismo, con los otros, con todos los seres vivos, con lo trascendente y "crear un ciudadanía ecológica". En consecuencia formar en la ética del cuidado, la solidaridad y la responsabilidad con la vida (Laudato Sii, pp. 209-215).

132 El giro hacia la antropología ecológica, además de plantear serios cuestionamientos a los enfoques metafísicos y especulativos 
recogen planteamientos hechos por científicos y pensadores sociales, así como por la doctrina social de la iglesia, y los trata de manera dialógica, incluyente e integrativa, en tanto corrientes que promueven la "ciudadanía ecológica" y que coinciden en la centralidad de la vida como eje articulador de la formación de las personas, la correlación simbiótica entre lo biológico, lo personal y lo socio cultural; la complejidad de la realidad que desborda toda pretensión racionalista y en la necesidad de superar el modelo instrumental expandido por la modernidad irreflexiva; así como en el agotamiento de la sociedad del mercado y la renta, incapaz de garantizar las condiciones de vida digna para la mayoría de los grupos humanos. También, enfatiza en la necesidad de adoptar cosmovisiones culturales incluyentes y respetuosas de la diversidad biológica, social y cultural ${ }^{133}$.

En síntesis, se trata de contribuir a la transformación del ethos cultural colombiano mediante la formación de una nueva ciudadanía "ecológica", como respuesta a las necesidades apremiantes de la sociedad actual, resignifican-

tradicionales, ahonda en las alternativas pedagógicas "inter-correlacionales" de cuño bio-psico-social. Y, amplía el concepto tradicional de "integralidad formativa", al mostrar como los contextos y las relaciones múltiples existentes entre naturaleza, sociedad e individuo, intervienen en la construcción de las dimensiones humanas, según el enfoque de "ecología integral" conformada por la ecología ambiental, socio-cultural y humana. Dicha encíclica concibe los contextos ecológicos como sistemas "vivos" simbióticamente relacionados, que conforman los mundos de sentido, sustento de la construcción de la identidad humana individual y colectiva. La pretensión colonizadora ejercida por la cultura del consumo, desconoce la riqueza de la diversidad cultural, y el papel que juegan los actores sociales en la generación, transformación y protección de esta y del bien común (L.SIl, No. 139-162).

133 El análisis efectuado propone la adopción del enfoque formativo ecológico para construir capacidades y competencias humanas, que superen los modelos educativos "de entrenamiento eficientista" adecuados al mercantilismo tecnócrata y a la expansión del mito del progreso indefinido, el individualismo y la conquista de la felicidad por medio del consumo. La creación de la "ciudadanía ecológica", es viable en la medida en la cual a través de la praxis personal y colectiva se construyan nuevos "habitus coherentes con la dignidad de las personas" (Laudato Sii, Francisco 2015, No. 209-2015, pp. 159-163). El formato ecológico del texto se desenvuelve con base en el principio de complementariedad entre "sentimiento estético espiritual, la bioética y el uso consciente de la razón científica", avanza desde el diagnóstico de la crisis subrayando los hechos problemáticos, los analiza desde la teología de la creación y la ética ecológica, y para la acción propone la ecología integral y el diálogo participativo, contexto de lo celebrativoespiritual. do la tradición humanista de la universidad que apunta al desarrollo humano integral por capacidades y competencias.

\section{Referencias}

Arendt, H. (2002). La vida del espíritu. Barcelona: Editorial Paidós.

Bain, K. (2006). Lo que hacen los mejores profesores universitarios. Valencia, España: Publicaciones Universidad de Valencia.

Bárcenas, A. (2010). La hora de la igualdad: brechas por cerrar, caminos por abrir. Santiago, Chile: CEPAL-ONU.

Bauman, Z. (2013). Sobre la educación en mundo líquido. Barcelona: Paidós.

Bauman, Z. (2015). Modernidad líquida. México D.F.: Fondo de Cultura Económica.

Bauman, Z., y Donskis, L. (2015). Ceguera moral. La pérdida de la sensibilidad en la modernidad líquida. Barcelona: Editorial Paidós.

Beck, U. (2002). Libertad o capitalismo: conversaciones con Johannes Willms. Barcelona: Editorial Paidós.

Beck, U., Giddens, A., y Lash, S. (2001). Modernización reflexiva política, tradición y estética en el orden social moderno. Madrid: Alianza Editorial.

Blumer, H. (1982). El interaccionismo simbólico: perspectiva y método. Barcelona: Editorial HORA S.A.

Brunner, J., y Hurtado, F. (2011). Educación Superior en Iberoamérica, Informe 2011. Santiago, Chile: Editores RIL.

Bustamante, G., Zubiría, S. y otros. (2002). El concepto de competencias II. “La moda de las competencias". Bogotá: Sociedad Colombiana de Pedagogía.

Bustamante, G. (2003). El concepto de competencia III. Bogotá: Sociedad Colombiana de Pedagogía.

CEPAL. (2010). La hora de la igualdad: brechas por cerrar, caminos por abrir. Santiago, Chile: CEPAL-ONU.

Misión de Ciencia, Educación y Desarrollo. (1996). Colombia: Al filo de la oportunidad. Santafé de Bogotá: Tercer Mundo Editores.

De Aquino, Santo Tomás. Summa Theologica. I - II, q.90 a.1 et q.91, a.2.

De Aquino, Santo Tomás. QQ.DD De Potentia, q. 9, a. 3:2.

Delors, J. (1997). La educación encierra un tesoro. Madrid: Unesco-Santillana.

De Sousa Santos, B. (2012). De la mano de Alicia. Bogotá: Siglo del Hombre Editores, Uniandes.

Díaz, M. (1999). La formación de profesores en la educación superior Colombia: Problemas, conceptos, políticas y estrategias. Bogotá: Instituto Colombiano para el Fomento de la Educación Superior.

Gadamer, H. G. (1997). Verdad y método, Vol. I, Vol. II. Salamanca, España: Editorial Sígueme.

Garay, J. (2002). Repensar a Colombia. Bogotá: PNUD, Universidad de los Andes. 
Gaviria, A. y otros. (2014). Cobertura y calidad de la educación superior en Colombia. En: Orozco, L. E. (Coord.). La educación superior: retos y perspectivas. Bogotá: Ediciones Uniandes.

Gómez, H. (Coord.). (2003). El conflicto, callejón con salida. Informe Nacional de desarrollo humano. Bogotá: PNUD.

González, P., y Roitman, M. (2006). La formación de conceptos en ciencias y en humanidades. Ciencias de la certidumbre y ciencias de la incertidumbre. México. DF.: Siglo del Hombre Editores.

Habermas, J. (1991). Escritos sobre moralidad y eticidad. Barcelona: Editorial Paidós.

Habermas, J. (1975). Problemas de legitimización en el capitalismo tardío. Buenos Aires: Ediciones Amorrortu.

Habermas, J. (1982). Conocimiento e interés. Madrid: Editorial Tauros.

Habermas, J. (1998). Facticidad y validez. Madrid: Editorial Throta.

Habermas, J. (2008). Conciencia moral y acción comunicativa. Madrid: Editorial Trotta.

Heller, A. (1984). Crítica de la ilustración. Barcelona: Ediciones Península.

Heller, A. (2000). Historia y futuro. ¿Sobrevivirá la modernidad? Barcelona: Ediciones Península.

Heller, A., y Feher, F. (1998). Políticas de la postmodernidad. Barcelona: Ediciones Península.

Hernández, C. A. (2000, abril). Ciencia, universidad e investigación. La universidad y la vigencia de la cultura académica. Revista Nómadas, (12), 225-232.

Hernández, J., Delgado, Á. y otros. (2013). La universidad cercada, testimonios de un naufragio. Barcelona: Editorial Anagrama.

Ibarra, O. (1999). Formación de profesores de la educación superior, programa nacional. Bogotá: ICFES.

Latour, B. (2007). Nunca fuimos modernos. Buenos Aires: Siglo Veintiuno Editores.

Levinas, E. (2015). Escritos inéditos 2. Palabra y silencio y otros escritos. Madrid: Editorial Trotta.

Lonergan, B. (1999). Insight. Estudio sobre la comprensión humana. Salamanca: Ediciones Sígueme.

Ministerio de Educación Nacional. (1992). Ley 30 de Educación Superior. Santa fe de Bogotá.

Morin, E. (1999). Los siete saberes necesarios para la educación del futuro. Bogotá: Unesco-MEN.

Morin, E. (2011). La vía para el futuro de la humanidad. Barcelona: Editorial Paidós.

Nussbaum, M. (2000). Las mujeres y el desarrollo humano. Barcelona: Herder.

Nussbaum, M. (2005). El cultivo de la humanidad. Barcelona: Paidós.

Nussbaum, M. (2007a). Las fronteras de la justicia. Barcelona: Paidós.

Nussbaum, M. (2007b). Sentimientos morales y el enfoque de capacidades. Claves de razón práctica, (169), 28-35.
Nussbaum, M. (2010). Sin fines de lucro. Buenos Aires: Katz Editores.

Nussbaum, M. (2012). Crear capacidades. Barcelona: Paidós.

Nussbaum, M. (2013). La nueva intolerancia religiosa. Barcelona: Paidós.

Nussbaum, M. (2014). Emociones políticas. ¿Por qué el amor es importante para la justicia? Madrid: Paidós.

OCDE y Banco Mundial. (2012). La educación superior en Colombia. Evaluación de la política nacional. Bogotá: OCDE-Banco Mundial.

ONU. (2010). Informe Homenaje al modelo de desarrollo humano 20 años. En consideración a los aportes de Mahbub UI Haq y Amartya Sen. Nueva York: ONU.

Orozco, L. E. (1999). La formación integral: mito y realidad. Bogotá: Ediciones Uniandes.

Orozco, L. E. (2001). Bases para una política de Estado en materia de educación superior. Bogotá: MEN-ICFES-ASCUN.

Orozco, L. E. (2014). Tendencias de las políticas públicas en materia de educación superior. En: Orozco, L. E. (Coord.). La educación superior: retos y perspectivas. Bogotá: Ediciones Uniandes.

Pinker, S. (2006). Sobre la naturaleza humana. Claves de razón práctica, (167), 28-35.

Korthagen F.A.J., \& Kessels, J.P.A.M. et al. (1999). Theory and Practice: Changing the Pedagogy of Teacher Education. Educational Researcher, 4(28), 4.

Revista Internacional Magisterio. (2003, enero-febrero). El debate sobre las competencias, (1). Editorial Magisterio.

Revista Internacional Magisterio. (2003, junio-julio). Lineamientos y estándares curriculares, competencias, logros e indicadores. ¿Cómo armar el rompecabezas?, (3). Editorial Magisterio.

Revista Internacional Magisterio. (2004, marzo). Competencias Lectoras, (7). Editorial Magisterio.

Revista Internacional Magisterio. (2006, agosto-septiembre). De las competencias laborales a las competencias productivos, (22). Editorial Magisterio.

Schillebeeckx, E., O.P. (1995). Los hombres relato de Dios. Salamanca: Editorial Sígueme.

Sedano, J.J. (2002). Pedagogía de la respuesta. Testimonium Veritatis, 7. Bucaramanga: Convento Cristo Rey-Usta.

Sen, A. K. (2011). ¿Equivale el crecimiento económico a la calidad de vida? Revista Claves de Razón Práctica, (213), 4-7.

Terrén, E. (1999). Educación y modernidad. Entre la utopía y la burocracia. Barcelona: Ánthropos. Editorial.

Uribe, C. (Comp.-ed.). (2012). La Interdisciplinariedad en la universidad contemporánea. Bogotá: Editorial Pontifica Universidad Javeriana.

Wasserman, M. (2015, mayo). La punta del iceberg y la casita en el aire. El Tiempo. Bogotá. Recuperado de http:// www.eltiempo.com/opinion/columnistas/la-punta-deliceberg-y-la-casita-en-el-aire-moises-wasserman-columnista-el-tiempo/15847295

Zubiri, X. (2004). Inteligencia sentiente. Madrid: Tecnos. 